\title{
مواقع التواصل/لاجتماعيواتتهاكاتالكمصوصية:
}

\section{السنابشات/الفيس بوكنموذجًا}

(دساسةميدانيةعلى عينةمن متابعي السنابشاتوالفيس بوكن الجمهوه المري)

$$
\text { د / سالي سعد جوده ابراهيم }
$$

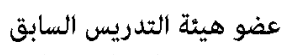

بقسم الصحافة والإعلام بكلية الآداب والعلوم الإنسانية، جامعة جازان، المملكة العربية السعودية

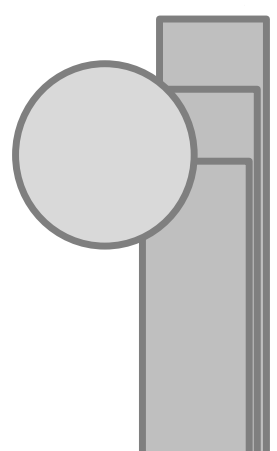

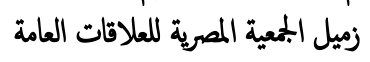

منسقة بشعبة العلاقات العامة بمتندى الأصالة والتجديد في بحوث الإعلام العربية

المقدمة:

إن المتأمل للعالم يجد التطور الهائل في كافة مجالات الحيـاة ولاسـيما فـي مجـال

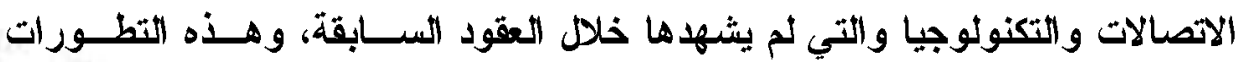

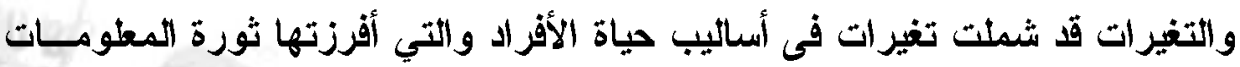

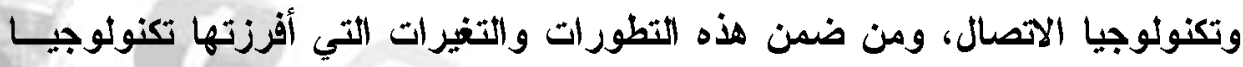

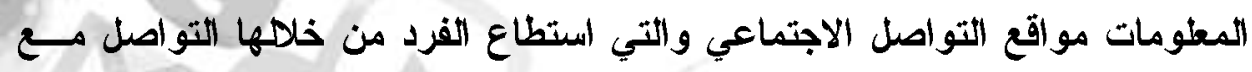

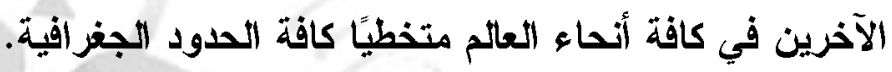


وكان لافتا كيف حازت مواقع التو اصل الاجتماعي ومن بينها السناب شــات و الفـيس

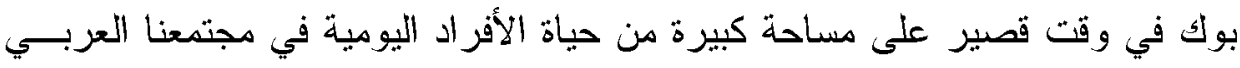

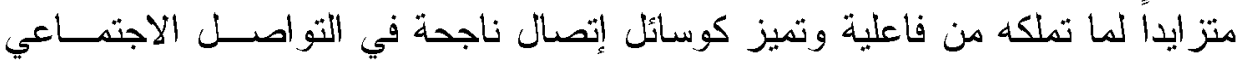

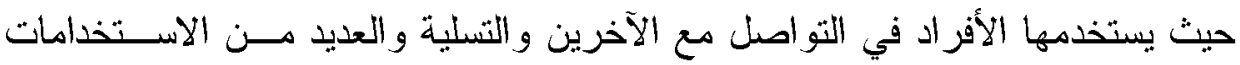

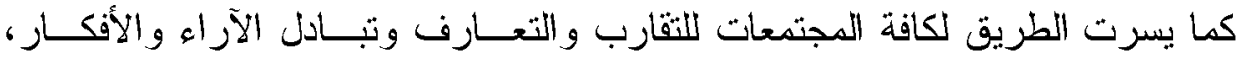

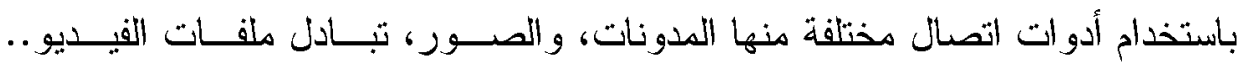

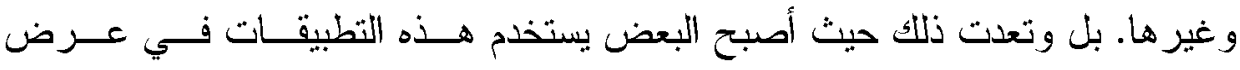

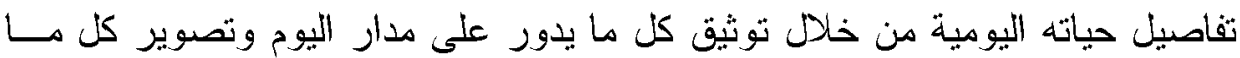

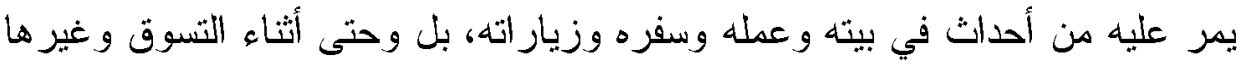

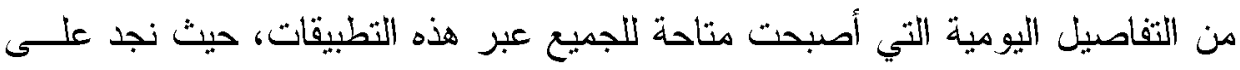

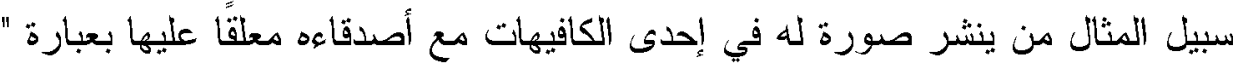

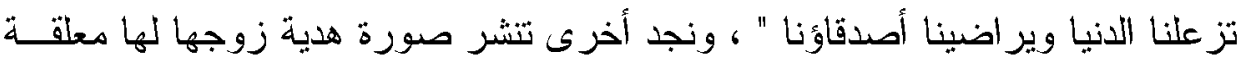

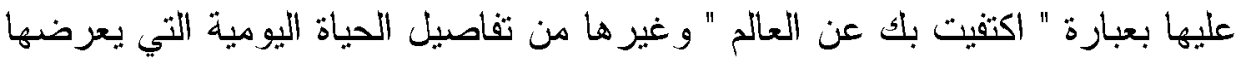

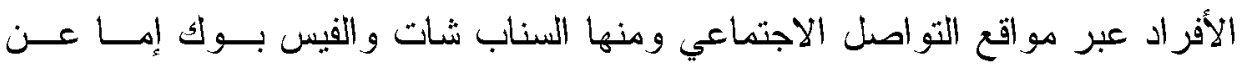
طريق خاصية (story) أو من خلا (post )

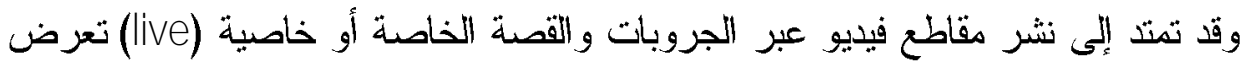

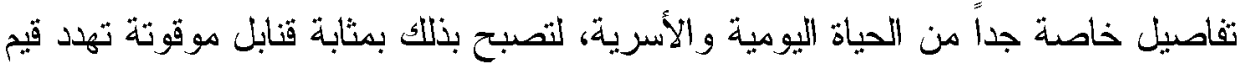
المجتمعات بل ويتعداها إلى انتهاك الخصوصية لأفراد هذه المجتمعات.

علاوة على ما سبق نجد أن مستخدم مو اقع التواصل الاجتماعي ومنها السناب شــات و الفيس بوك يكثف بإرادته عن كل ما بتعلق بحياته الشخصية في الفضاء الإلكتروني

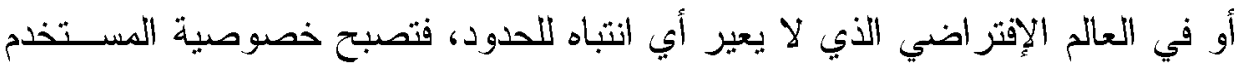

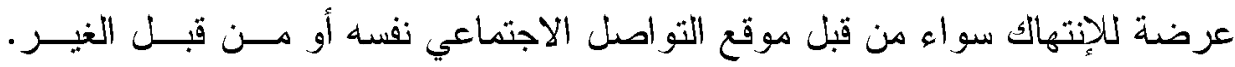

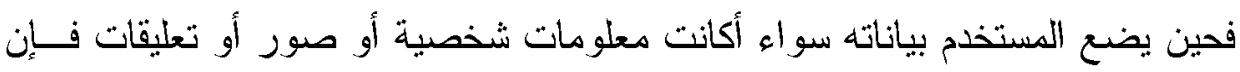
هذه المواقع ومن خلال شروط استخدامها والتي وقع عليها المستخدم تقوم بحفظ كـلـل 


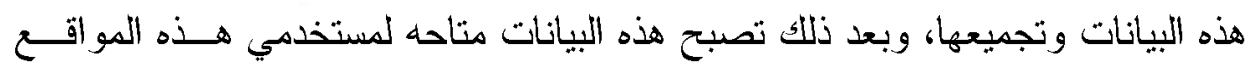
حسب اعدادات كل موقع، ويترتب على ذلك خطورة وصول أبي مستخدم إلى بيانـات

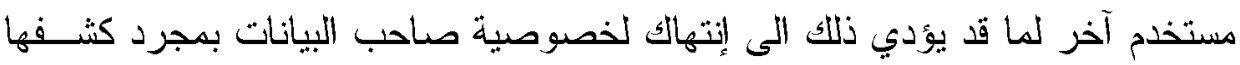

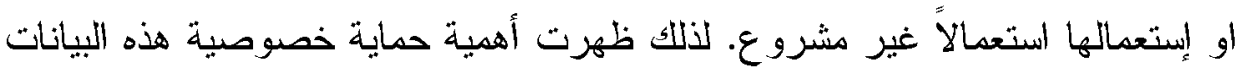
على الصعيد الدولي او على الصعيد المحلي '. بالإضافة إلى أن فالمستخدم في مواقع التواصل الاجنماعي ، الأبي يغرقه كم هائل من

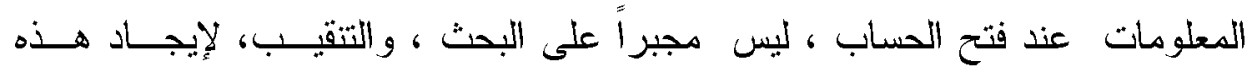

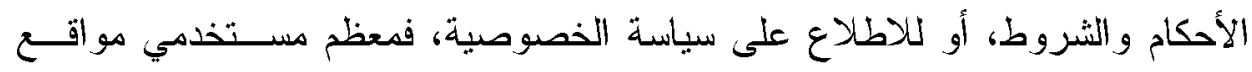

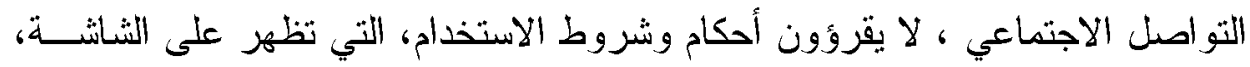

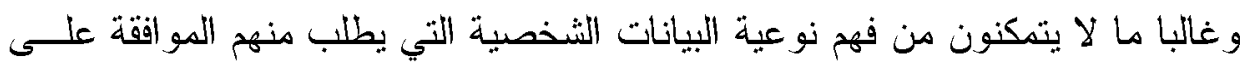

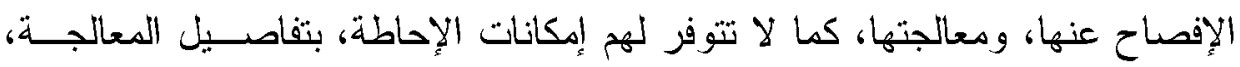
وتأثيرها عليه، سواء عندما يوافقون على شروط استخدام مواقع التواصل الاجتماعي لتوني

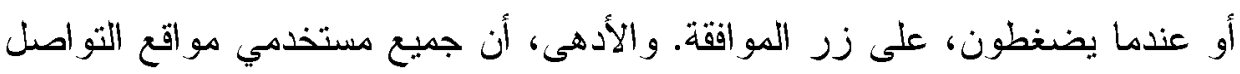

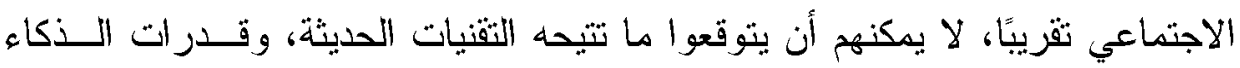

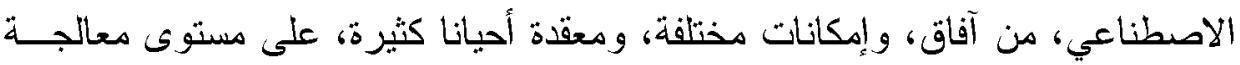

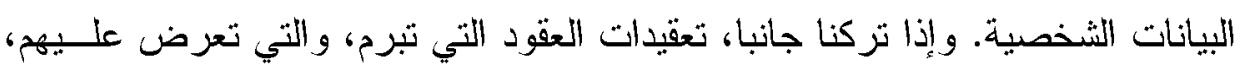

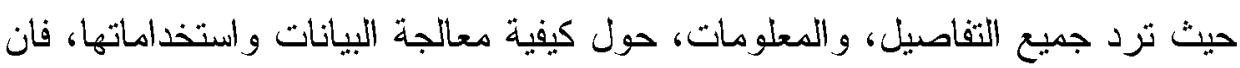

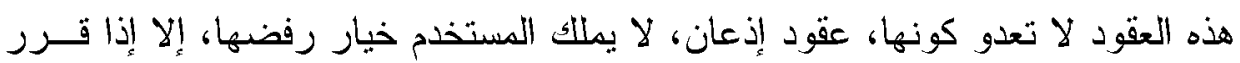

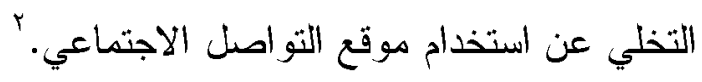

'رائد محمد فليح النمر ( : " حماية خصوصية مستخدمي مواقع التواصل الاجتماعي على ضوء التثريعات في مملكة البحرين ", 207-2021 20available on line @ https://cutt.us/NW8z9 , access on

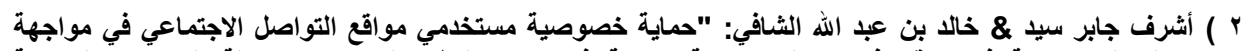

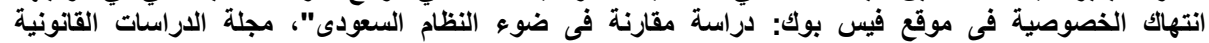

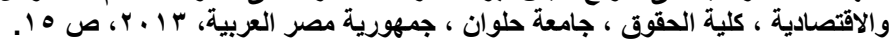


وبناءٌ على ماسبق أصبح من الضروري دراسة أتشكال وصور انتهاكات الخصوصـية

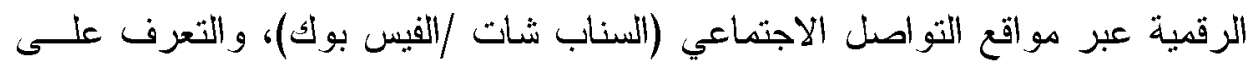
إتجاهات الجمهور العربي تجاه تلك الانتهاكات وأسباب استمرار انتشار ها والإجراءات الو اجب اتباعها للحد من تلك الانتهاكات.

\section{أولاً: مشكلة الدراسة وأهميتها}

\section{(أ) مشكلة الدراسة:}

إن مو اقع التو اصل الاجتماعي مثل السناب شات و الفيس بوك قد أصــبحت جـزءةًا لا لا يتجز أ من الحياة اليومية لمعظم مستخدمي الإنتزنت كماغيرت أسلوب حياة المستخدمين

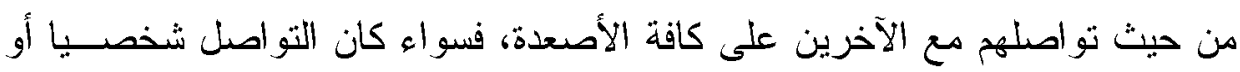

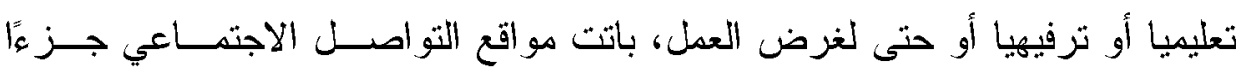

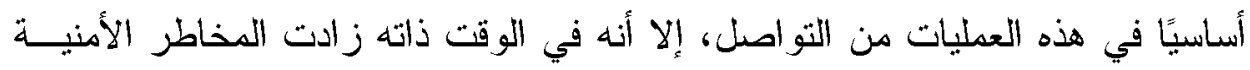
ومخاطر انتهاك الخصوصبة التي تحف مستخدمي هذه الثبكات.

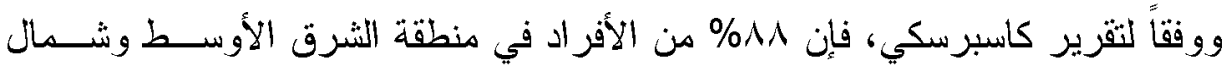
إفريقيا يستخدمون هذه المنصـات، التي تتيح في مقابل الحصول على بعـض البيانـات

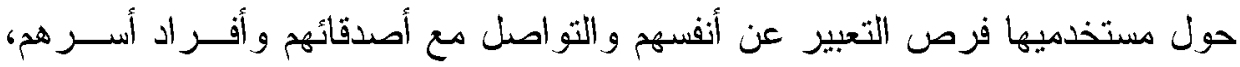
وكذلك مطالعة الأخبار و الأفكار و التوجهات، أينما كانو اوفي أبي وقت.

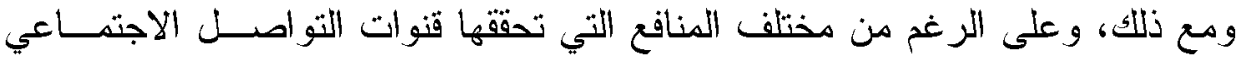

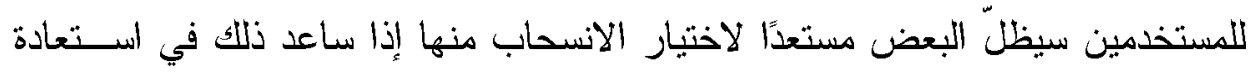
خصوصيته الرقمية استعادة دائمة إلى الأبد.

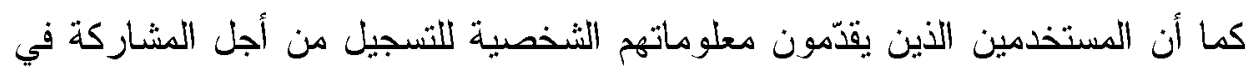

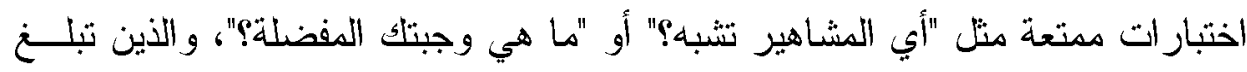
نسبتهم VI V، لن يكونوا قادرين على القيام بذلك بعد الآن. ولزبما تكــون الإشــكالية 
أكبر لدى بـ\% من المستخدمين الذين لن يتمكنو ابعد الآن مـن اسـتخدام تفاصــيل تسجيل الدخول الخاصة بصفحاتهم على شبكات التو اصل الاجتماعي في تسجيل أنفسهر بسرعة وسهولة على مختلف مواقع الويب أو خدمات الإنترنت الأخرى.

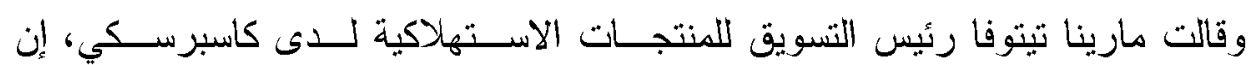

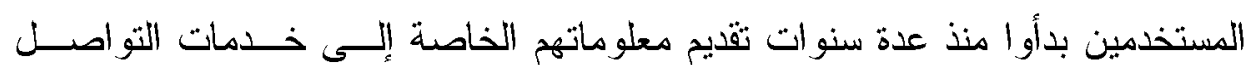
الاجتماعي في مقابل الحصول على مزايا مختلفة، من دون التفكير حتى في التهديدات

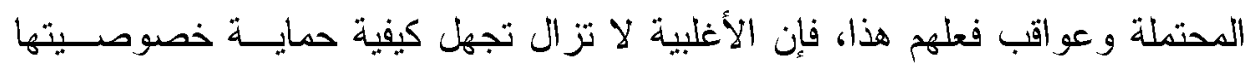
الرقمية.

هذا وقد أصبحت مواقع التو اصل الاجتماعي كالسناب شات و الفيس بوك مكانًا خصـبًا

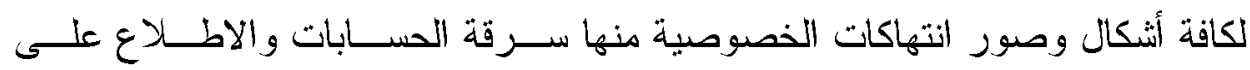

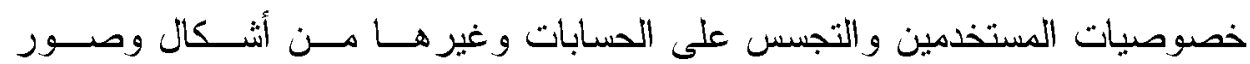
انتهاكات الخصوصية الرقمية. لذا بمكن بلورة مثكلة اللدر اسة في التساؤل التالي: كيف بتم توظيف مواقع التواصل الاجتماعي (السناب شات/الفيس بوك) في انتهاك الخصوصية الرقمية ؟

\section{(ب) أهمية الدراسة:}

تكمن أهمية الدر اسة في عدة نقاط سواء من الناحية النظرية أو التطبيقية علـى النحــو التالي:

\section{1- تتمثل أهمية اللدراسة من الناحية النظرية: -}

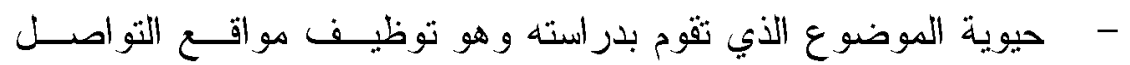

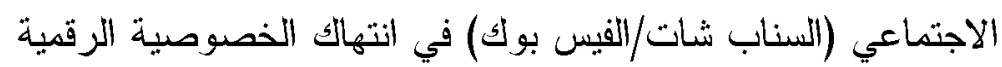

1 ) kaspersky report , "The true value of digital privacy: are consumers selling themselves short?", available on line @ https://www.kaspersky.com/blog/privacy-report-2019/ , access on 15-07-2021. 
- - يعد الموضوع إضافة معرفية من خلال تزويد المكتبات بمعلومات عـن

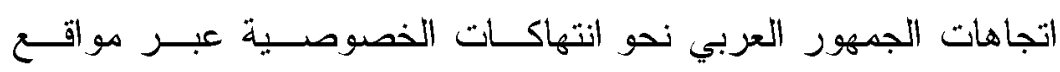

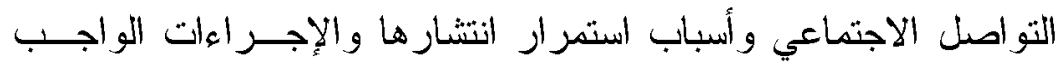
اتباعها للحد من تلك الانتهاكات.

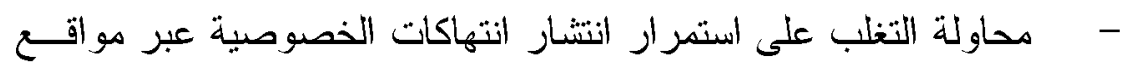
التو اصل الاجتماعي.

Y- تعتبر الاراسة الحالية من الدراسات الهامة من الناحية التطبيقية: -

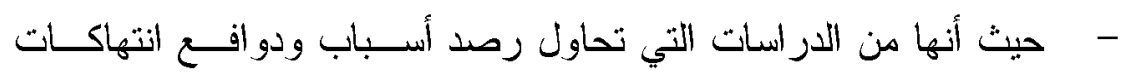
الخصوصية عبر مواقع التو اصل الاجتماعي.

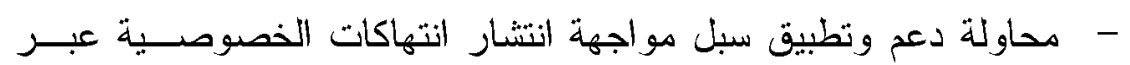
مواقع التو اصل الاجتماعي.

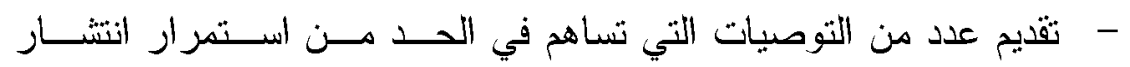

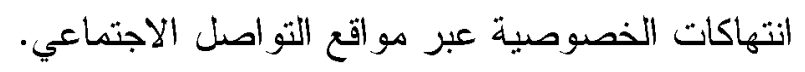

\section{ثانياً: الإجراءات المنهجية للدراسة}

\section{(أ) هدف الدراسة:}

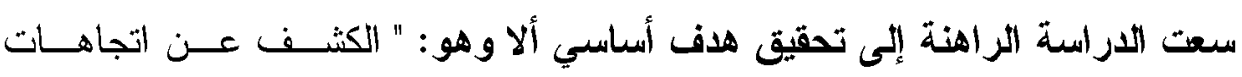

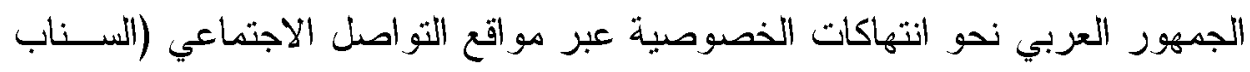
شات/الفيس بوك) ". 


\section{(ب) تساؤلات الدراسة:}

ولتحقيق هدف اللاراسة السابق تسعى الدراسة الراهنة إلى الإجابة علـى مجموعــة تساؤلات وهي كالآتي: -

ما دور مواقع التواصل الاجتماعي (الســناب شــات/الفيس بــوك) فـي

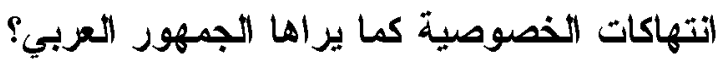

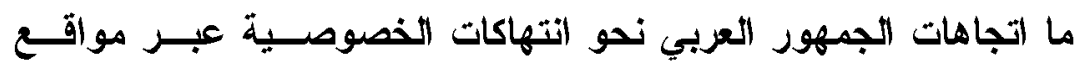
التواصل الاجتماعي (السناب شات/ الفيس بوك)؛

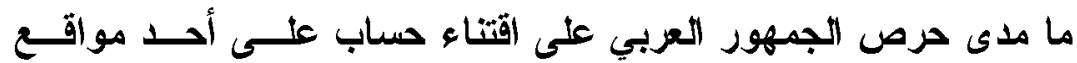
التواصل الاجتماعي؟ ما الفترة الزمنية وعدد الساعات التي يقضيها الجمهــور فــي متابعــة السناب شات/الفيس بوك؟ هل يدرك الجمهور العربي مفهوم الخصوصية الرقمية؟ ما دوافع استخدام الجمهور العربي لتطبيقي السناب شات/ الفيس بوثك؟

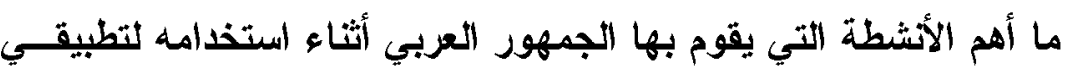
السناب شات/الفيس بوكك؟ هل يدرثك الجمهور العربي صور انتهائ الخصوصية الرقمية؟ باته

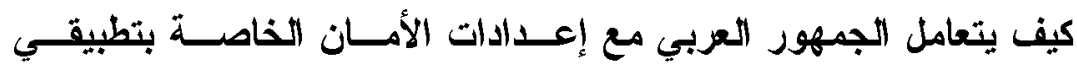

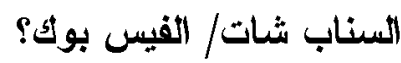
ما هي أثنكال انتهاكات الخصوصية التي يتعزض لها مستخدمي تطبيةـي السناب شات/ الفيس بوكك؟ كيف يتفاعل الجمهور العربي مع مواقف انتهاكـات الخصوصـية عبـر تطبيقي السناب شنات/الفيس بوك؟ 
ما المخاطر التي تحثثها انتهاكات الخصوصية عبر تطبيقي السناب شات/

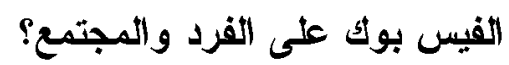

ما طرق الحد من استمرار انتثار انتهاكات الخصوصـية عبـر مواقــع التواصل الاجتماعي من وجهة نظر الجمهور؟

\section{(ج) فروض الدراسة}

توجد فروق ذات دلالة معنوية في تفضيلات الجمهور لأكثر مواقع التواصـلـ الاجتماعي متابعة لدى الجمهوروفقا لمتغير الجنسية (مصري-غير دصنية دصرب). • توجد فروق ذات دلالة معنوية في دوافع استخدام أفراد العينة لتطبيقي السناب شات / الفيس بولك وفقا لمتغير النوع (ذكور -إناث).

توجد فروق ذات دلالة معنوية في الأنشطة التي يقوم بها أفراد العينـــة أثتـــاء

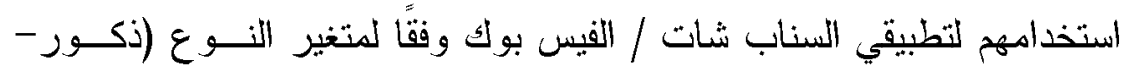
إناث).

توجد فروق ذات دلالة معنويــة فــي اتجاهــات المبحــوثين نحسو انتهـاك الخصوصية عبر تطبيقي السناب شات / الفيس بوك وفقًا لمتغيـر الجنســية

$$
\text { (مصري-غير مصرب). }
$$

\section{() التعريفات الاجرائية للدراسة}

ا - الخصوصية الثرقية Digital privacy:

تعرفها الباحثة بأنها ضمان و حماية البيانات الثخصية للمستخدمين و التي يتم نشــرها وتداولها من خلال وسائط رقمية. وتتمثل البيانات الثخصية في البريـــــالإكترونــي، 
و الصور الثخصية، ومعلومات عن العمل و المسكن وكل البيانـات التــي يســتخدمها الأفر اد في التفاعل و التعامل مع الآخرين عبر الانترنت .

r social media - مواقع التواصل الاجتماعي

تعرفها الباحثة بأنها عبارة عن مجموعة مواقع تسمح للمستخدمين بإنشــاء حسـابات

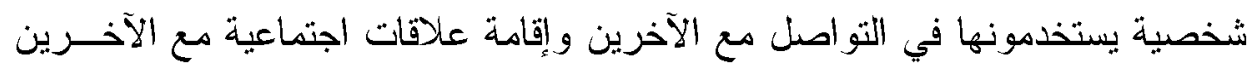

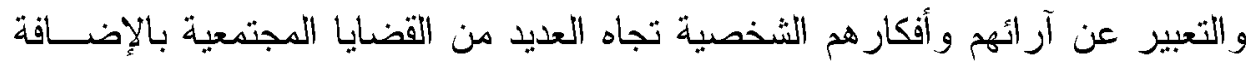

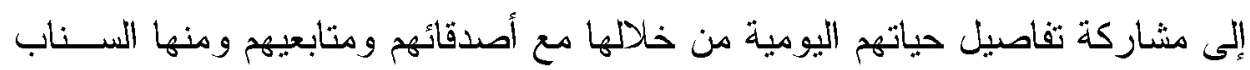

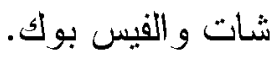

\section{r Digital privacy violations انتهاكات الخصوصية الرقمية}

تعرفها الباحثة بأنها عبارة عن نشر وإعلان مفردات الحق في الحياة الخاصة للفرد في

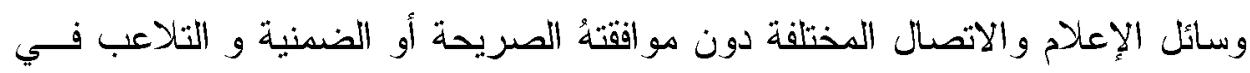

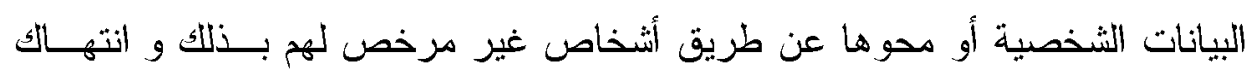

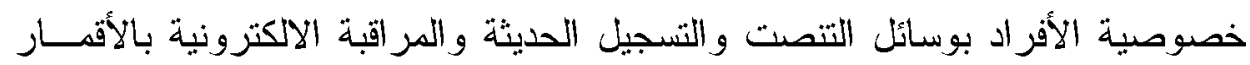
الصناعية و الكاميرات الرقية المحولة عن طريق الهو اتف المحمولة.

\section{(د) نوع ومنهم الدراسة}

1- نوع اللدراسة: تعد الدر اسة الر اهنة من الدر اسات الوصفية والتـي تهـدف إلـى

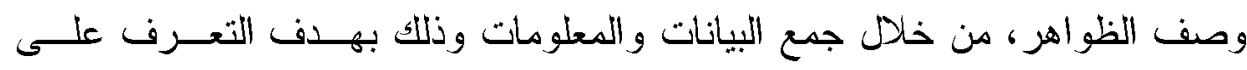

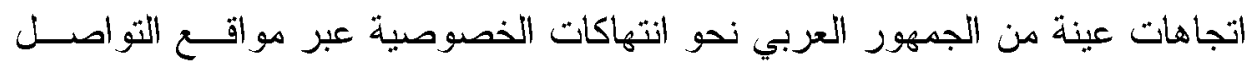
الاجتماعي (السناب شات/الفيس بوك)، مع التركيز على متغيربي جنسـية المبحـــئين والنوع وعلاقتهما باتجاهات الجمهور المختلفة. 
ب - منهجية اللار اسة: اعتمدت الدر اسة على منهج المسح الإعلامي باعتبــاره انسـبـ

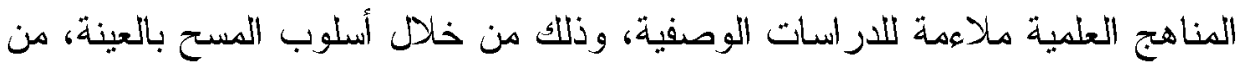
أجل وصف سمات وآراء و اتجاهات الجمهور العزبي نحو انتهاكات الخصوصية عبر مو اقع التواصل الاجتماعي (السناب شات/الفيس بوك)، بما يسمح بتعميم نتائج المســح

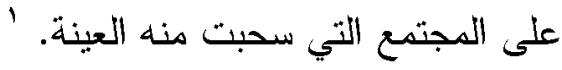
ب- أدوات جمع البيانات: اعتمدت الدراسة على صحيفة الاستقصاء الالكترونــي

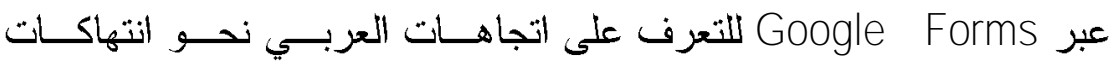
الخصوصية عبر مواقع التواصل الاجتماعي (الســناب شــات/الفيس بــوكـ)

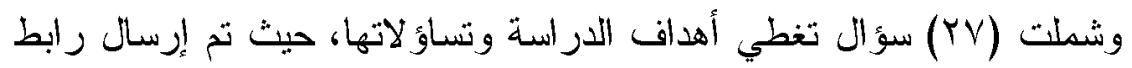

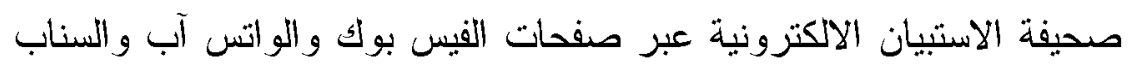
شات لعينة عمدية من الجمهور العربي (المصريين - غير المصريين). إجراءات صدق وثبات أدوات جمع البيانات:

أ) اختبار الصدق: قامت الباحثة بعرض صحيفة استطلاع رأب الجمهور الإكترونيــة على عدد من أساتذة الإعلام للتأكد من صدق أداة القباس في قياسها لمتغيرات الدار استة ومر اجعة ددى ملاعمة المقاييس لأهداف الار است، وقامت الباحثة بإجر اء التعديلات في * المقاييس بالإضافة إلى الحذف أو إعادة الصياغة بالرجوع على إلى هؤلاء المحكمين.

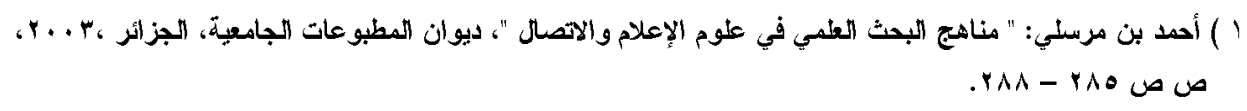
* ) تم عرض صحيفة استطلاع الرأي الجمهور على مجموعة من المحكمين التالى أسمائهي: ـ - أد: أحمد فاروق رضوان: أستاذ العلاقات العامة، بكلية الاتصال، جامعة الثارقة

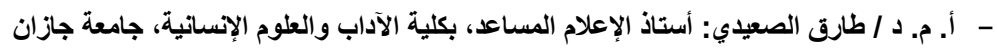

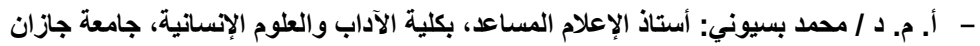

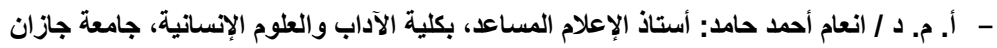


ب) اختبار الثبات: للتحقق من ثبات أداة الدراسة قاتت الباحثة بحساب معامل كرونباخ

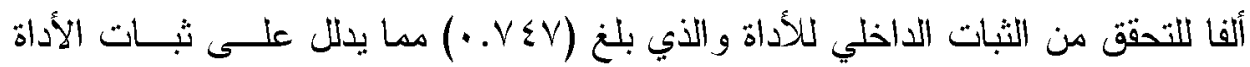
وذلك على عينة مكونة من ( (0) مفردة.

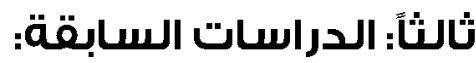

حرصت الباحثة على متابعة الباحثة للعديد من الدراسات العربية والأجنبية التي تناولت

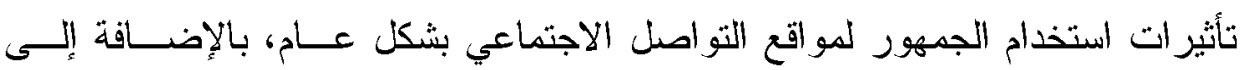

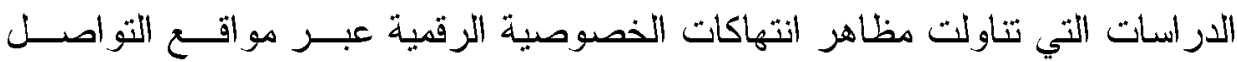

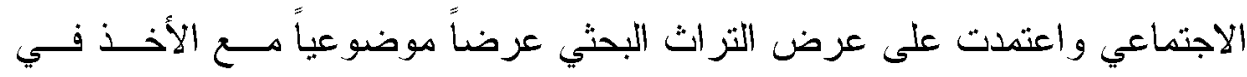

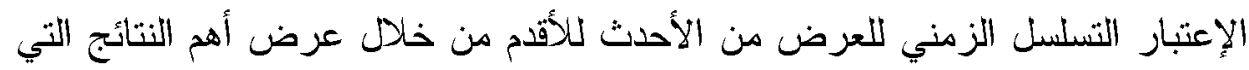
توصلت لها هذه الدراسات، كالآتي: -

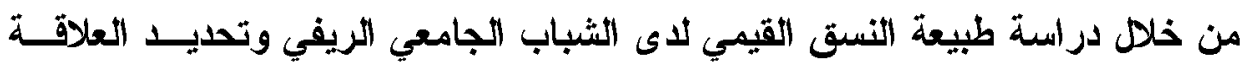

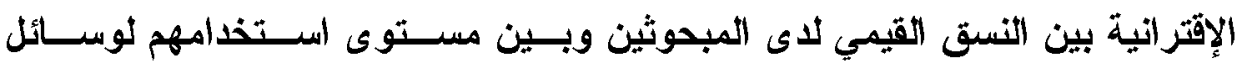

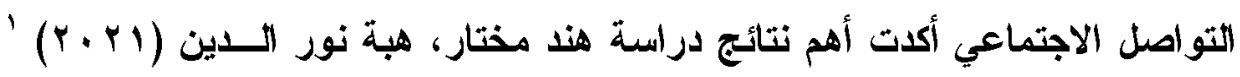

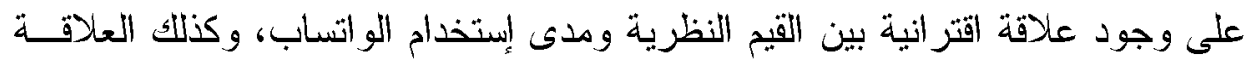
بين القيم الاقتصادية ومدى إستخدام الو اتساب و الإنستجرام والماسنجر.

ومن خلال الكثثف عن واقع الخصوصية والرهان الذي تطرحه في البيئــة الرقميــة

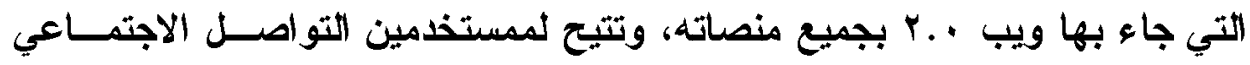

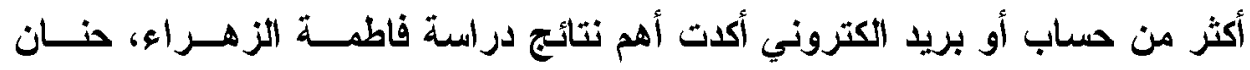

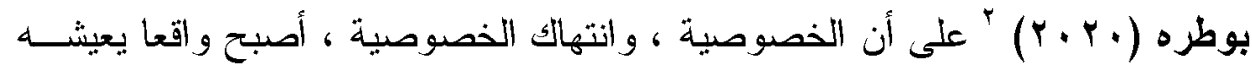

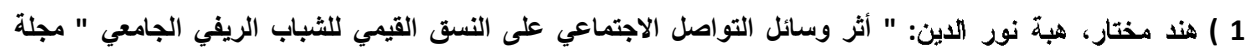

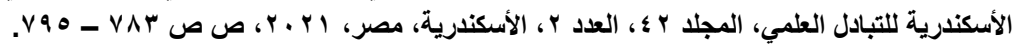

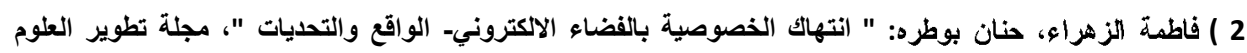

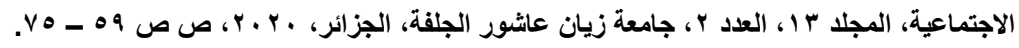


كل من ولج مو اقع التو اصل الاجتماعي باعتبار هذه الأخيرة تمثل قاعدة بيانات متتُعبة

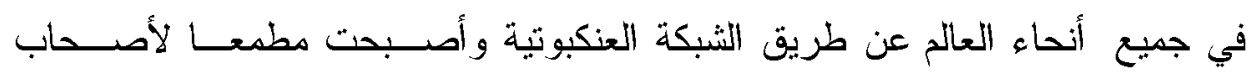

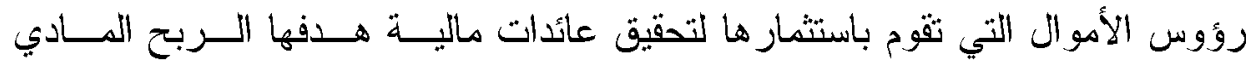

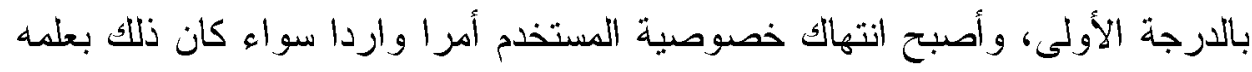

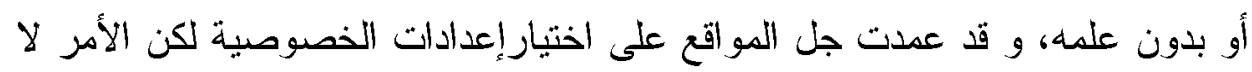
يعدو أن بكون التعرف على المستخدم بطريقة مستحدثة لذلك طرح مفهوم الخصوصية

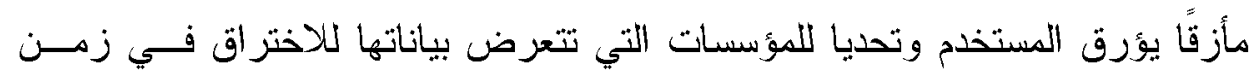

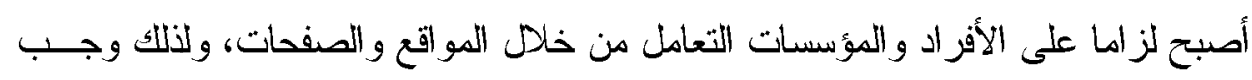
البحث عن حلول جديدة وإلا فإن العزلة والخصوصية قد أصبحتا أساسيتين للفرد.

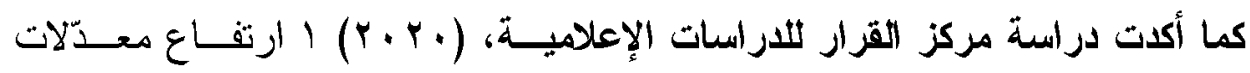
متابعة مشاهير سناب شات على المستويين اليومي والأسبوعي، ليصبح سلوكاً اتصالياً

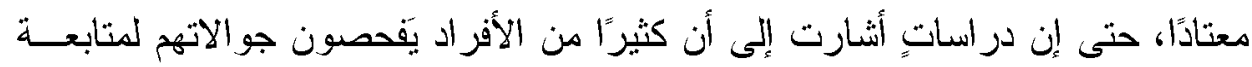

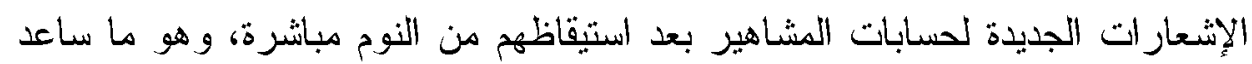

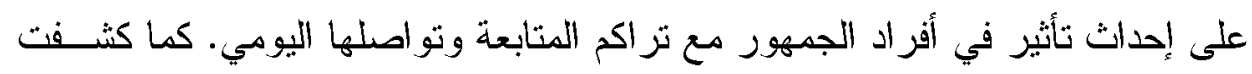

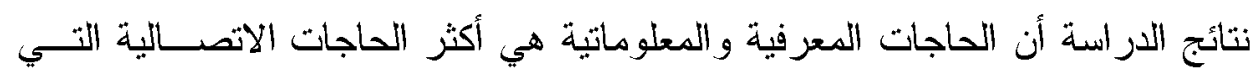

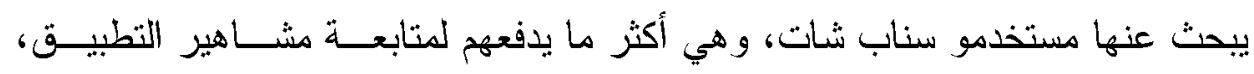

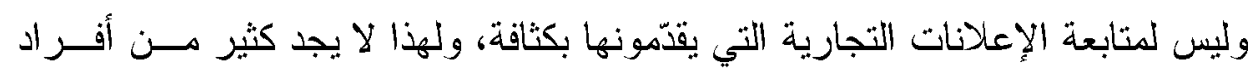

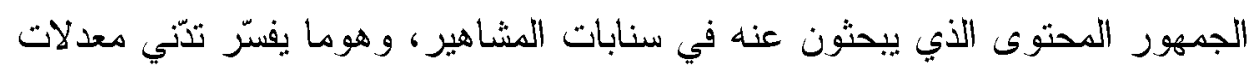

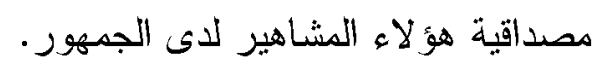

ورغم هذا التدّني في نسبة مصداقية مشاهير سناب شات لدى الجمهور ، جاء تأثير هم علـى في

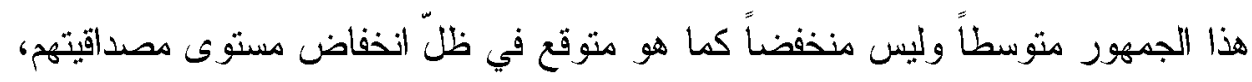

'مركز القرار للاراسات الإعلامية ( : " مشاهير ““سناب شات" في السعودية المصداقية والتأثير : دراسة تحليلية -5-2021. 29available on line @ https://alqarar.sa/1410 , access on ," 
و هو ما تفسّره الار اسة في إطار تزراكم متابعة الجمهور للمشاهير ، وتحول هذه المتابعة إلى

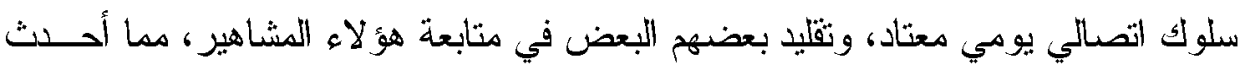
تأثيرًا ولو كان متوسطاً، وهو ما بشكل خطورة على وعي وحياة وأفر اد المجتمع.

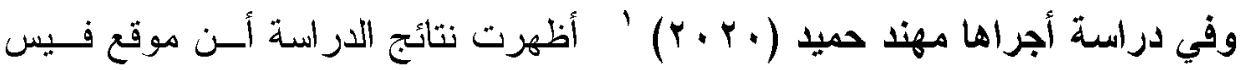

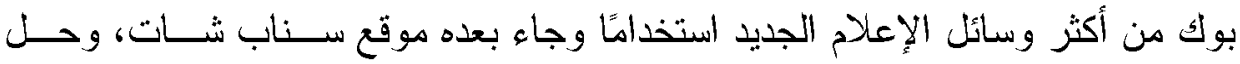
موقع يوتيوب بالمرتبة الثالثة، كما بينت النتائج أن المبحوثين يقضون أغلب وقتهم فــي مئي الدردشة و التحدث مع الآخرين، كذلك أكد أكثر من نصف المبحوثين أن وسائل الإعلام الجديد غالبًا ما تسبب مشكلات عائلية وزوجية.

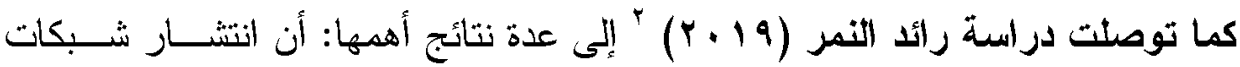

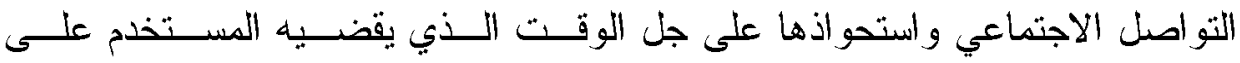
الإنترنت، أوجد حالة من التساهل في عرض الخصوصية الفردية، ومع الوقت تجاوز

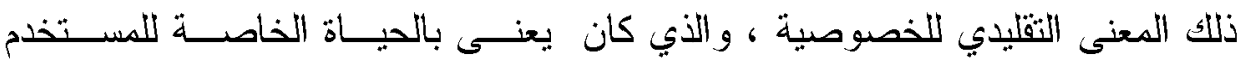
وضمان تحكمه في المعلومات التي يرغب باطلاع الغير عليها، بل والتحكم في من له ونه

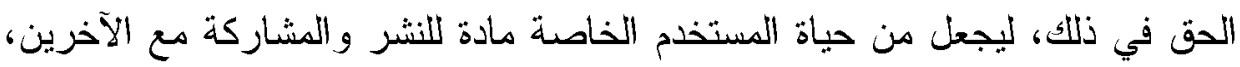

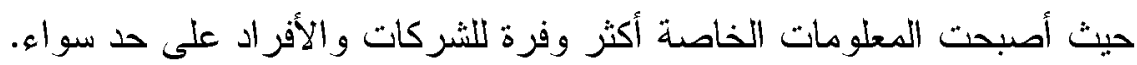
توصلت دراسة عبير محمد، سماح عيد ( (19 ) ) بإلى عدة نتائج أهمها : أن أغلب

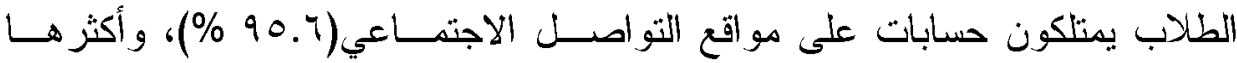

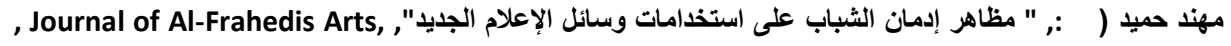
Vol (12) , Issue (42), Part I, 2020, pp (463-488), available on line @ -06-2021. 29http://www.jaa.tu.edu.iq, access on

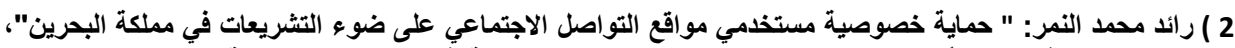

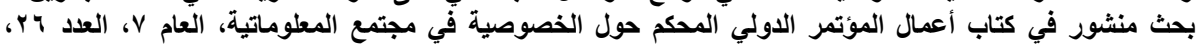

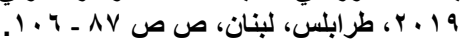

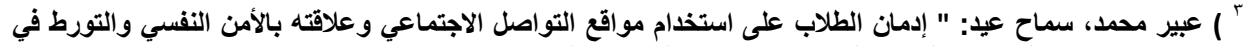

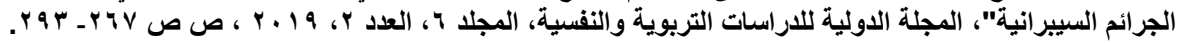


استخداما تطبيق سناب شات (بr\%)، وتستخدم غالبا بما يزيد عـن أربـع ســاعات

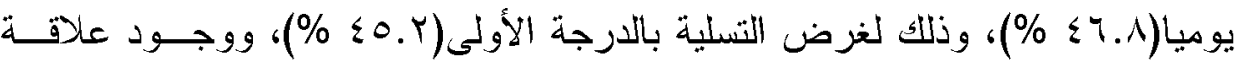

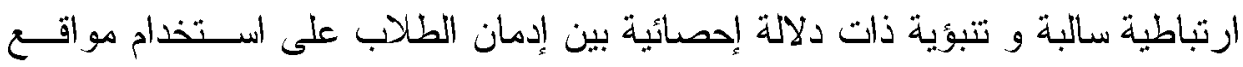

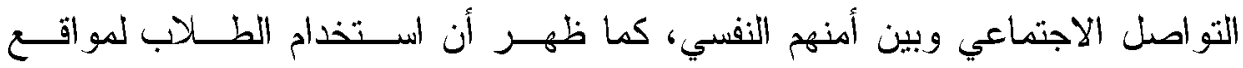

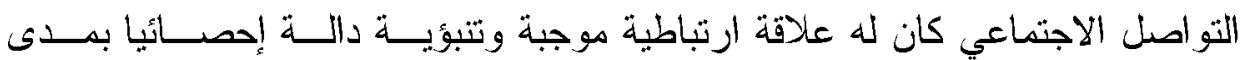

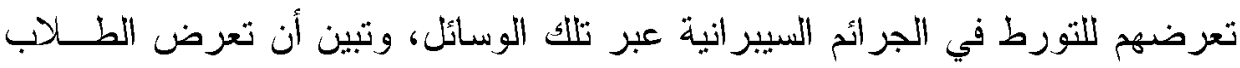
للجزائم السيبرانية عبر تلك المواقع كان له علاقة ارتباطية سالبة وتتبؤية دالة إحصائيا بأمنهز النفسي. أكلات أهم نتائج دراسة أمجد عصفوري (19 + Y) ' على أن بعض أفراد العينــة قـــ

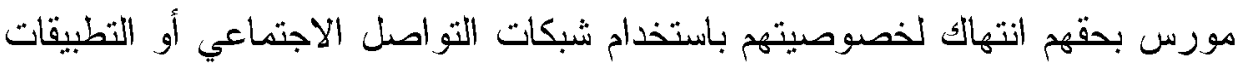

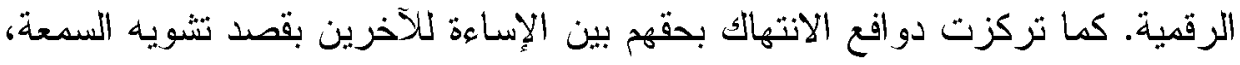

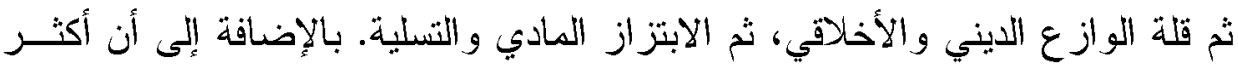

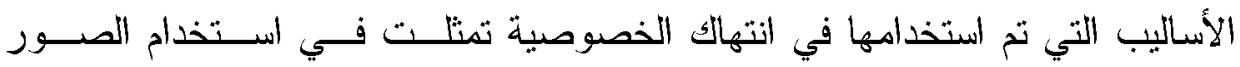
الثخصية r. . \%\%. و أكدت أيضًا على ارتفاع نسبة متابعة الشبكات الاجتماعبة بـين

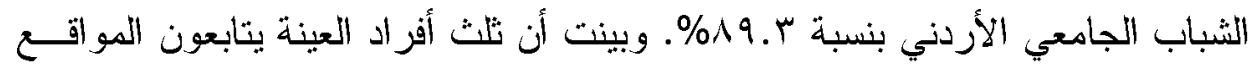
الاجتماعية من باب تقليدهم للجماعات التي ينتمون إليها.

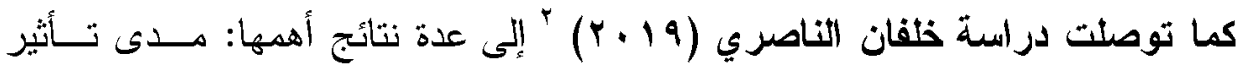
شبكات التو اصل الاجتماعي على الحقوق الرقمية من وجهة نظر عينة من طلبة ما بعد

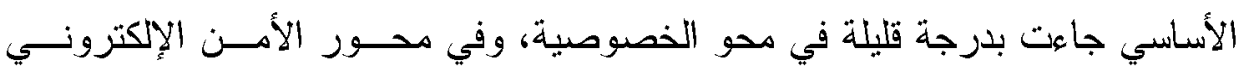

1 ) أمجد عمر عصفوري: " الثباب الأردني وانتهاك خصوصية الآخرين باستخدام شبكات التواصل الاجتماعي والتطبيقات

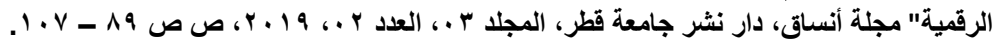

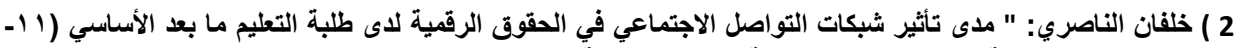

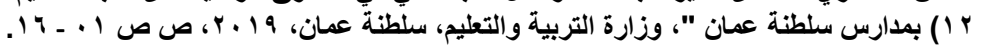


جاءت أيضا بدرجة قليلة، كما أظهرت الدراسة عن وجود فروق ذات دلالة إحصـائية بين الأكور و الإناث في مجال الدراسة وذلك لصالح الذكور .

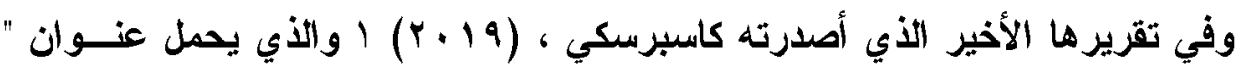
القيمة الحقيقية للخصوصية الرقمية: هل يبيع المستخدون أنفسهم على الإتترنت؟"،

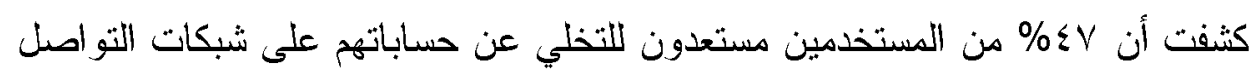

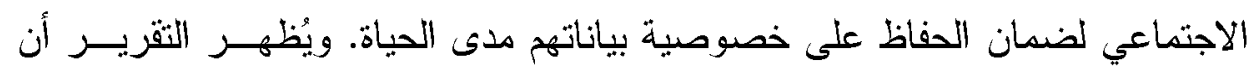

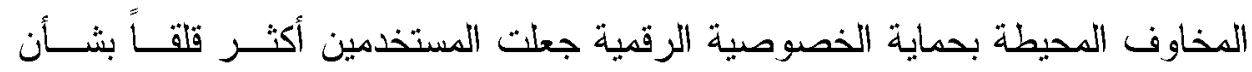

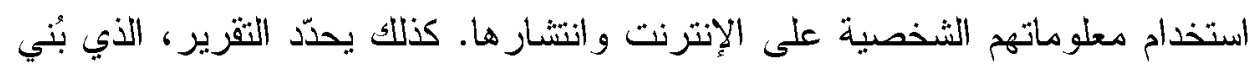

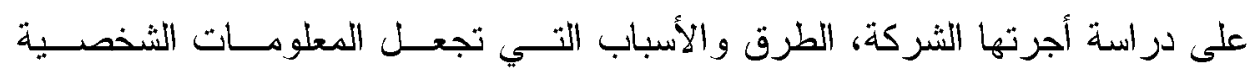
للمستخدمين بالغة القيمة لهز.

وعن اعتماد المر الهقين على الصحف الإكترونيــة وشــبكات التواصـلـل الاجتمــاعي ودورها في توعيتهم بمخاطر انتهاك الخصوصية على شبكة الإتترنت توصلت دراسة الخدي

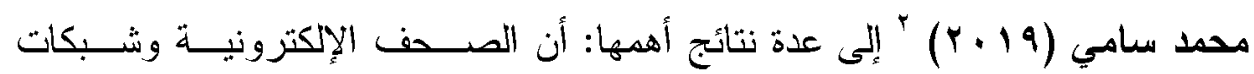

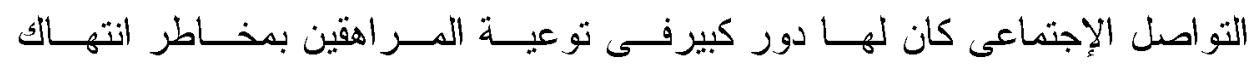

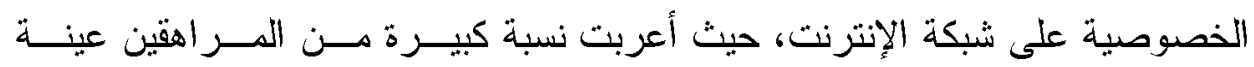
الدراسة (يتعرضون لقراعة أخبار وتقاريز صحفية من خلال الصحف الإكترونية عن الصن

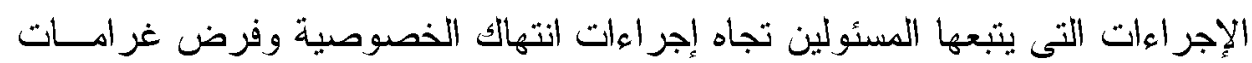

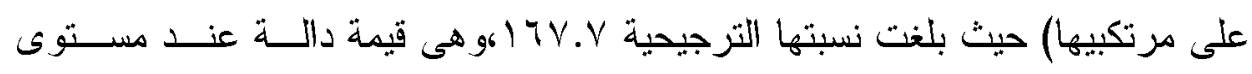

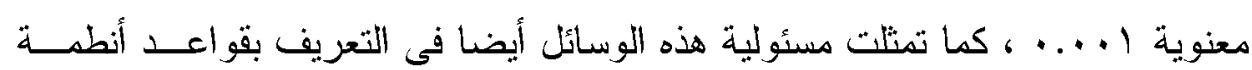

$\left.{ }^{1}\right)$ The Kaspersky Lab Global Privacy Report (2019). " The true value of digital privacy: are consumers selling themselves short?", available on line @ https://www.kaspersky.com/blog/privacy-report-2019/, access on 29-5-2021.

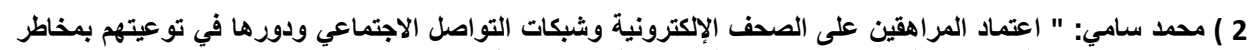

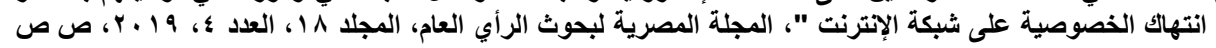




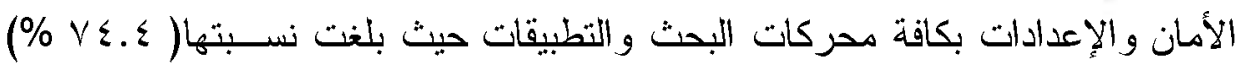
و هي دالة عند مستوى معنوية ا . ... ، وذلكك لصالح فئة المر اهقين المو افقين بشــدة،

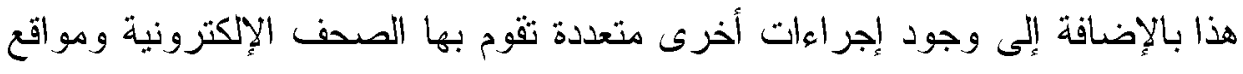
التواصل الإجتماعى من أجل توعية المراهقين بمخاطر انتهاك الخصوصية على شبكة الإنية الإنترنت.

توصلت دراسة ربيعة ميمون في دراستها (19 ب r) ' عن انتهايك الخصوصية عثى موقع التواصل الاجتماعي الفيس بوثك دراسة ميدانية لعينة من تلاميذ ثانويات بمدينة

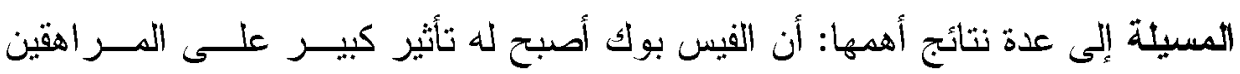
خاصة من خلال ما ينشرونه من يومياتهم أدى هذا الى تأكل الخصوصية و انعدامها.

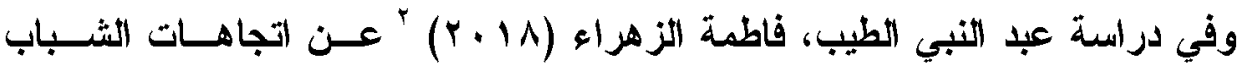
اللسوداني نحو انتهاك الخصوصية علي مواقع التواصل الاجتماعي توصلا إلى عـدة

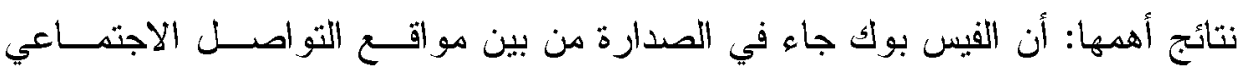

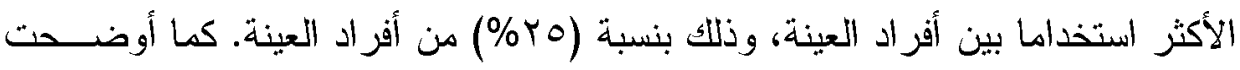

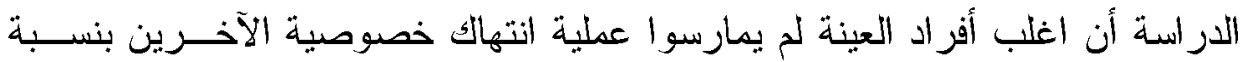

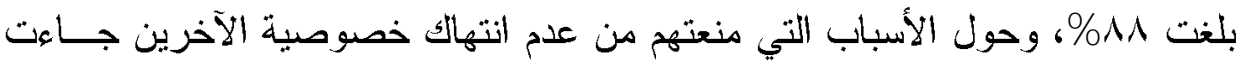
الأسباب الدينية والأخلاقية في المقدمة وبنسبة بلغت ب0\% ثم جاء الخوف من العقـاب

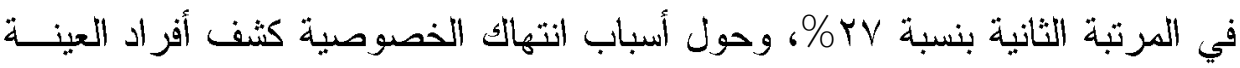

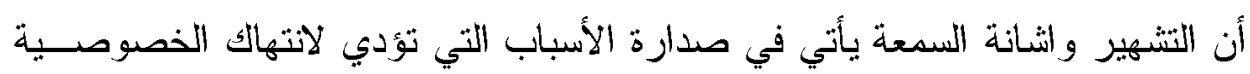

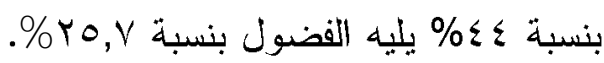

1 بييعة ميمون ( :," انتهاك الخصوصية على موقع التواصل الاجتماعي الفيس بوك دراسة ميدانية لعينة من تلاميذ ثانويات

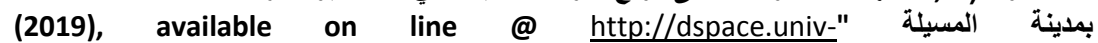
-06-2021. 29msila.dz:8080//xmlui/handle/123456789/17130, access on

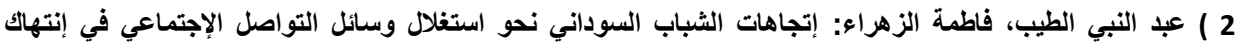

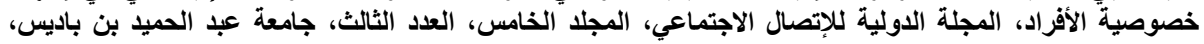

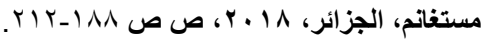




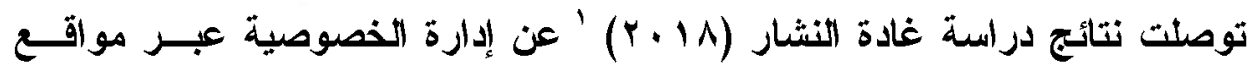

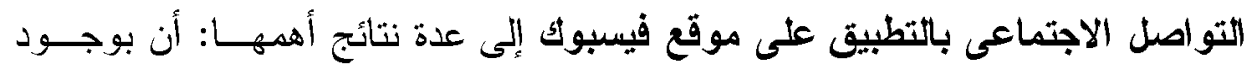

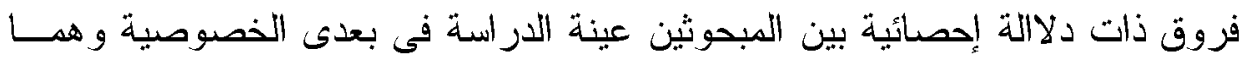

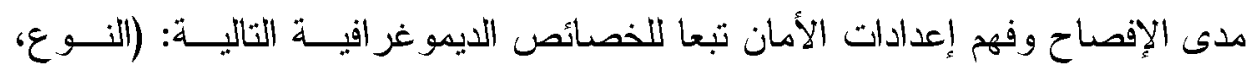

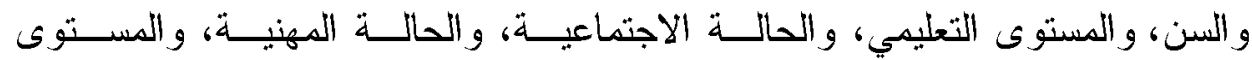
الاقتصادي والاجتماعي)، قد انتهى إلى ثبوت صحة الفرض الفزض بشكل جزئي فمبا يخص متغيري النوع و السن. وقد سعت هذه الدراسة لاستجلاء مفهــوم الخصوصــية وذللك من و اقع ممارسة المستخدمين، وقد تعاملت مع الخصوصية إجر ائََّّا باعتبـــاره

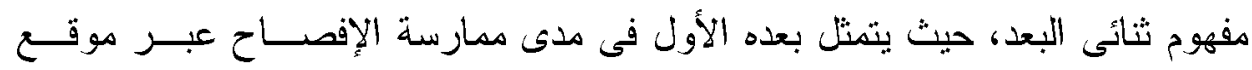

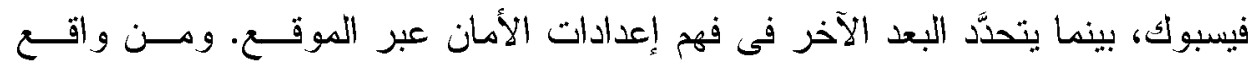

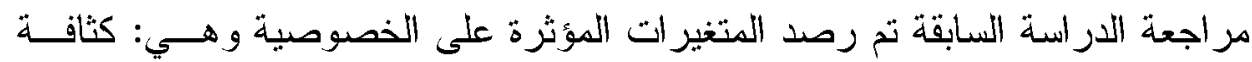

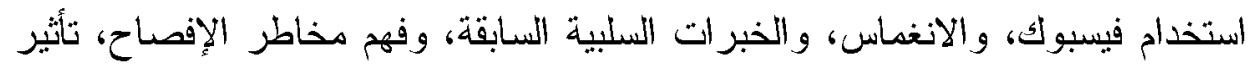

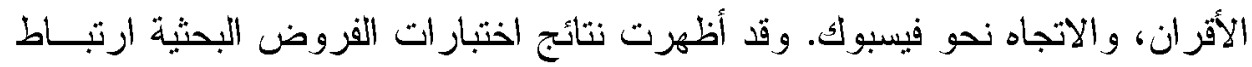

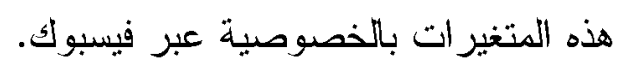

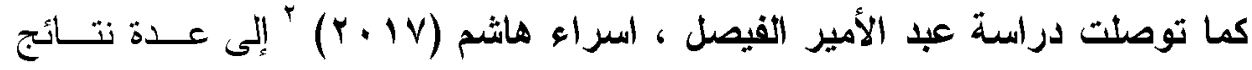

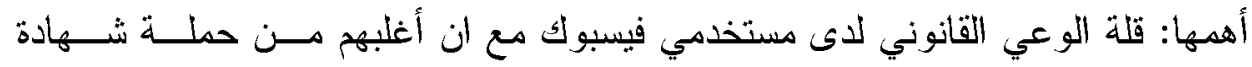
البكلوريوس بسبب عدم اسهام بلدانهم بنشر الو عي القانوني وتتقيف المجتمع وتعـريفهر بحق الخصوصية واختلافه من بلد لاخر، بالإضافة إلى التتاقض في أجوبة المبحـــثين لاسيما فيما يتعلق بقراعته لسياسة الخصوصية اذا تلل اغلب اجاباتهر عـن الاسـئلة

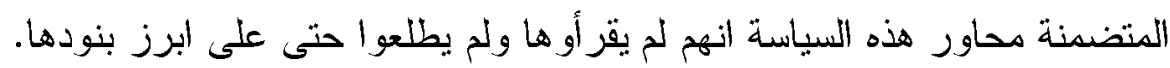

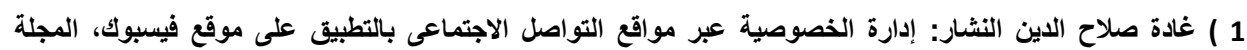

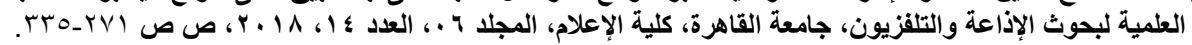

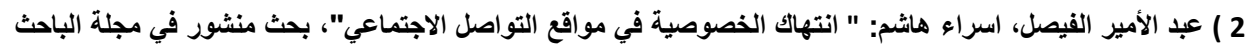

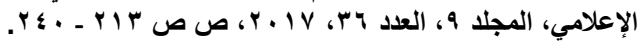


أوضحت نتائج دراسة ( كاثرين ساريكاكيس وآخرون ) عن استكثاف الطرق التـى يفهم بها مفهوم الخصوصية فى سياق وسائل التواصل الاجتمــاعى، وفيمـــ يتعـــق

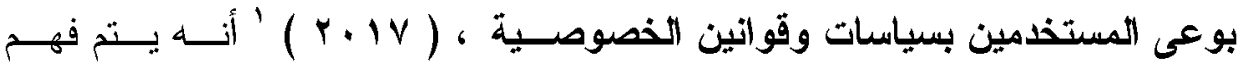
الخصوصية على مستوى العالم على أنها مسألة تحكم الأفر اد، وترتبط بقــوة بقضــــايا الاستقلال الذاتى، كما تبين أنه على الزغم من التغطية الواسعة النطاق للقضايا القانونية المتعلقة بالخصوصية فى الصحافة، فإن مخاوف المستخدمين و المشاركة فيهــا تســتمد

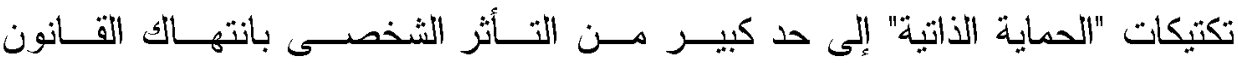
و الخصوصية.

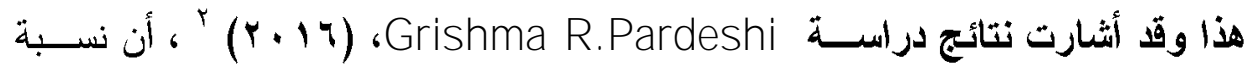

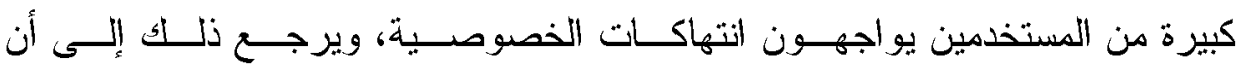
المستخدمين يقومون بمشاركة المحتوى عن طريق منشورات وصور عن نفسه وكذلك الآخرين، كما تبين أنه يمكن للجمهور إعادة مشاركة المحتوى مما يجعله فى متتــاول

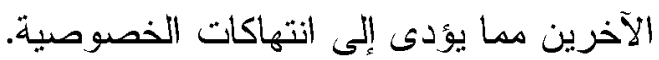

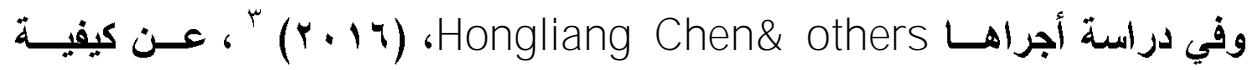
حماية البيانات على الإتترنت أوضحت نتائج الاراسة أن المستخدمي الاصــغر ســـان

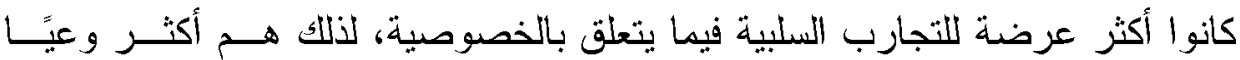
بالأفصاح عن المعلومات عبر الانترنت وأكثر اعتمادًا على أساليب حماية الخصوصية بانية

\footnotetext{
${ }^{1}$ ) Katharine Sarikakis \& Lisa Winter. "Social Media Users' Legal Consciousness about Privacy". Social Media \& Society, 2017, pp.1-14.

2 ) Grishma R.Pardeshi. " A Critical Review of Detection of Privacy Violation in Online Social Network". International Research Journal

of Engineeringand Technology (IRJET) , 2016, Vol.03, Issue.12, pp. 1189 - 1195.

${ }^{3}$ ) Hongliang Chen, Christopher E. Beaudoin, and Traci Hong ، Protecting Oneself Online : The Effects of Negative Privacy Experiences, on Privacy Protective Behaviors, Journalism \& Mass Communication Quarterly, 2016, Vol. 93(2), pp. 409-429.
} 
على الانترنت، وكذلك اتضح أن الأشخاص ذوب المستويات التعليمية العليا أكثر وعيًا

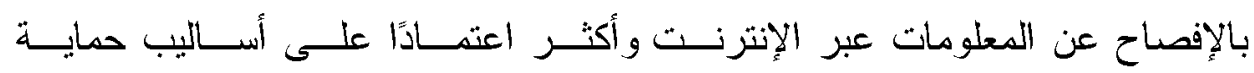
الخصوصية.

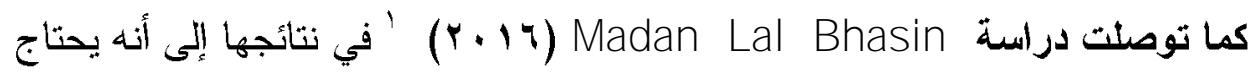

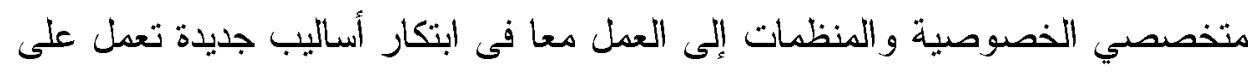

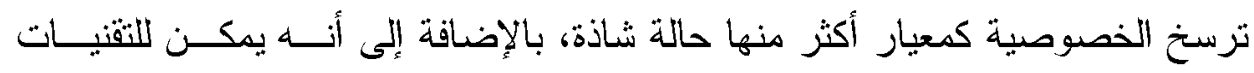
الناشئة حماية الخصوصية دون تقييد تدفق المعلومات بالنسبة للمنظمات الفعالة.

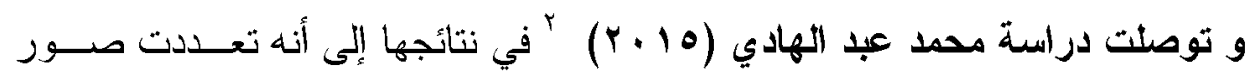

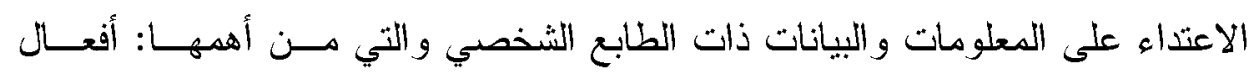

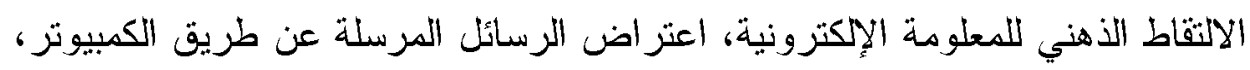
الإفشاء غير المشروع للبيانات، التهديد بالاستغلال غير المشروع للأسرار الشخصية.

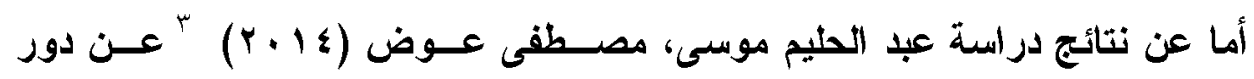
مواقع التواصل الاجتماعي في انتهاك خصوصية وحريات المستخدمين فقد أكـدت أن أن

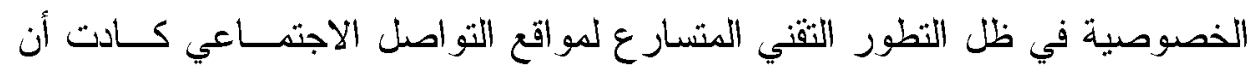

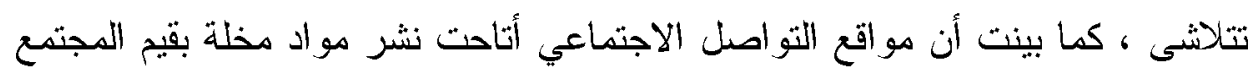

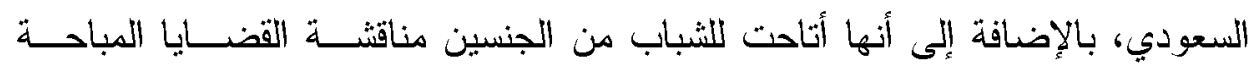

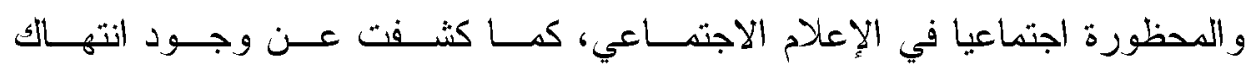

\footnotetext{
${ }^{1}$ ) Madan Lal Bhasin., " Challenge of guarding online privacy: role of privacy seals, government regulations and technological solutions", Social'no-ekonomičnì Problemì ì Deržava, 15 ( 02 ) , 2016 , pp 85-104 .

r أبد الحليم موسى، مصطفى عوض: " دور مواقع التواصل الاجتماعي في انتهاك خصوصية وحريات المستخدمين:

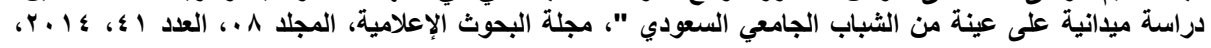

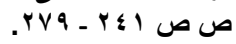
"محمد عيد عبد الهادي القحطاني ( :," حماية الخصوصية الثخصية لمستخدمي مواقع التواصل الاجتماعي ", (2015) , available on line@ @ttps://repository.nauss.edu.sa/handle/123456789/62524 , access on
} 
للخصوصية بين الجنسين عبر مواقع التواصل الاجتماعي تحت ذريعة حريــة الــرأي

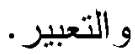

\section{رابعاً : الإطار النظري للدراسة '}

تحتل النظرية العلمية مكانة متميزة في البحث العلمي بصفة عامة سواء أكان موضوع

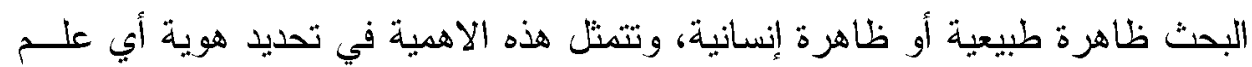

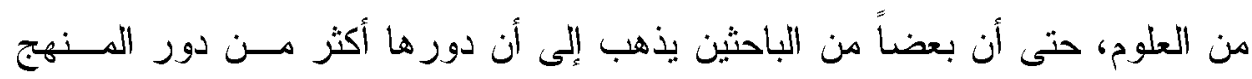

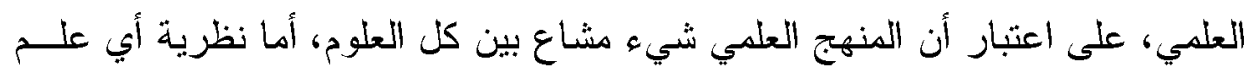

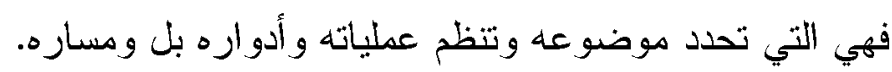
لذا فقد اعتمدت الباحثة على تبني الاتجاه التكاملي الذي لا بعتمد على اتجــاه نظـــــي

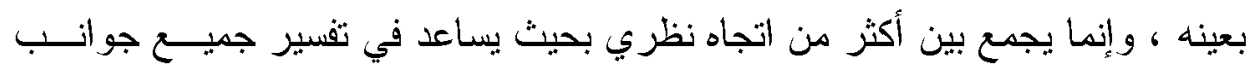

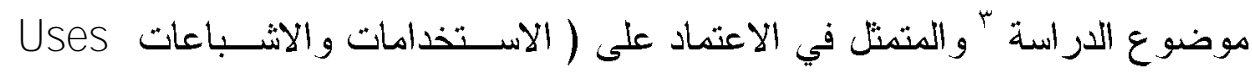
كاتجاه رئيسي في تفسير موضوع الاراسة ، وتنبي (and Gratifications Theory

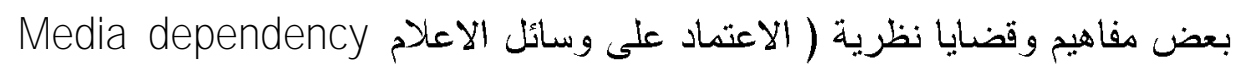
(theory

1- نظرية الاستخدامات والاثباعات Uses and Gratifications Theory

تعتبر نظرية الاستخدامات والاشباعات من النظريات التي جـاءت لتكمـل دراسـات

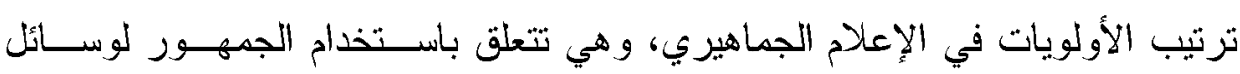

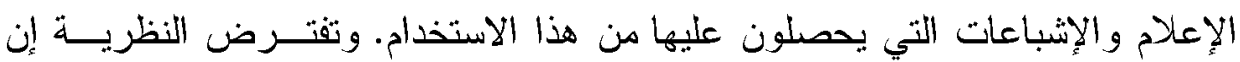

\footnotetext{
) سالي سعد جودة إبراهيم: دور المعلوماتية في التسويق السياحي لمصر الفيس بوك نمونجاً، بحث منشور في مجلة

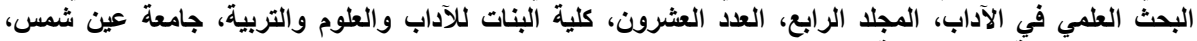

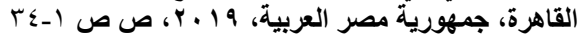

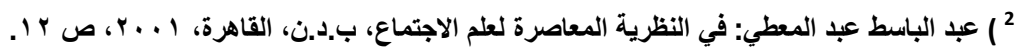

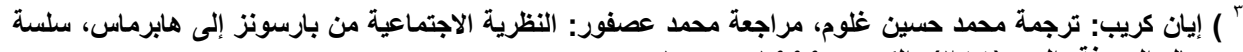

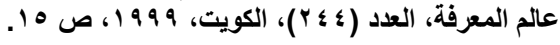
r.
} 
الافتر اض الأساسي للاستخدامات والإشباعات هو أن جمهور الإعلام الجمــاهيري لا يشتمل على أشخاص سلبيين تم استخدامهر من خلال الحافز الإعلامي (حافز الوسيلة)،

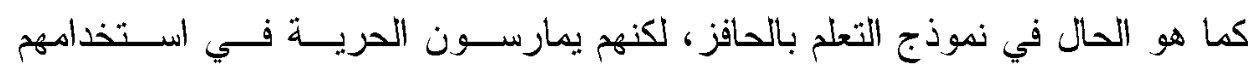
لنلإعلام.

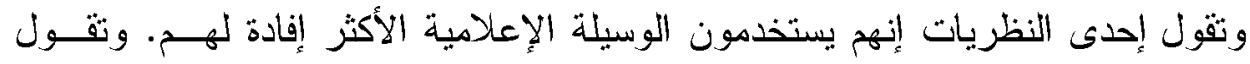

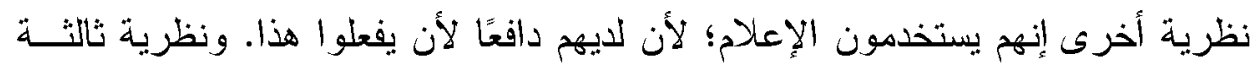

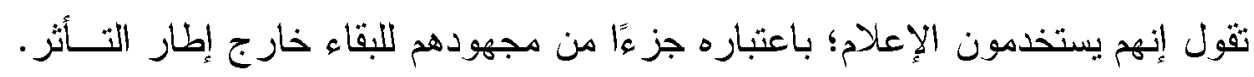

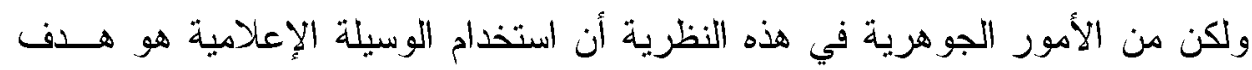

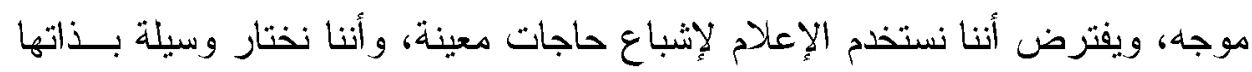

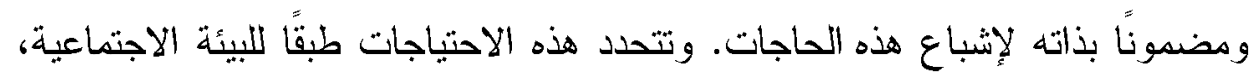
و التي تتضمن عناصر ها: السن والنوع و الحالة الاجتماعية والانتماء للجماعة و السمات

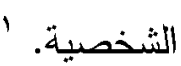

و استندت النظرية على مجموعة من الفروض وفقًا لكاتز وبلومر، وهي: ‘

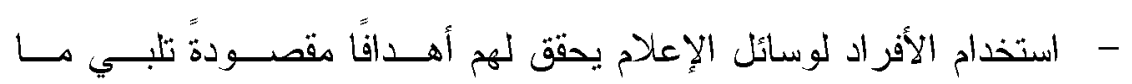

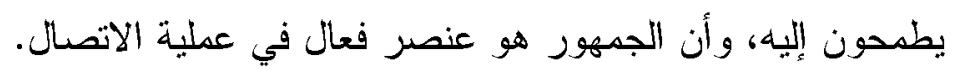

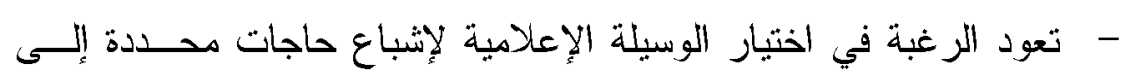

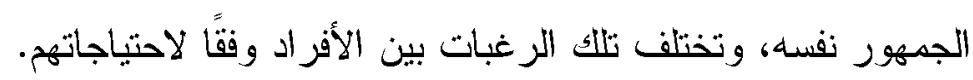

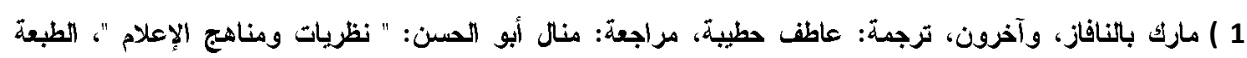

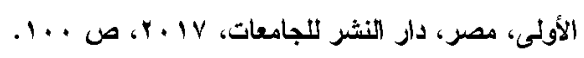

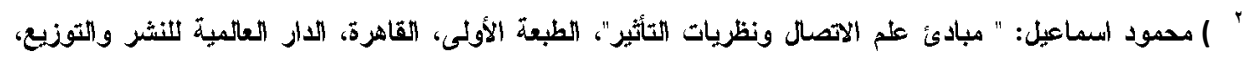
.ros ص.r.r. 
- الأفر اد هم من يختارون وسائل الإعلام التي تشبع رغبــاتهم، فالوسـيلة الإعلامية لا تستخدم الجمهور بل الجمهور هو من يستخدمها.

- يعلم الجمهور مدى الفائدة التي قد يجنيها نتيجة اختباره لوسائل الإعــلام التي يتعرض لها، وهو أعلم أيضًا بدو افعه و احتباجاته.

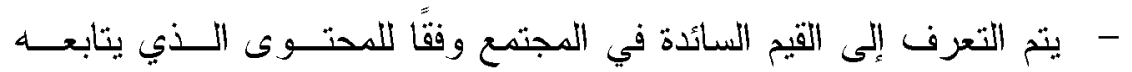
الجمهور ، وليس المحتوى الأي تقدمه وسائل الإعلام.

كما تفتز ضنرية الاستخدامات و الإشباعات مجمو عة الفروض الآتية: 1 - جمهور المتلقين هو جمهور نشط، واستخدامه لوســائل الإعــلام هـو استخدام موجه لتحقيق أهداف معينة . هورئ

Y - يمتلك أعضاء الجمهور المبادرة في تحقيق العلاقة بين إثباع الحاجات واختبار وسائل معينة يرى أنها تشبع حاجاته. r - تتافس وسائل الإعلام مصادر أخرى لإشباع الحاجات. ؛ - الجمهور وحده هو القادر على تحديد الصورة الحقيقية لاستخدام وسائل الإعلام. ه - الجمهور نفسه هو الذي يحدد الأحكام حول قيمة العلاقة بين الحاجـات

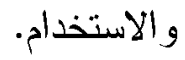
7 - الأفر اد يستخدمون وسائل الإعلام لحل مشاكلهم فيما يتعلق بالبحث عن المعلومات و الاتصال الاجتماعي و التعلم الاجتماعي . لاعل وسل

' ) مصطفى علي سيد : " الاتجاهات (الحيثة لنظرية الاستخدامات والاثباعات"، المجلة المصرية للاراسات المتخصصة،

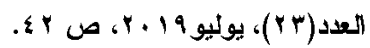
rr 
V - يختار الأفر اد من مضمون وسائل الإعلام ما يتناسب مـــع احتياجـاتهم

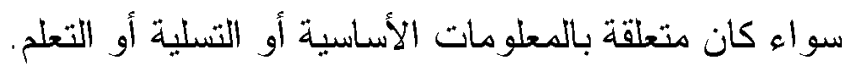

\section{نظرية الاستخدامات والإثباعات والاتترنت}

تعد نظرية الاستخدامات والإشباعات هي المدخل الأكثر ملاءهــة لدراســـة اســتخدام

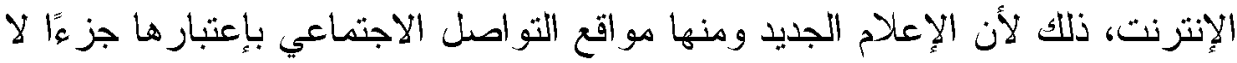

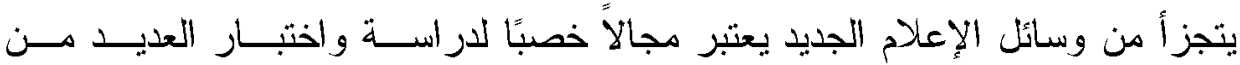
النظريات و النماذج ومنها نظرية الاستخدامات و الاشباعات.

ويعتبر الإنترنت وسيلة اتصال جديدة ومبتكرة من المككن أن تساهم في تغييـر حيـاة

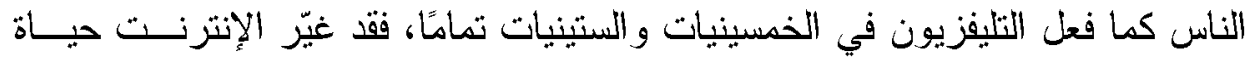
الناس من خلال الوصول إلى الكثير من المعلومات و المساهمة في نشــرها وقييمهــا و إنثاؤها بسرعة ويسر، كما ساعد على التو اصل مي العديد من الأشخاص المختلفـين

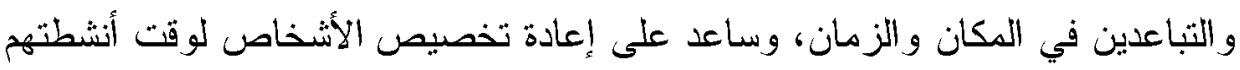

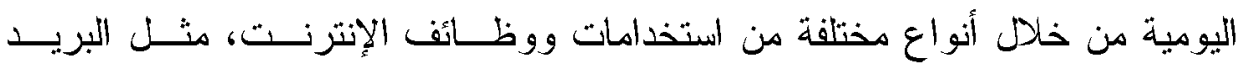
الإلكتروني ومجمو عات الأخبار و غير ها.

يعتبر جمهور الإنترنت بشكل عام وجمهور مواقع التواصل الاجتماعي بشكل خـاص

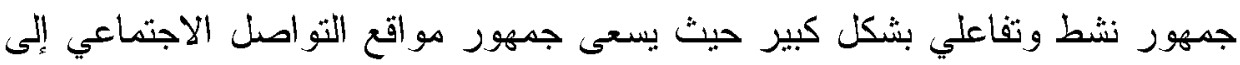

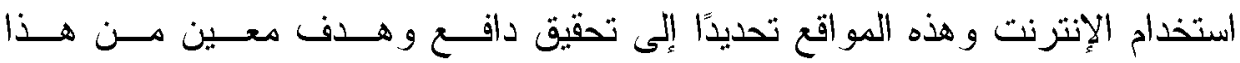

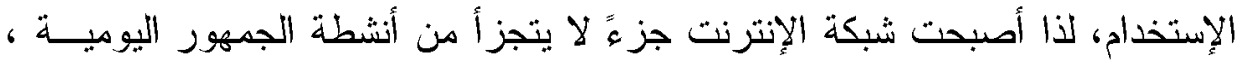

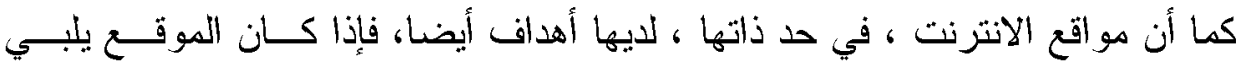
متطلبات المتسوقين عبر الإنترنت، فإن الهذف من موقع الويب هو بيع البضــائع، و إذا

) Hiremath Veerabasayya Rudrayya : Uses and Gratification of Internet among College Students: A Study in Karnataka State, Doctor of Philosophy in Communication and Journalism , University of Mysore, Karnataka, India ,March 2013., P 28. 
كان موقع الويب هو محرك بحث ، فإن الهذف هو توفير النتائج ذات الصلة، وإذا كان

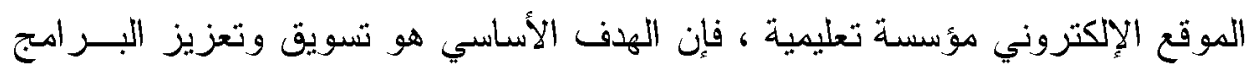

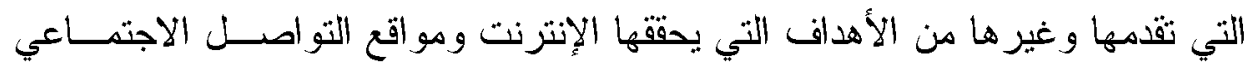
لالجمهور.

أهم الإثباعات المتحققة لاى الجمهور المستخدم للإِترنت ' تتمثل الإشباعات المتحققة لجمهور مستخدمي الإنترنت في الآتي: ا- استكشاف كل ما هو جديد في العالم الخارجي Browsing and Exploring

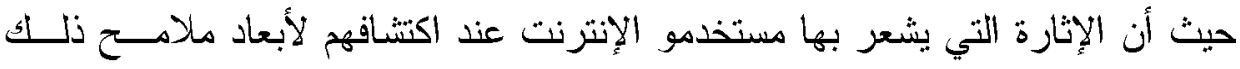

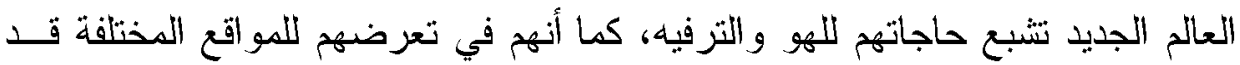
يصادفون ما يشبع احتياجات معرفية لديهم. r- البحث عن المعلومات حيث أن بV \% من مستخدمي الإنترنت يبحثون عن المعلومات في مختلــ مجــاتلات الحياة، وتستطيع شبكة الويب إثباع الاحتباجات المعرفية لدى المستخدمين.

بntertainment باستمتاع و التسلية حيث أن ه \% من مستخدمي شبكة الويب يقومون بذلك للتسلية والترفيه. ع- الاتصال بالآخرين Communication with other virtual presence تحقيق الوجود الافتر اضي ويعني شعور المستخدم بالتو اجد في بيئة افتز اضية يتيحها الكمبيوتر وتختلف عن البيئة المادية الفعلية الموجود بها. 
كما يمكن تقسيم الإشباعات الذبي تقدمها شبكة الانترنت لمستخدميها على النحو الآتي: 1 -إثباع المحتوى: وينتج هذا النوع من الإشباعات عن استخدام شبكة الانترنت من أجل المحتوى لا من أجل الوسيلة نفسها، وينقسم إلى قسمين:

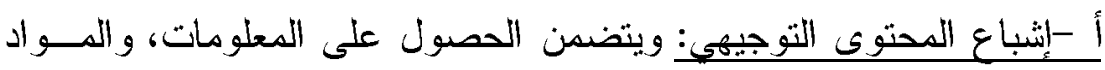

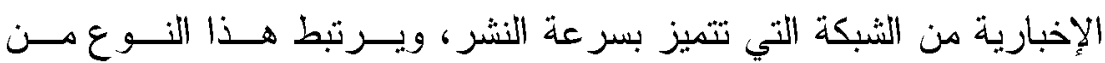

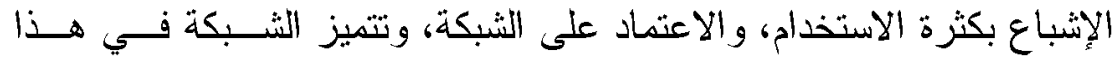

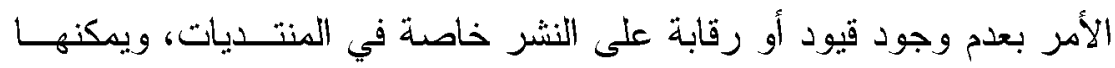
ذلك من نشر معلومات، وأخبار من كل الأنواع، لا يمكن أن تتشر في وسائل ولئل الإعلام التقليدية. ب -إثباع المحتوى الاجتماعي: ويقصد به الربط بــين المعلومــات التـي يحل عليها الفرد من الشبكة، و علاقاته الاجتماعية.

2 -إثباع الاتصال: وهي الإشباعات الناتجة عن استخدام شبكة الانترنت نفسها،

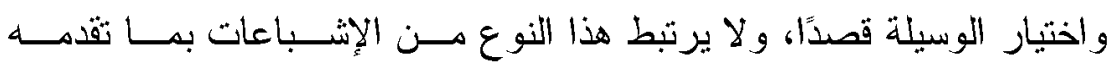
الانترنت من محتوى، وينقسم إلى قسمين:

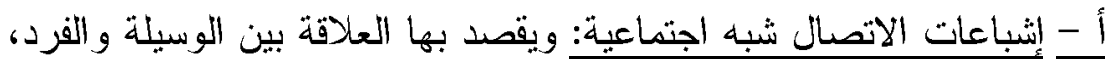

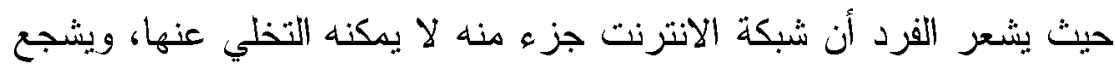

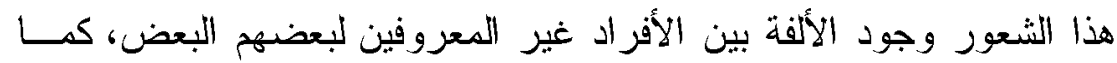

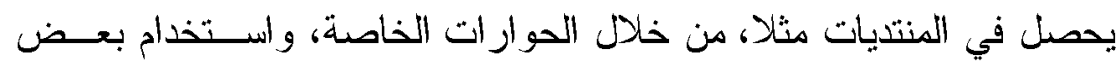
الألفاظ الخاصة التي تدل على ألفة بينهم. ب - إشباعات الاتصـال شبه توجيهية: ويتحقق هذا النوع من الإشــباع مـن

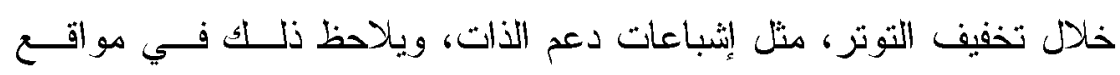




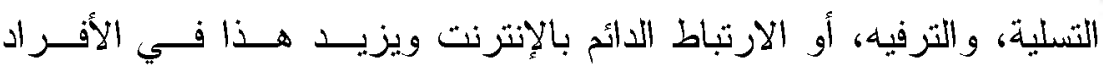

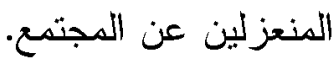

وتطبيقياً فقد ساعد استخدام الإنترنت لمسح استخدامات وإثباعات الجمهور من خـلال

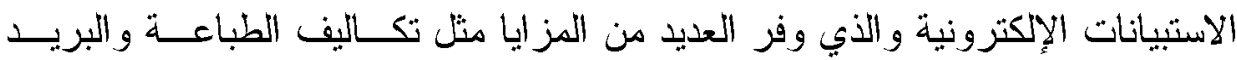

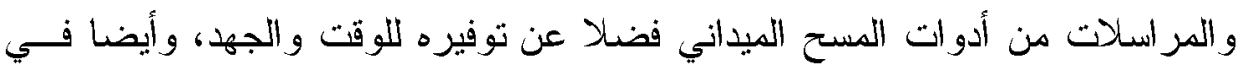
الحصول على الييانات في شكل إلكتروني.

وبالتطبيق على الدراسة الراهنــة ووفقاً لنظرية الاستخدامات و الاشباعات فإن الدراسة

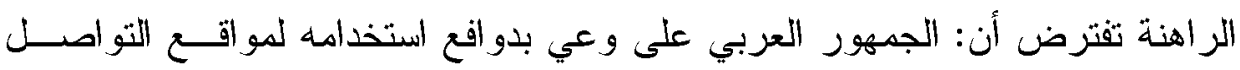

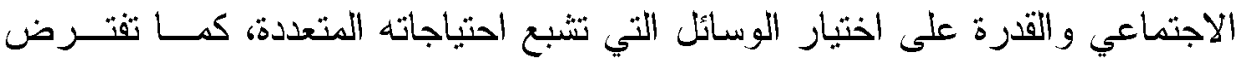

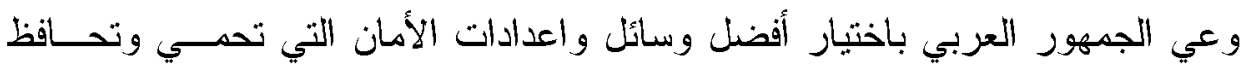

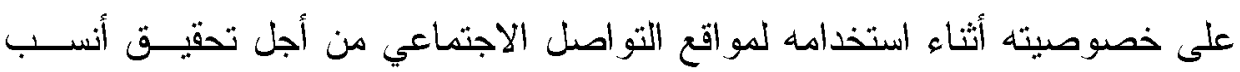
اشباع لدو افعها أثناء الاستخدام.

بالإضافة إلى أنه وبالتطبيق على فروض نظرية الاستخدامات و الاشباعات فإن الدراسة

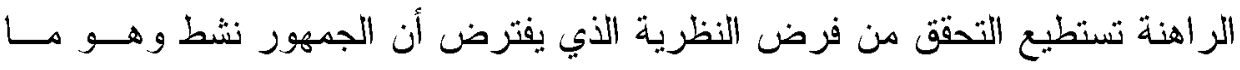

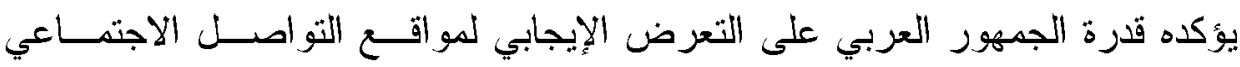

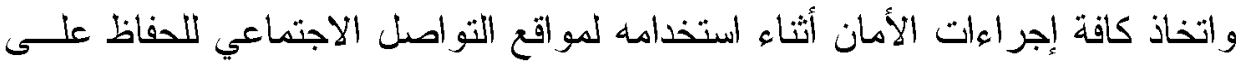
أكبر قدر من الخصوصية الرقمية أثناء تعامله مع هذه المواقع.

\section{r - الاعتماد على وسائل الاعلام Media dependency theory:}

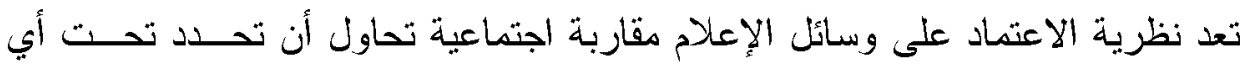

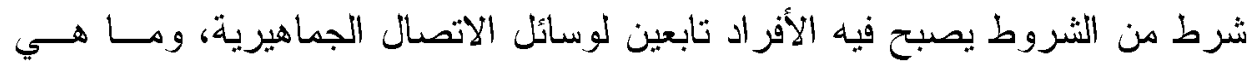

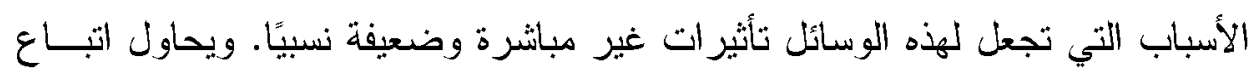

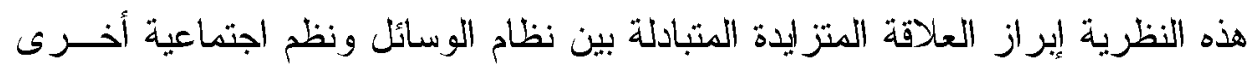


و الجمهور في إطار تركيب عضوب. إن هذا التفاعل يؤثر على محتوى وسائل الإعلام

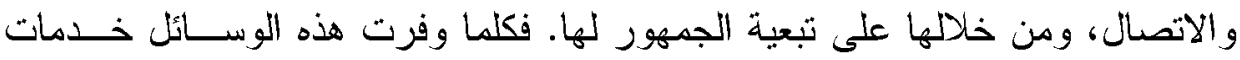

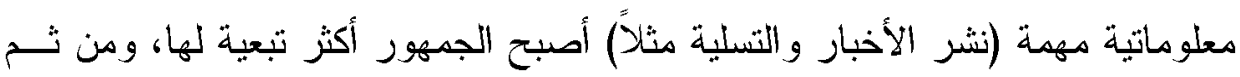

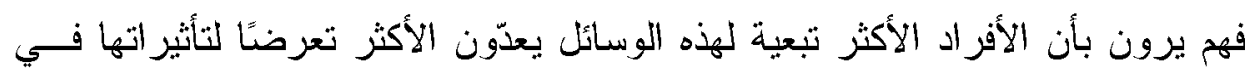
معتقداتهم وتصور اتهم عمومًا.

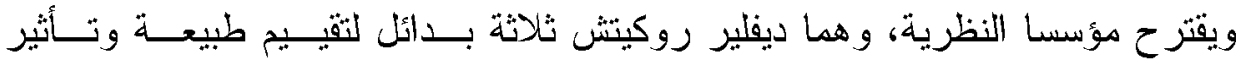
الاتصال الجماهيربي و هي كالآتي: الأول: من النوع البنيوب ويوجّه إلى تشخيص الظروف السياسية والاقتصادية و الثقافية التي شكلت كيفية عمل وسائل الاتصال الجماهيرية في وقت تاريخي محدد. الثاني: بديل مقارن ويهذف إلى تتخيص أوجه التشابه والاخـتلاف بـين الاتصــال

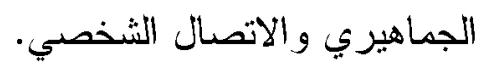

الثالث: فهو بديل نفسي اجتماعي يهدف إلى تحديد كيفية تأثير الاتصــال الجمـاهيري على الأشخاص نفسيًا، واجتماعيًا، وتئقافيًا.

وتنطلق الدر اسـة من بعض فروض نظرية الاعتماد على وســائل الإعـلام وخاصــة

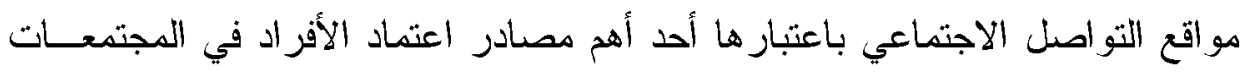

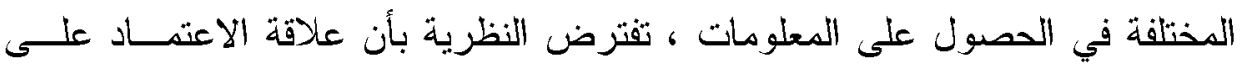

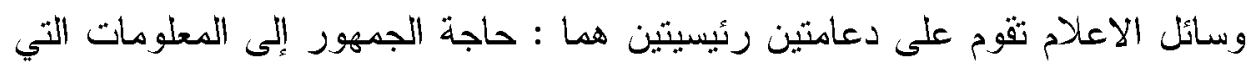

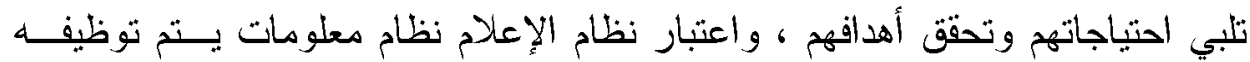

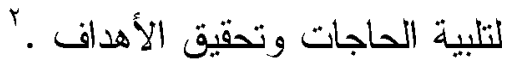

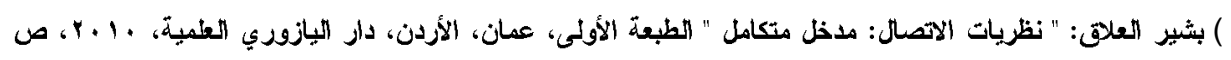
vr

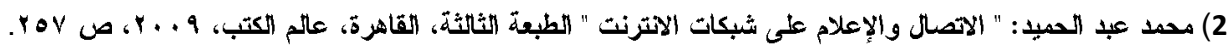




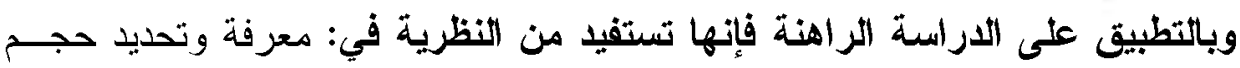

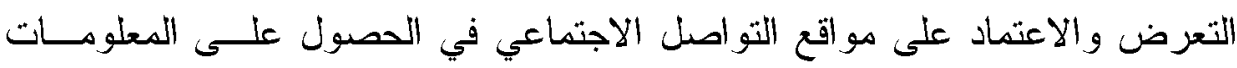

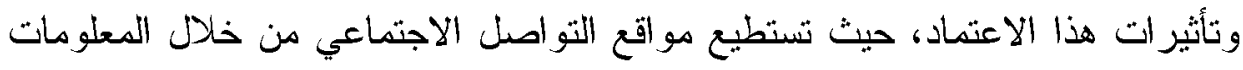

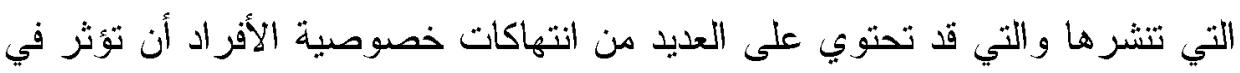

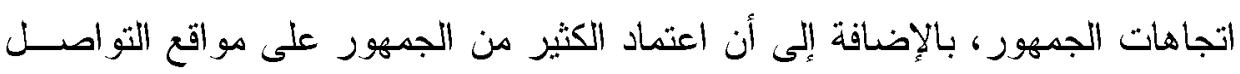
الاجتماعي كمدر للمعلومات ترتب عليه جعلها مصدر لانتهاك الخصوصية الرقات الرقية.

\section{خامساً: إجراءات الدراسة}

مجتمع وعينة الاراسة

(أ) يتمثيل مجتمع الاراسة في: الجمهور العربي.

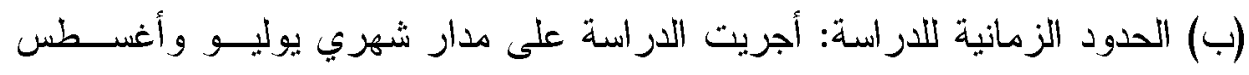
.$r \cdot Y$

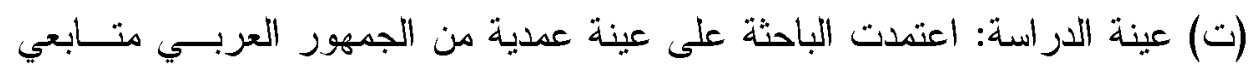

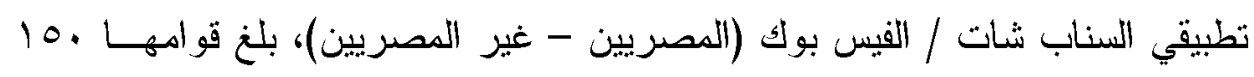

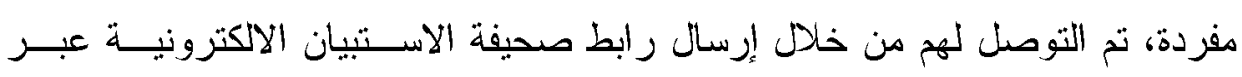

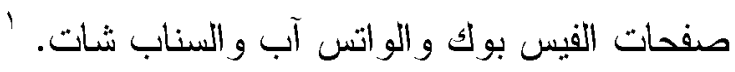

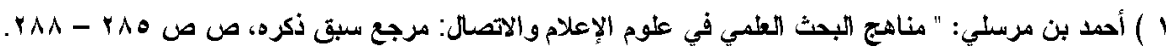
rᄉ 


$$
\text { (ج) خصائص عينة الار اسة: }
$$

1 - توزيع عينة الدراسة وفقاً للنوع : ويبينها الثكل التالي :

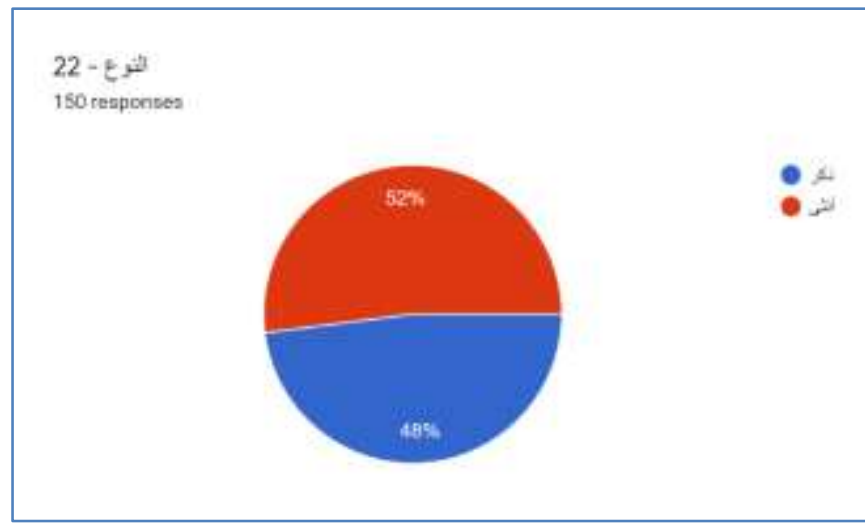

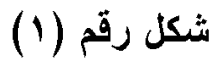

توزيع عينة الدراسة وفقاً للنوع

r - توزيع عينة الاراسة وفقاً للمؤهل التعليمي :ـويبينها الثكل التالي :

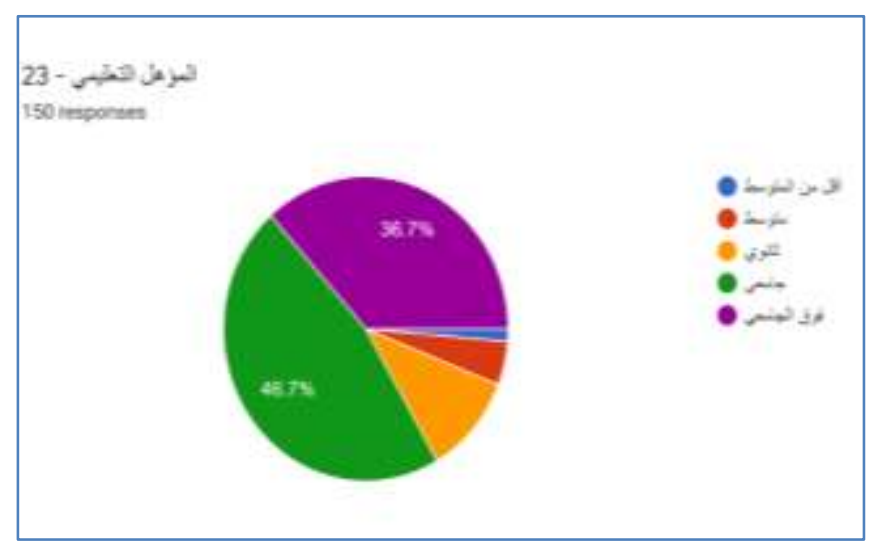

شكل رقم (Y)

توزيع عينة الدراسة وقةًا للمؤهل التعليمي 
ب - توزيع عينة الاراسة وفقا للفئة العمرية : ويينها الثكل التالي :

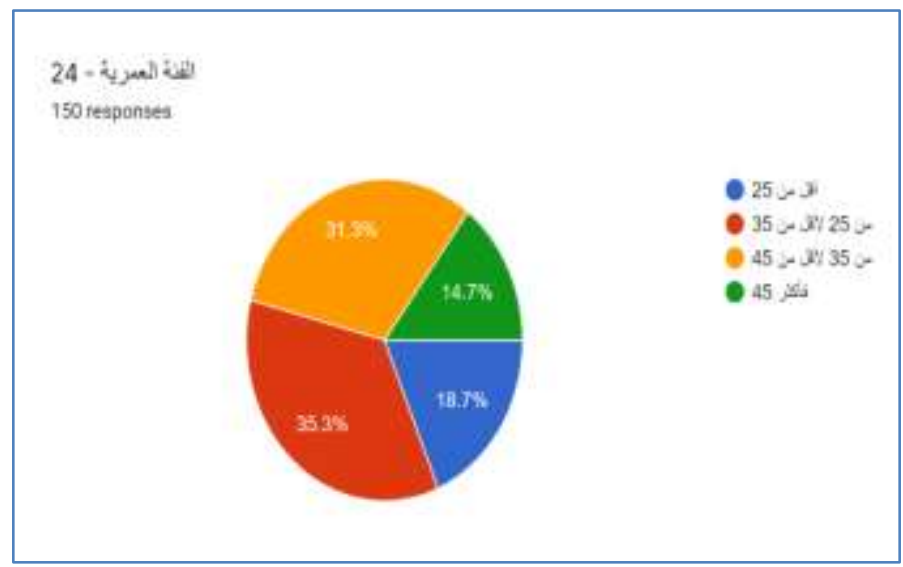

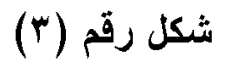

توزيع عينة الدراسة وفقاً للفئة العمرية

ع - توزيع عينة الاراسة وفقا للحالة الاجتماعية:ويبينها الثكل التالي:

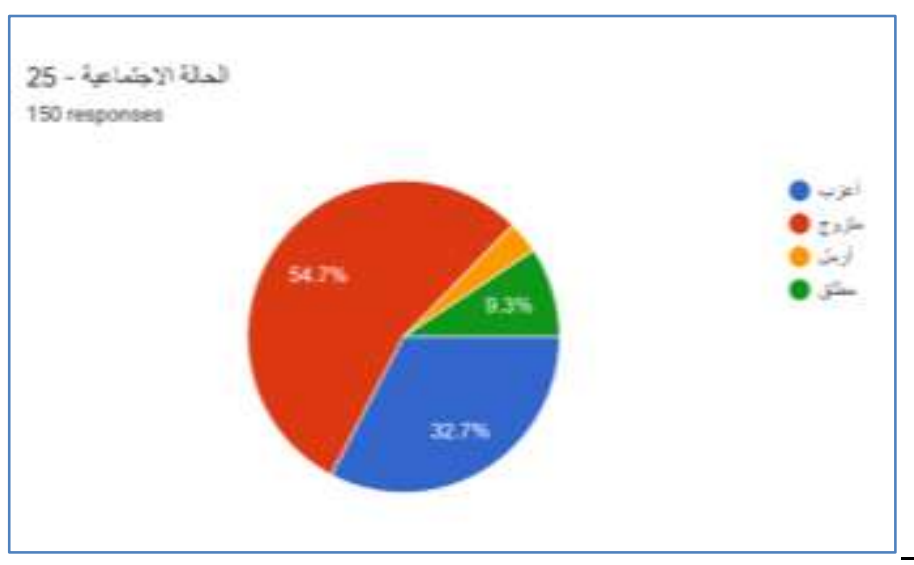

شكل رقم (ع)

توزيع عينة الاراسة وفقًا للحالة الاجتماعية

r. 
ه - توزيع عينة الاراسة وفقاً للوظيفة :ويبينها الشكل التالي :

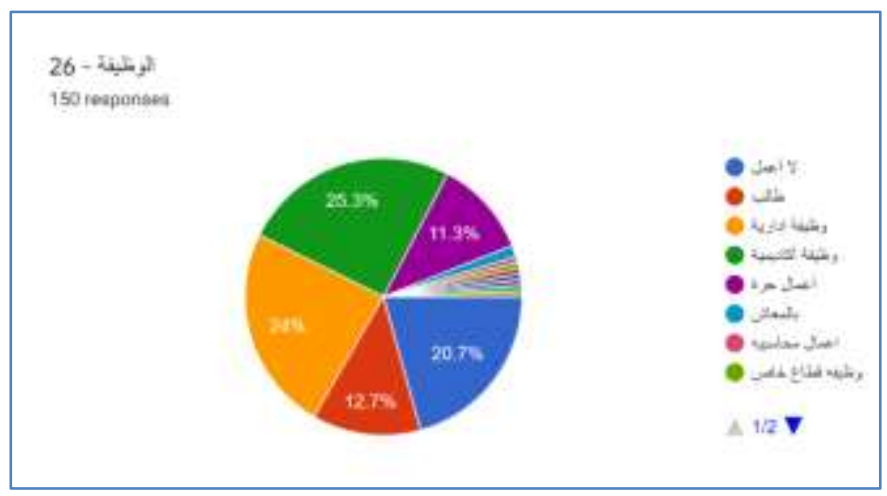

شكل رقم (0)

توزيع عينة الاراسة وفقًا للوظيفة رهية

7 - توزيع عينة الاراسة وفقاً للجنسبة : ويبينها الشكل التالي :

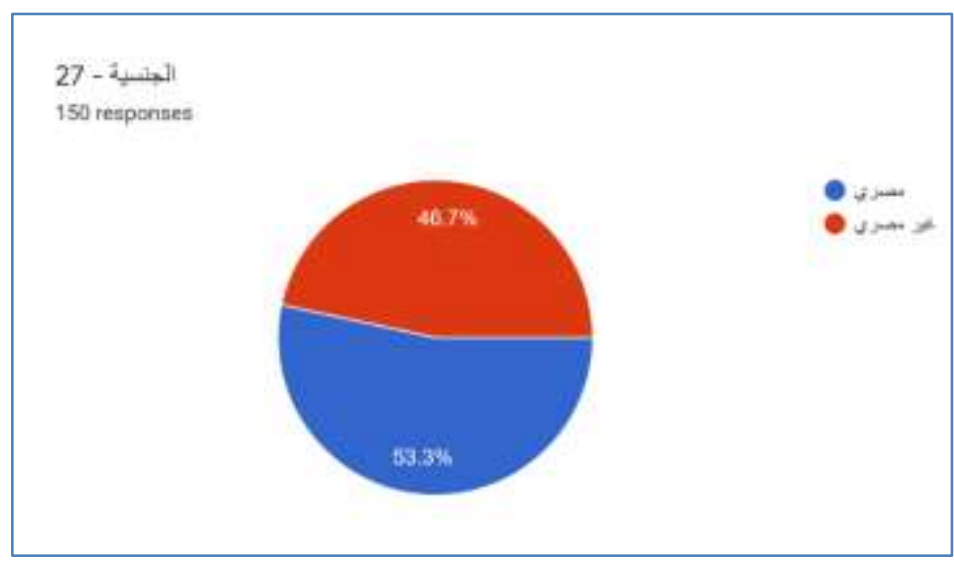

شكل رقم (7)

توزيع عينة الدراسة وفقًا للجنسية 
تهـف الدراسة الى الإجابة على تساؤلات الدراسة وبيان العلاقــات الإرتباطيــة بـين

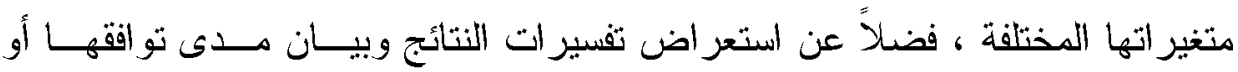
تعارضها مع نتائج الدراسات السابقة ، وذللك على النحو الآتي : -

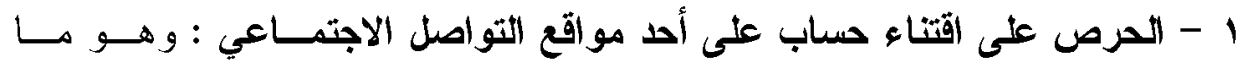

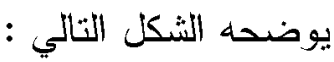

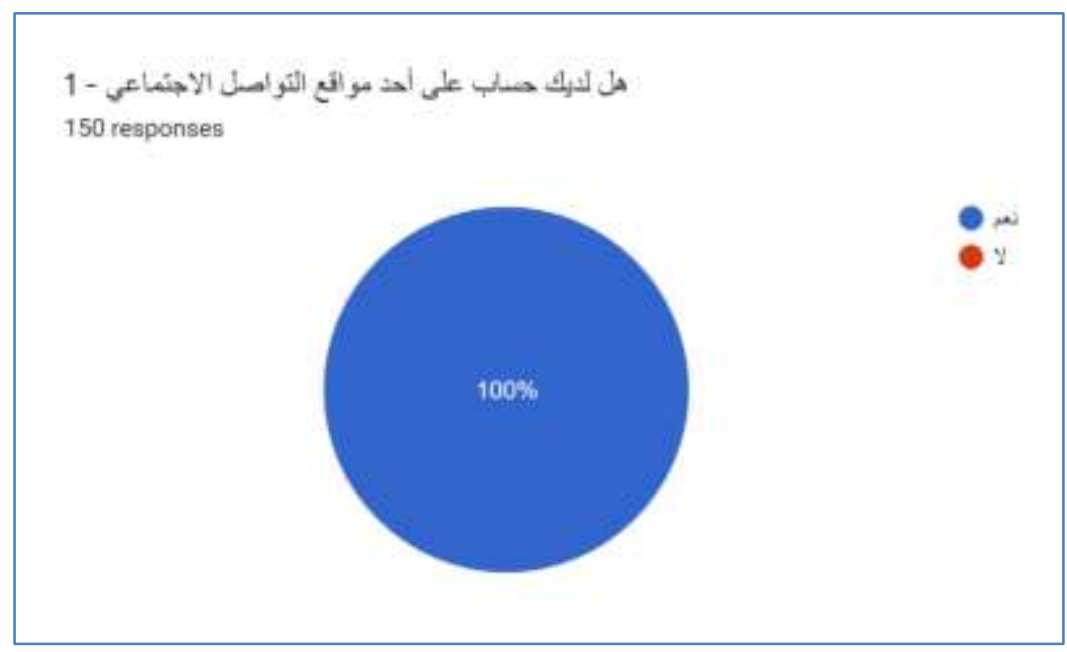

(v) تشكل رقم

الحرص على اقتناء حساب على أحد مواقع التواصل الاجتماعي

توضح بيانات الثكل السابق مايثي : أوضحت نتائج الاراسة الميدانية حرص واهتمام الجمهور باقتتاء حساب علـى أحسـ

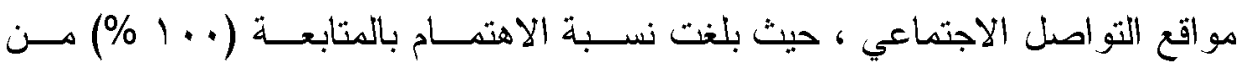

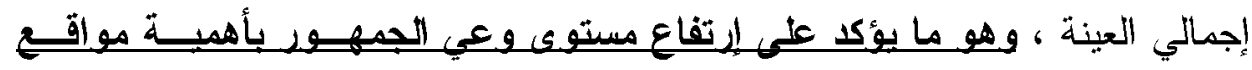
التواصل الإجتماعي 
r - التعلاقة بين الجنسية و أكثر مواقع التواصل الاجتماعي متابعة لاى الجمهـور : وهو ما يوضحه الجدول الآتي :

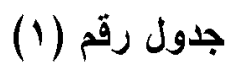

العلاقة بين الجنسية و أكثر مواقع التواصل الاجتماعي متابعة لاى الجمهور

\begin{tabular}{|c|c|c|c|c|c|c|c|c|c|c|c|}
\hline \multirow[t]{3}{*}{ الدلالة } & \multirow{3}{*}{ المعنوية } & \multirow[t]{3}{*}{ SL } & \multirow[t]{3}{*}{ العجموع } & \multicolumn{6}{|c|}{ الترتيب } & \multirow[t]{3}{*}{ الجنسية } & \multirow{3}{*}{ الاجتمابع مواصع } \\
\hline & & & & 7 & • & $\varepsilon$ & $r$ & $r$ & 1 & & \\
\hline & & & & ك & s & ك & s & ك5 & ك & & \\
\hline \multirow[t]{2}{*}{ دالة } & \multirow[t]{2}{*}{0.000} & \multirow{2}{*}{ 38.922a } & \multirow[t]{2}{*}{10.} & 1 & 1 & 3 & 2 & 12 & 61 & مصري & \multirow{2}{*}{ بوكث } \\
\hline & & & & 25 & 5 & 4 & 2 & 7 & 27 & غصري & \\
\hline \multirow[t]{2}{*}{ دالة } & \multirow[t]{2}{*}{0.000} & \multirow[t]{2}{*}{$39.943 a$} & \multirow[t]{2}{*}{10.} & 23 & 10 & 10 & 8 & 19 & 10 & مصري & \multirow{2}{*}{ شات } \\
\hline & & & & 3 & 3 & 3 & 2 & 25 & 34 & مصري & \\
\hline \multirow{2}{*}{ غالةير } & \multirow[t]{2}{*}{0.100} & \multirow[t]{2}{*}{ 9.235a } & \multirow[t]{2}{*}{10.} & 7 & 4 & 12 & 28 & 23 & 6 & مصري & \multirow{2}{*}{ الانستجرا } \\
\hline & & & & 5 & 2 & 3 & 25 & 21 & 14 & مصري & \\
\hline \multirow[t]{2}{*}{ غيلة } & \multirow[t]{2}{*}{0.793} & \multirow[t]{2}{*}{$2.391 \mathrm{a}$} & \multirow[t]{2}{*}{10.} & 3 & 9 & 19 & 16 & 15 & 18 & مصري & \multirow[t]{2}{*}{ اليوتيوب } \\
\hline & & & & 4 & 13 & 17 & 11 & 12 & 13 & مصري & \\
\hline \multirow{2}{*}{ غالة } & \multirow[t]{2}{*}{0.183} & \multirow[t]{2}{*}{$7.549 a$} & \multirow[t]{2}{*}{10.} & 34 & 18 & 18 & 4 & 1 & 5 & مصري & \multirow[t]{2}{*}{ لنكد ان } \\
\hline & & & & 40 & 17 & 6 & 2 & 0 & 5 & مصرير & \\
\hline \multirow{2}{*}{ غالةير } & \multirow[t]{2}{*}{0.550} & \multirow[t]{2}{*}{$3.996 \mathrm{a}$} & \multirow[t]{2}{*}{10.} & 13 & 17 & 22 & 16 & 4 & 8 & مصري & التليجرام \\
\hline & & & & 13 & 9 & 19 & 12 & 8 & 9 & مصري & \\
\hline
\end{tabular}

توضح بيانات الجدول السابق ما يلي: -

أوضحت نتائج الاراسة علم وجود علاقــة دالــة إحصــائياً بـين جنسـية

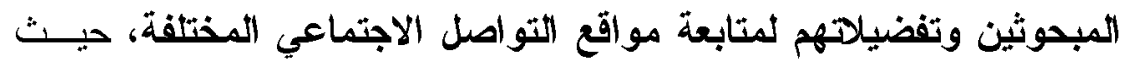

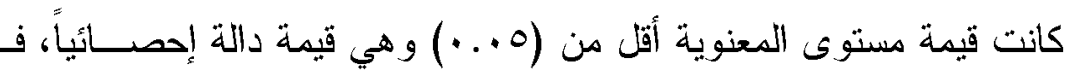

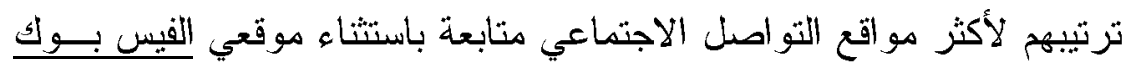
rT 
و السناب شات - النماذج التطبيقية التي أجريت عليها الدراسة- حيث أكـدت

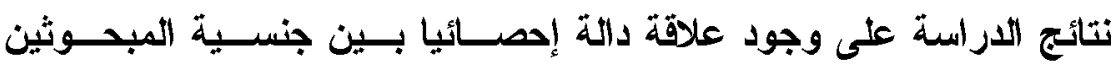
(مصري-غير مصري) وترتيبهم لمتابعة موقعي الفيس بوك والسناب شات. بالنسبة لعينة المصريين : جاء موقع الفيس بوك في الترتيبي الأول والثاني

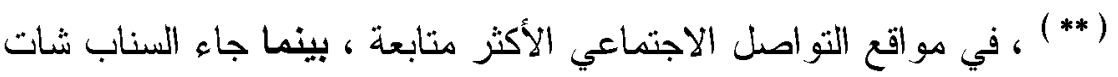
في الترتيب السادس لدى أفر اد عينة المصريين في المتابعة.

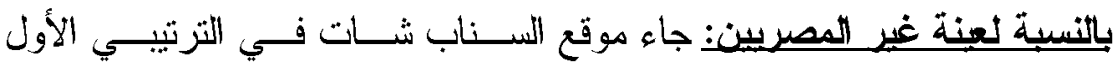

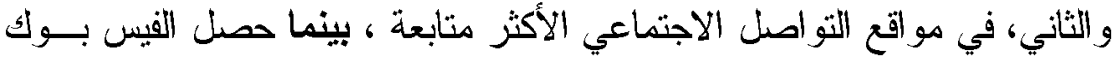
على الترتيبي الأول و السادس لدى لؤ أفراد عينة غير المصريين في المتابعة. وهو ما يتفق مي نتائج الأراسات سابقة حيث أكلات دراســة (عبـد النبـي

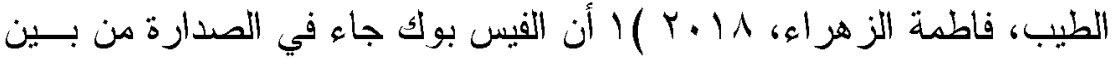

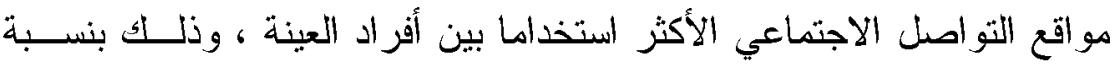
(\%) من أفراد العينة.

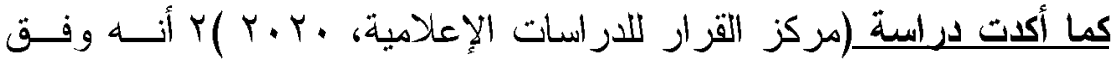

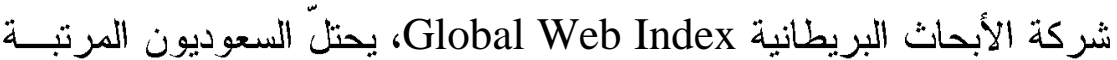

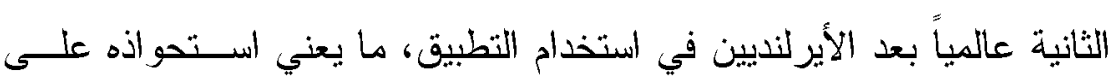

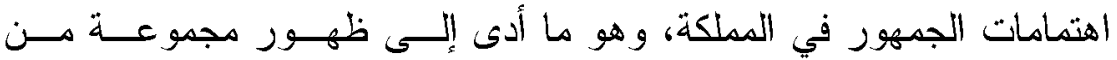

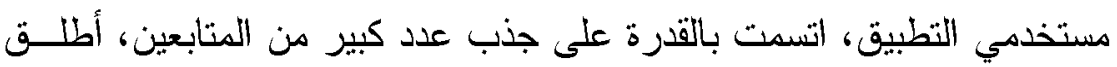
عليهم مشاهير سناب شات

$$
\text { ' ( ) ( ) في الترتيب تعني الأكثر متابعة و ( } 1 \text { ( ) الأقل متابعة. }
$$

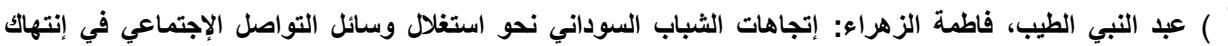

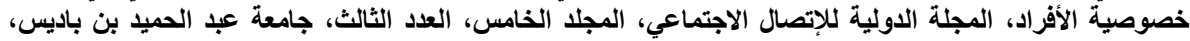

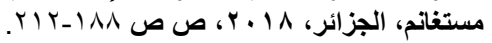

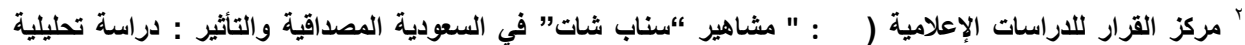
-5-2021. 29available on line @ https://alqarar.sa/1410 , access on ," 


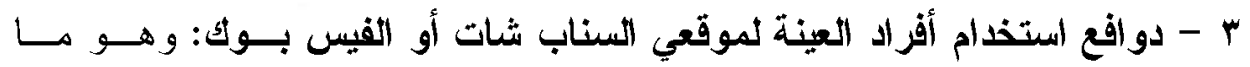
يوضحه الجدول الآتي :

جدول رقم (r) (r) (r)

دوافع استخدام أفراد العينة لموقعي السناب شات أو الفيس بوك

\begin{tabular}{|c|c|c|}
\hline$\%$ & ك & الدوافع \\
\hline 14.7 & 22 & التسلية والاستمتاع \\
\hline 7.3 & 11 & قضاء وقت الفراغ \\
\hline 4.7 & 7 & بناء علاقات اجتماعية جديدة مع الآخرين \\
\hline 4.7 & 7 & التعبير عن أفكاري ومشاعري ومشاركتها مع الآخرين \\
\hline 10.7 & 16 & التواصل مع الأصدقاء والأقارب \\
\hline 54.7 & 82 & 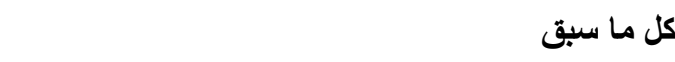 \\
\hline 3.3 & 5 & أخرى تذكر \\
\hline $1 \ldots$ & 10. & الإجمالي \\
\hline
\end{tabular}

توضح بيانات الجدول السابق مايلي:

أكدت نتائج الدراسة على تعدد دوافع استخدام الجمهور العربي-عينة الدراسة- لمواقع

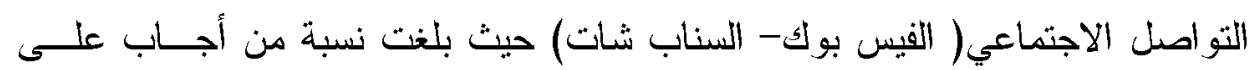

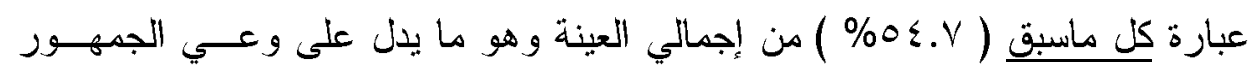
بدو افع استخدامه ومتابعته لمواقع التو اصل الاجتماعي ، بينما حدد عدد من أفراد العينة

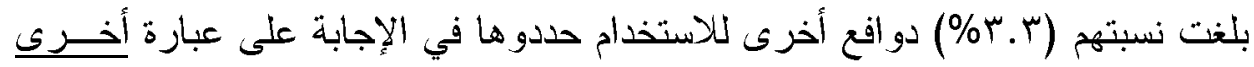

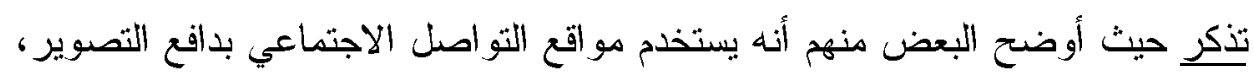

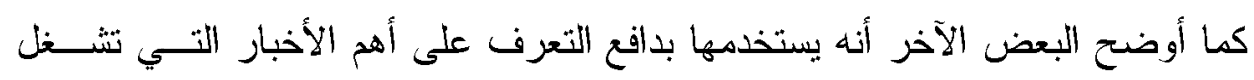
الناس، و البعض الآخر يستخدمها بدافع البحث عن فرص شرائية معينة. 
؛ - العلاقة بين النوع ودوافع استذدام أفراد العينة لموقعي السناب شات أو الفيس بوك: وهو ما يوضحه الجدول الآتي:

$$
\text { جدول رقم (") }
$$

العلاقة بين النوع ودوافع استخدام أفراد العينة لموقعي السناب شات أو الفيس بوكى

\begin{tabular}{|c|c|c|c|}
\hline \multirow[t]{2}{*}{ 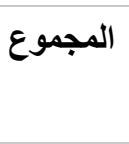 } & \multicolumn{2}{|c|}{ 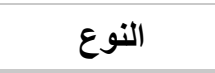 } & \multirow[t]{2}{*}{ الدوافع } \\
\hline & أنثى & ذكر & \\
\hline s & ك & ك & \\
\hline rr & 10 & v & التسلية والاستمتاع \\
\hline 11 & - & 1 & قضاء وقت الفراغ \\
\hline v & $r$ & $\varepsilon$ & بناء علاقات اجتماعية جديدة مع الآخرين \\
\hline v & - & r & الآخريين عن أفكاري ومشاعري ومشاركتها مع \\
\hline 19 & $\mathrm{v}$ & a & التواصل مع الأصدقاء والاقارب \\
\hline Ar & rq & $\varepsilon r$ & كل ما سبق \\
\hline . & $\varepsilon$ & 1 & أخرى تنكر \\
\hline 10. & va & vr & الإجمالي \\
\hline
\end{tabular}

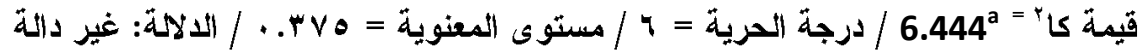

توضح بيانات الجدول السابق ما يلي: عدم وجود علاقة دالة إحصائياً بين نوع المبحوثين ودوافع استخدامهم لموقعي

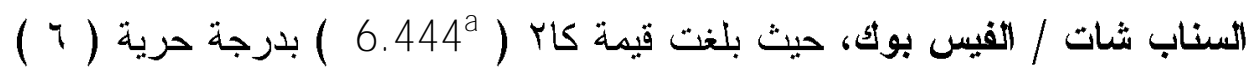

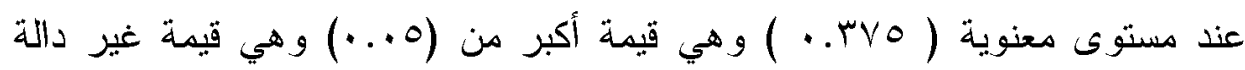

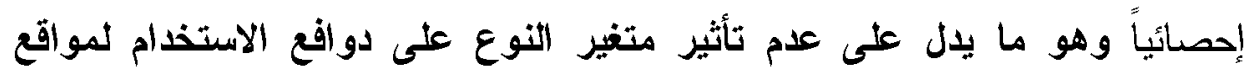
التواصل الاجتماعي لاى أفراد العينة. 
ه - الفترة الزمنية وعدد الساعات التي يقضيها الجمهور في متابعة السناب شات أو الفيس بوك: وهو ما يوضحه الجدول الآتي :

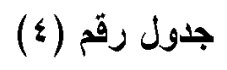
الفترة الزمنية وعدد الساعات التي يقضيها الجمهور في متابعة السناب شات أو الفيس بوثك

\begin{tabular}{|c|c|c|c|}
\hline$\%$ & ك & الاختيار & \\
\hline 54.7 & 82 & يوميا & \multirow{4}{*}{ الفترة الزمنية } \\
\hline 6.7 & 10 & من يوم ل r أيام في الأسبوع & \\
\hline 8.7 & 13 & أكثر من ץ أيام في الأسبوع & \\
\hline 30.0 & 45 & حسب الظروف & \\
\hline 38.7 & 58 & أقل من ساعة & \multirow{3}{*}{ عدد الساعات } \\
\hline 34.0 & 51 & من ساعة إلى ץ ساعات & \\
\hline 27.3 & 41 & أكثر من ץ ساعات & \\
\hline $1 \ldots$ & 10. & الإجمالي & \\
\hline
\end{tabular}

توضع بيانات الجدول السابق مايلي: حرص الجمهور على متابعة موقعي الفيس بؤك والسناب شات بشكل يومي حيث بلغت نسبة أفراد العينة الحريصين على متابعة مستجدات كورونا بشكل يومي ولئي ، وهو ما يدل على وعي الجمهور بأهمية التعرف على مستجدات الجائحة (\%)

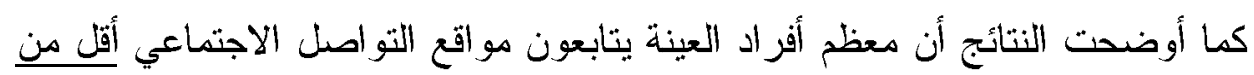

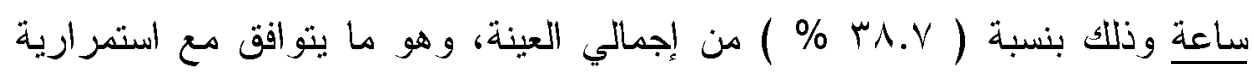

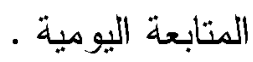


7 - عدد الأصدقاء المضافين على صفحة المبحوث على السناب شات أو الفيس بوثك :وهو ما يوضحه الثكل الآتي :

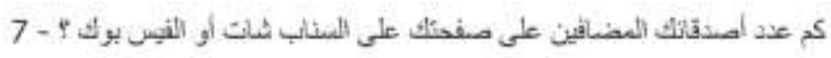

150 responses

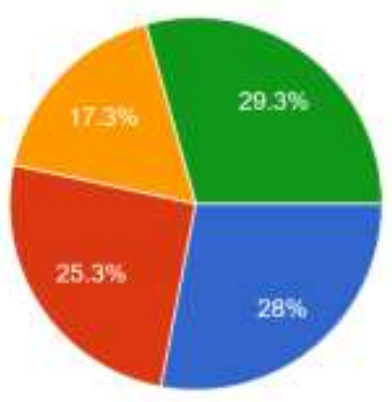

شكل رقم (^)

عدد الأصدقاء المضافين على صفحة السناب شات / الفيس بوثك للمبحوثين

توضح بيانات الثكل السابق مايلي: -

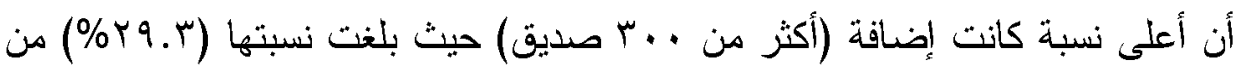
إجمالي العينة، تلاها وبفارق بسيط نسبة إضافة (أقل من . ․ صديق) وذلك بنسبة (\% \% )

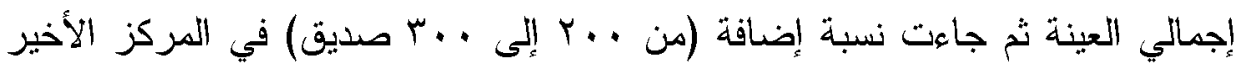
بنسبة (YV.T\%) من إجمالي العينة، وهو ما يؤكد على إهتمام الجمهور بإضافة الأصدقاء على حساباتهر. 
كما أكلات العديد من الاراسات عثلى أن عدد الأصدقاء على حسابات مواقع التو اصل

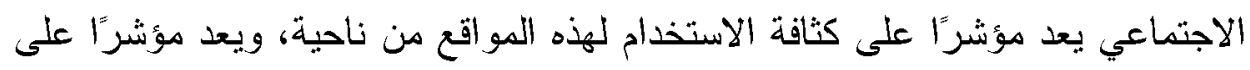
للعديد من الظو اهر المرتبطة بأنشطة الأفر اد على هذه المو اقع من ناحية أخرى الخدى. V - الأثشطة التي يقوم بها أفراد العينة على السناب شات أو الفيس بوك: وهو ما

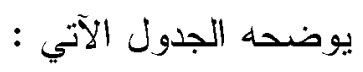

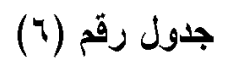

\begin{tabular}{|c|c|c|}
\hline \multicolumn{3}{|c|}{ الأشطة التي يقوم أفزاد العينة على السناب شات أو الفيس بوك } \\
\hline 17.3 & 26 & الفيس بوكة قصص الأصدقاء الشخصية على السناب شات أو \\
\hline 12.7 & 19 & المحادثة مع الأصدقاء سو اء بالكتابة أو بالصوت أو بالفيديو \\
\hline 3.3 & 5 & الفيس قصوكي الثخصي على صفحتي على السناب شات أو \\
\hline 6.0 & 9 & تحديث بروفايلي الشخصي باستمر ار \\
\hline 7.3 & 11 & الأحدر صورت والفعاليات الثخبة أثناء مشاركتي في العديد من \\
\hline 3.3 & 5 & العديد عدن مجالات الحياة و القصص المفيدة المتنوعة في \\
\hline 48.0 & 72 & نشين العديد من القصص و المعلومات المتخصصة في مجال \\
\hline IV.r & Y & كل ما سبق \\
\hline 2.0 & 3 & أخرى تذكر \\
\hline $1 \cdots$ & 10. & الإجمالي \\
\hline
\end{tabular}

توضح بيانات الجدول السابق مايلي:

أن أكثر الأنشطة التي يقوم بها أفراد العينة على السناب شات و الفيس بوك هي نثـــر

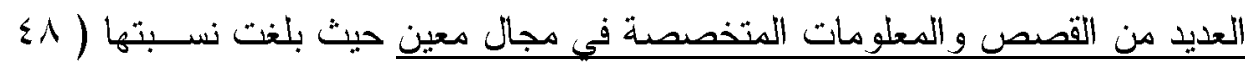
\% ) تلاها متابعة تصص الأصدقاء الثخصية على السناب شات أو الفيس بوك وذلك ولك بنسبة ( V.T \% IV ) وتساوت معها في النسبة القيام بكل الأنشطة بينما جاء في المركز 


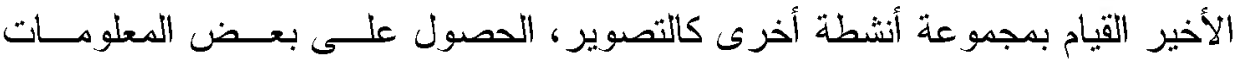

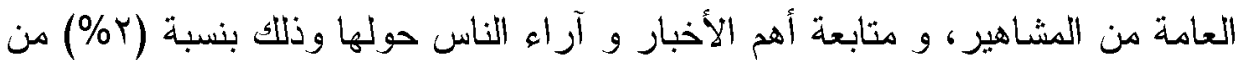
إجمالي أفراد العينة، وهو ما يدل على وعي الجمهور بما يقوم بـه من أنثــطة أثنــاء استخدامه لموقعي الفيس بو كك و السناب شات.

1 - العلاقة بين النوع والأنشطة التي يقوم بها أفراد العينة على السناب شات أو الفيس بوك: وهو ما يوضحه الجدول الآتي: جدول رقم (v)

العلاقة بين النوع والأنشطة الثي بقوم بها أفراد العبنة على السناب شات أو الفيس بوك

\begin{tabular}{|c|c|c|c|}
\hline \multirow[t]{2}{*}{ المجموع } & \multicolumn{2}{|c|}{ النوع } & \multirow[t]{2}{*}{ الأنثطة } \\
\hline & أنثى & ذكر & \\
\hline ك & ك & ك & \\
\hline rq & $1 \leqslant$ & ir & ثنات أو الفيس بوك الأصدقاء الثخصية على السناب \\
\hline 19 & ir & 9 & بالفيديوثة مع الأصدقاء سو اء بالكتابة أو بالصوت أو \\
\hline • & $\varepsilon$ & 1 & ثنات أو الفيسي بوك الثخي على صفحتي على السناب \\
\hline . & - & - & تحديث بروفايلي الثخصي باستمر ار \\
\hline$q$ & $\varepsilon$ & • & نشر صنوري الثخاث والفعالياتية أثناء مشاركتي في العديد \\
\hline 11 & 9 & r & 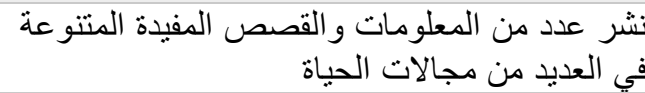 \\
\hline - & $\varepsilon$ & 1 & في مجال معين من القصص و المعلومات المتخصصة \\
\hline VY & rA & ๕ & كلَ ما سبق \\
\hline r & r & 1 & أخرى تذكر \\
\hline 10. & $\vee \wedge$ & Vr & الإجمالي \\
\hline
\end{tabular}


توضح بيانات الجدول السابق ما يبي: -

وجود علاقة دالة إحصائياً بين نوع المبحوثين والأثثطة التي يقوموا بها على موقعي السناب شات / الفيس بوك، حيث بلغت ثيمة كاب ( 14.571a) بدرجة

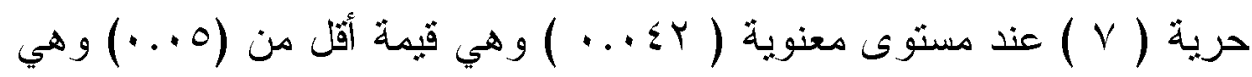
ثيمة دالة إحصائياً وهو ما بدل على نأثير منغير النوع على نوعية الأنشطة الني يقوم بها أفر اد العينة أثناء استخدامهح لموقعي الفيس بوك و السناب شات.

9 - ادر الك الجمهور لمفهوم الخصوصية الرقمية: وهو ما يوضحه الجدول الآتي:

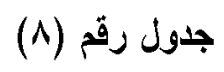

إدراثك الجمهور لمفهوم الخصوصية الرقمية

\begin{tabular}{|c|c|c|}
\hline$\%$ & ك & المفهوم \\
\hline 23.3 & 35 & وتداولها من خلال وسائط رقمية الثيات الثصية للفرد، و التي يتم نشرها \\
\hline 5.3 & 8 & الآخر التيني تَحَمَم الأفر اد في مدى وتوقيت وظروف مشاركة حياتهم مع \\
\hline 18.0 & 27 & 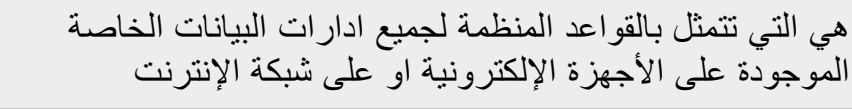 \\
\hline 52.0 & 78 & كل ما سبق \\
\hline 1.3 & 2 & أخرى تذكر \\
\hline $1 \ldots$ & 10. & الإجمالي \\
\hline
\end{tabular}

توضـح بيانات الجدول السابق: 
ارتفاع إدر الك الجمهور لـفهوم الخصوصية الرقمية حيث بلغت نسبة المبحوثين اللــذين

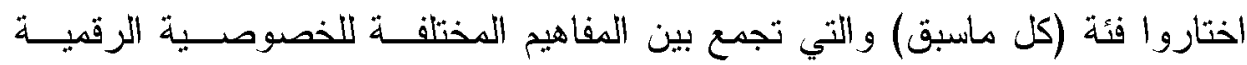

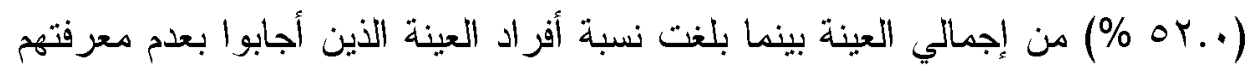

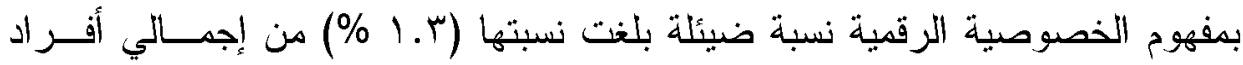

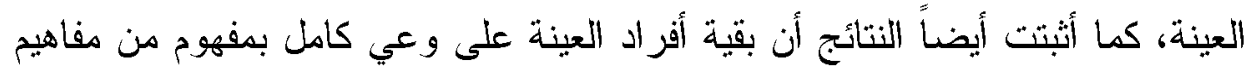

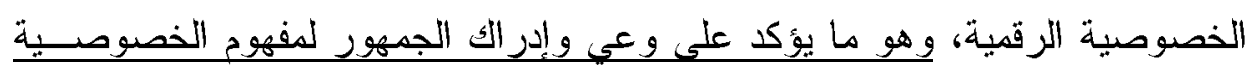
الرقمية. . 1 - إدراك الجمهور لصور انتهاك الخصوصية الرقمية: وهو ما يوضحه الجدول الآتي: جدول رقم (9)

إلدرالك الجمهور لصور انتهاك الخصوصية الرقمية

\begin{tabular}{|c|c|c|}
\hline$\%$ & ك & المفهوم \\
\hline 10.7 & 16 & 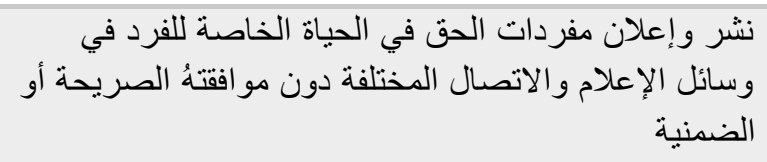 \\
\hline 8.0 & 12 & أشخاص غير مرخص فهم البيانات الثخصية أو محو ها عن طريق \\
\hline 15.3 & 23 & 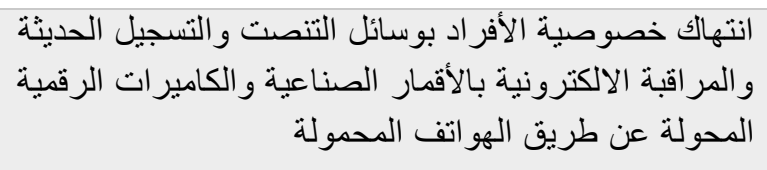 \\
\hline 64.7 & 97 & كل ما سبق \\
\hline 1.3 & 2 & أخرى تذكر \\
\hline $1 \ldots$ & 10. & الإجمالي \\
\hline
\end{tabular}
توضع بيانات الجدول السابق: 
ارتفاع إدر الك الجمهور لصور انتهاك الخصوصية الرقمية حيـث بلغــت نسـبـة

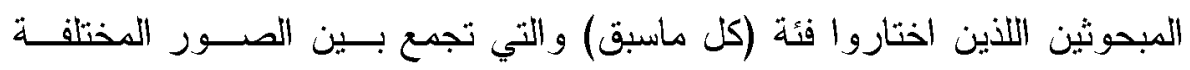

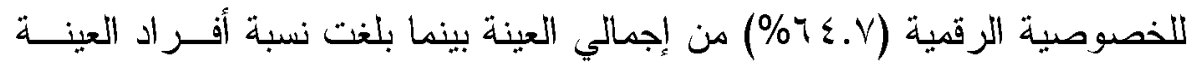

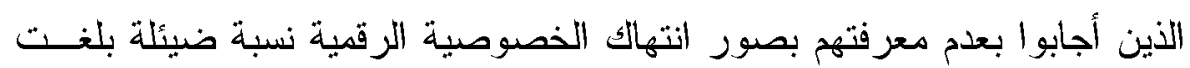

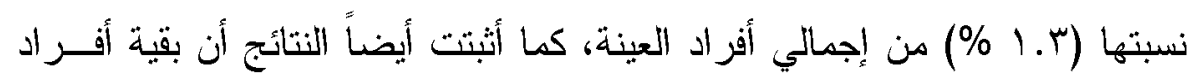

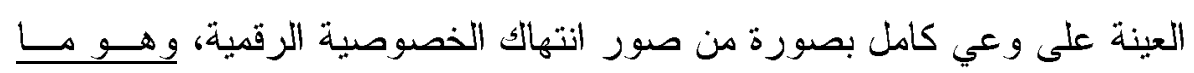
يؤكد على وعي وإدر الك الجمهور بصور انتهاك الخصوصية الزقمية.

11 - اتجاهات الجمهور نحو التعامل مع إعدادات الأمسـان الخاصــة بمــوقعي السناب الثنات / الفيس بوثى : وهو ما يوضحه الجدول الآتي :

$$
\text { جدول رقم (1.) }
$$

اتجاهات الجمهور نحو التعامل مع إعدادات الأمان الخاصة بموقعي السناب الشات / الفيس بوك

\begin{tabular}{|c|c|c|c|c|c|c|c|c|c|c|}
\hline \multicolumn{10}{|c|}{ الاتجاه } & \multirow[t]{3}{*}{ العبارة } \\
\hline \multicolumn{2}{|c|}{ معارض بشدة } & \multicolumn{2}{|c|}{ معارض } & \multicolumn{2}{|c|}{ محايد } & \multicolumn{2}{|c|}{ مو افق } & \multicolumn{2}{|c|}{ مو افق بشدة } & \\
\hline$\%$ & ك & $\%$ & ك & $\%$ & كs & $\%$ & كs & $\%$ & ك & \\
\hline 3.3 & 5 & 7.3 & 11 & 24.0 & 36 & 30.7 & 46 & 34.7 & 52 & 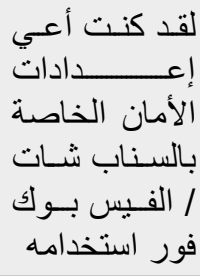 \\
\hline .7 & 1 & 3.3 & 5 & 13.3 & 20 & 36.7 & 55 & 46.0 & 69 & 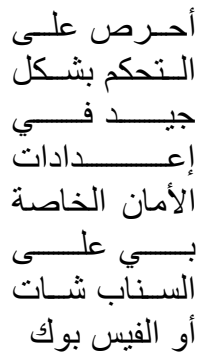 \\
\hline
\end{tabular}




\begin{tabular}{|c|c|c|c|c|c|c|c|c|c|c|}
\hline$\because \cdot$ & $\because \cdot$ & 8.0 & 12 & 24.7 & 37 & 32.7 & 49 & 34.7 & 52 & 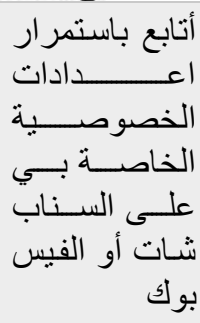 \\
\hline 13.3 & 20 & 10.0 & 15 & 25.3 & 38 & 34.0 & 51 & 17.3 & 26 & 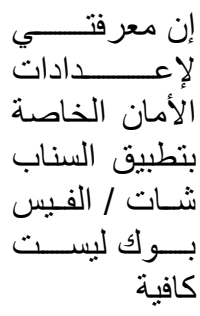 \\
\hline 28.0 & 42 & 22.0 & 33 & 15.3 & 23 & 17.3 & 26 & 17.3 & 26 & 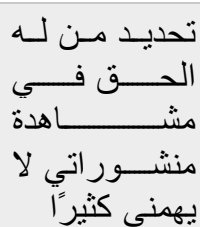 \\
\hline 31.3 & 47 & 21.3 & 32 & 16.0 & 24 & 16.0 & 24 & 15.3 & 23 & 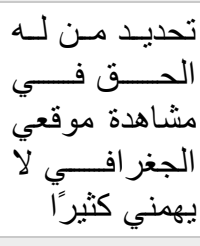 \\
\hline & & & & & & & & & 10. & الإجمالي \\
\hline
\end{tabular}

توضح بيانات الجدول السابق:

تفوق الاتجاهات الإيجابية للجمهور في التعامل مع إعــادات الأمسـان الخاصــة

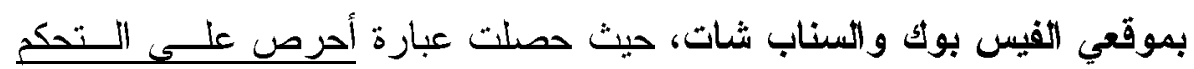

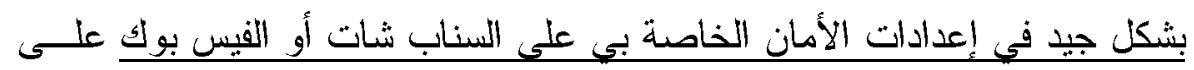

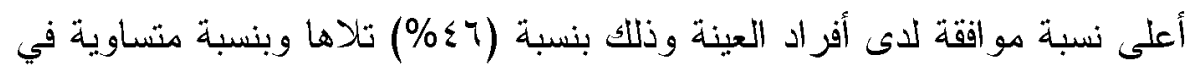

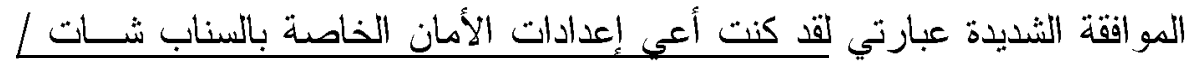
الفيس بوك فور استخدامه، أتابع باستمر ار اعدادات الخصوصية الخاصة بي على 


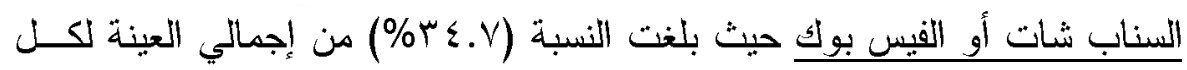
عبارة، وهو ما يال على وعي الجمهور بأهمية اتخاذ كافة إجراءات الأمان أثناء التعامل مع مواقع التواصل الاجتماعي.

r ا - اتجاهات الجمهور نحو مدى التعرض لاتتهاكات الخصوصية عبر مــوقعي السناب الثات / الفيس بوكى : وهو ما يوضحه الجدول الآتي :

$$
\text { جلول رثم (11) }
$$

اتجاهات الجمهور نحو مدى التعرض لاتتهاكات الخصوصية عبر موقعي السناب الثات / | الفيس بون

\begin{tabular}{|c|c|c|c|c|}
\hline \multicolumn{4}{|c|}{ الاتجاه } & العبارة \\
\hline \multicolumn{2}{|c|}{$y$} & \multicolumn{2}{|c|}{ نعم } & \\
\hline$\%$ & ك5 & $\%$ & ك & \\
\hline 57.3 & 86 & 42.7 & 64 & لقد تعرض الفيس بوكـ للسرقة / حسـاب أحد أصدقائي على السناب \\
\hline 58.0 & 87 & 42.0 & 63 & 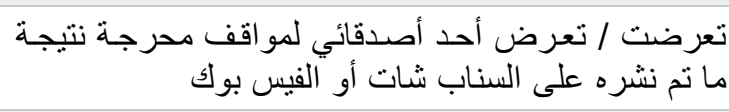 \\
\hline 74.0 & 111 & 26.0 & 39 & 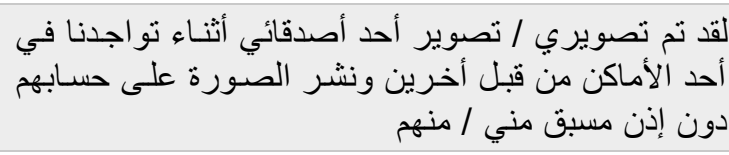 \\
\hline 72.0 & 108 & 28.0 & 42 & 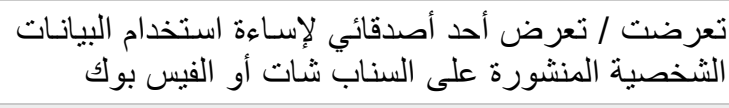 \\
\hline 61.3 & 92 & 38.7 & 58 & لأذى أو / حرج لنا أو للآخرقيني صـور أو فيديوهات تسبيت \\
\hline 42.7 & 64 & 57.3 & 86 & تعد ذلك أنهم / تُشخرض أحد هميين أصدقي لإضـافة أنشخاص اتضـح \\
\hline & & & 10. & الإجمالي \\
\hline
\end{tabular}


أكدت نتائج الدراسة على أن النسبة الأعلى لمدى تعرض أفراد العينة لانتهاكـات

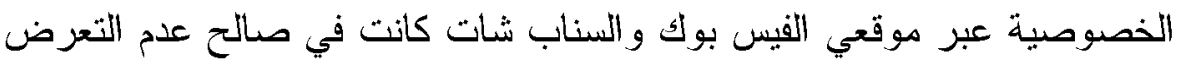

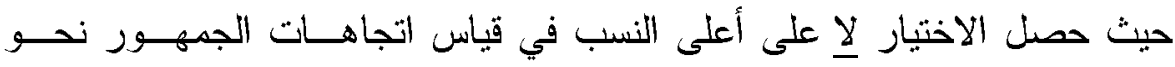

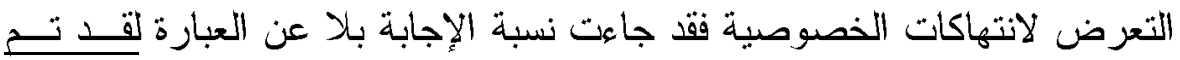

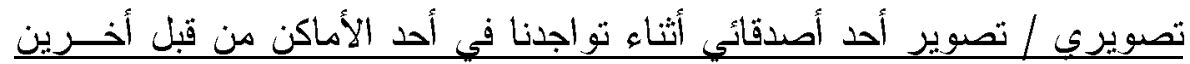

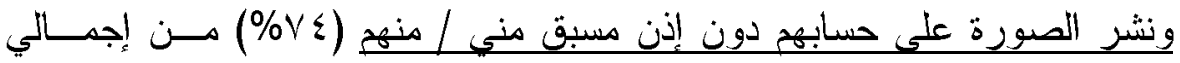

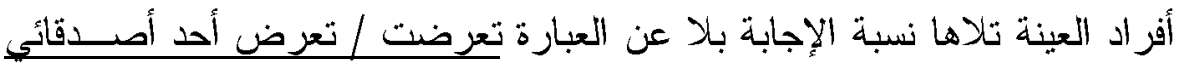

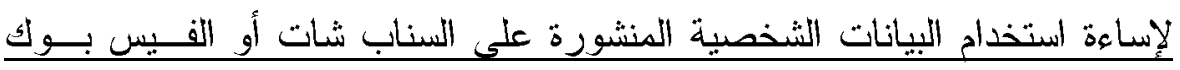
و التي بلغت (\%VY) من إجمالي أفراد العينة، ثم نسبة الإجابة بلا عـن العبـارة

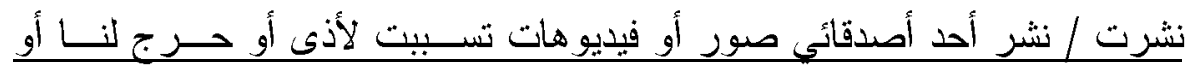

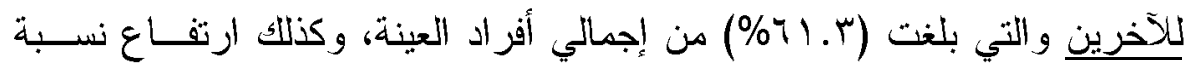
الإجابة بلا لدى أفراد العينة على العبارات التي تعبر عن مدى تعرض الجمهـئور لانتهاكات الخصوصية المختلفة، وهو ما يتوافق مع النتائج التي أثبتتها الدراسة لهئ الراهنة حيث أكدت على وعي الجمهور بأهمية اتخاذ كافة إجراءات الأمان أثناء التعامل مع مواقع التواصل الاجتماعي. 
r 1 - طبيعة استخدامات الجمهور لموقعي السناب الثات / الفيس بوكك: وهو ما

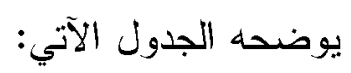

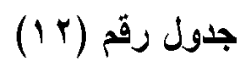

طبيعة استخدامات الجمهور لموقعي السناب الشات / الفيس بوك (1أك

\begin{tabular}{|c|c|c|c|c|c|c|}
\hline \multicolumn{6}{|c|}{ الاتجاه } & \multirow[t]{3}{*}{ 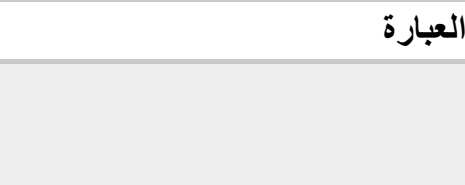 } \\
\hline \multicolumn{2}{|r|}{ أبدا } & \multicolumn{2}{|r|}{ 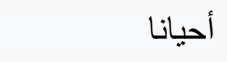 } & \multicolumn{2}{|r|}{ دائما } & \\
\hline$\%$ & كs & $\%$ & ك & $\%$ & ك & \\
\hline 19.3 & 29 & 54.7 & 82 & 26.0 & 39 & 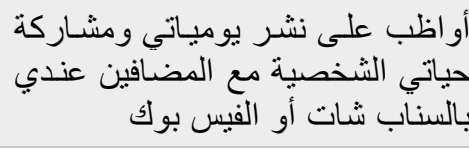 \\
\hline 24.7 & 37 & 48.7 & 73 & 26.7 & 40 & 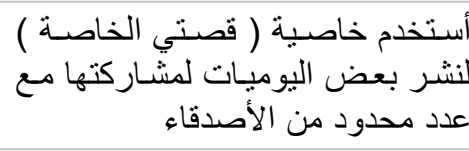 \\
\hline 21.3 & 32 & 51.3 & 77 & 27.3 & 41 & 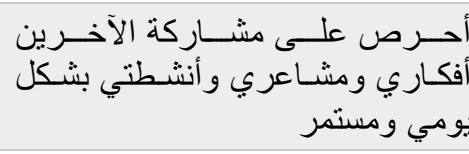 \\
\hline 44.7 & 67 & 36.7 & 55 & 18.7 & 28 & 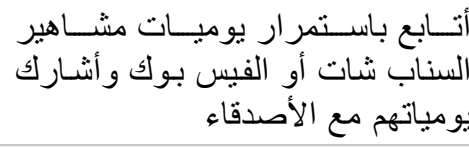 \\
\hline 29.3 & 44 & 37.3 & 56 & 33.3 & 50 & 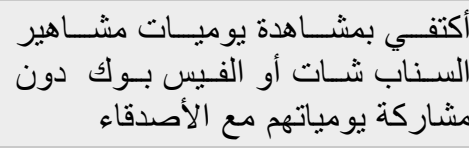 \\
\hline 32.0 & 48 & 45.3 & 68 & 22.7 & 34 & 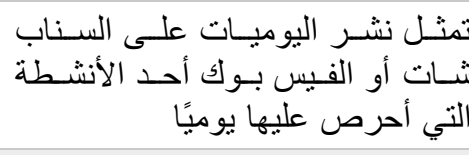 \\
\hline 14.7 & 22 & 50.0 & 75 & 35.3 & 53 & 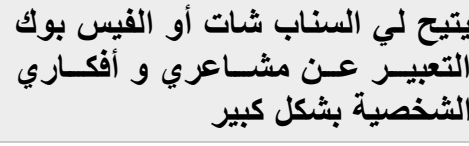 \\
\hline 18.7 & 28 & 17.3 & 26 & 64.0 & 96 & 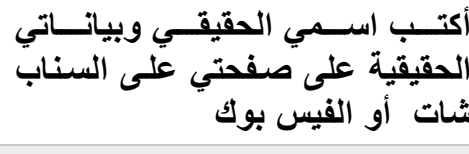 \\
\hline & & & & & 10. & 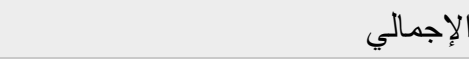 \\
\hline
\end{tabular}


توضح بيانات الجدول السابق الآتي: -

- أكدت نتائج الدراسة على حرص أفراد العينة على كتابـــة أســـائهم الحقيقيـــة

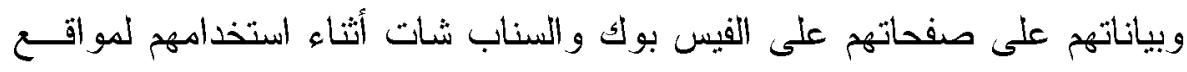

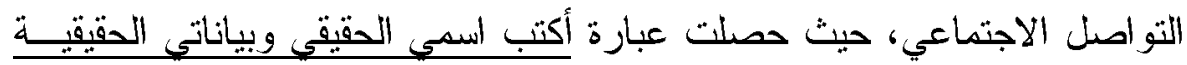

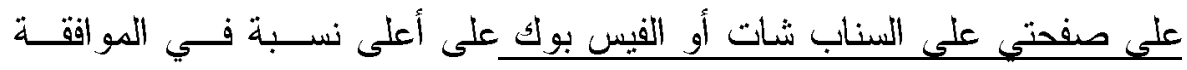
الثديدة والتي بلغت (ع \%) من إجمالي العينة.

- كما أكدت نتائج الدراسة على أن أفر اد العينة يجدوا أن مــوقعي الفـيس بــوك

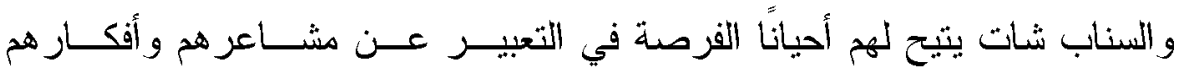
الثخصبة وذلك بنسبة (.0\%) بينما ترى نسبة (ب.0\%\%) من أفراد العينة أنهـا تتيحها لهم بشكل دائم وذلك في الإجابة على عبارة يتيح لي السناب شات أو الفيس يوك التعبير عن مشاعري و أفكاري النخصية بشكل كبير

- أوضحت نتائج الدراسة أيضًا مو اظبة نسبة من أفراد العينة في بعض الأحيــان

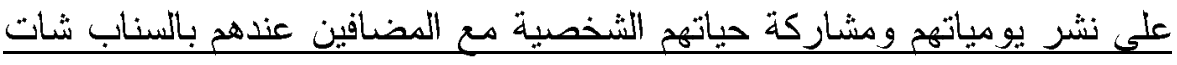

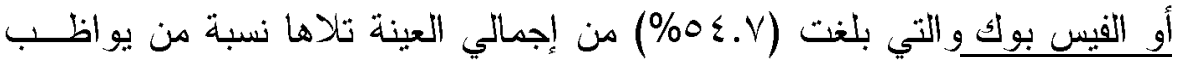

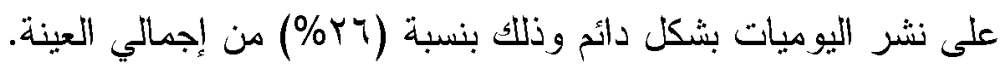
- أكدت ننائج الدراسة أيضًا على عدم المنابعة المستمرة ليوميات مشاهير السناب

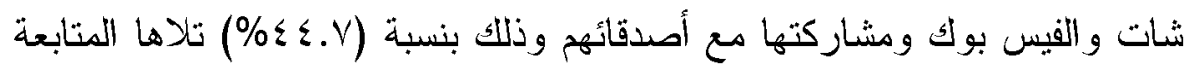

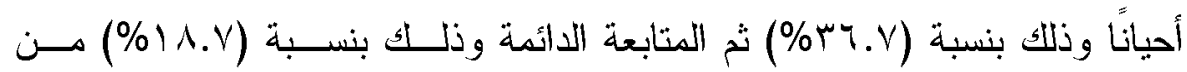

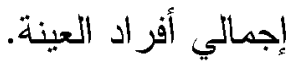

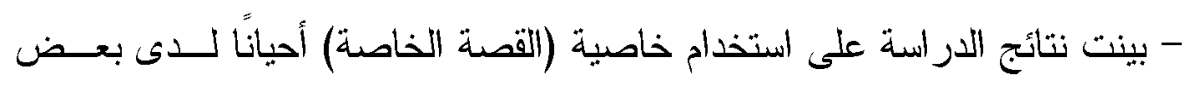

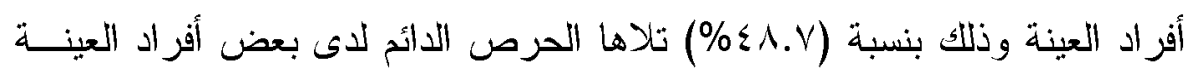


على خاصية القصة الخاصة وذلك بنسبة (Y.Y.Y\%)، تلاها عدم استخدام الخاصية

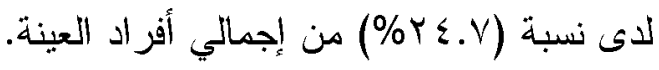

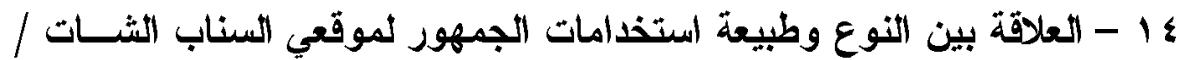
الفيس بوكك: وهو ما يوضحه الجدول الآتي:

$$
\text { جلول رقم (1T) }
$$

العلاقة بين النوع وطبيعة استخدامات الجمهور لموقعي السناب الثات / الفيس بوك رك

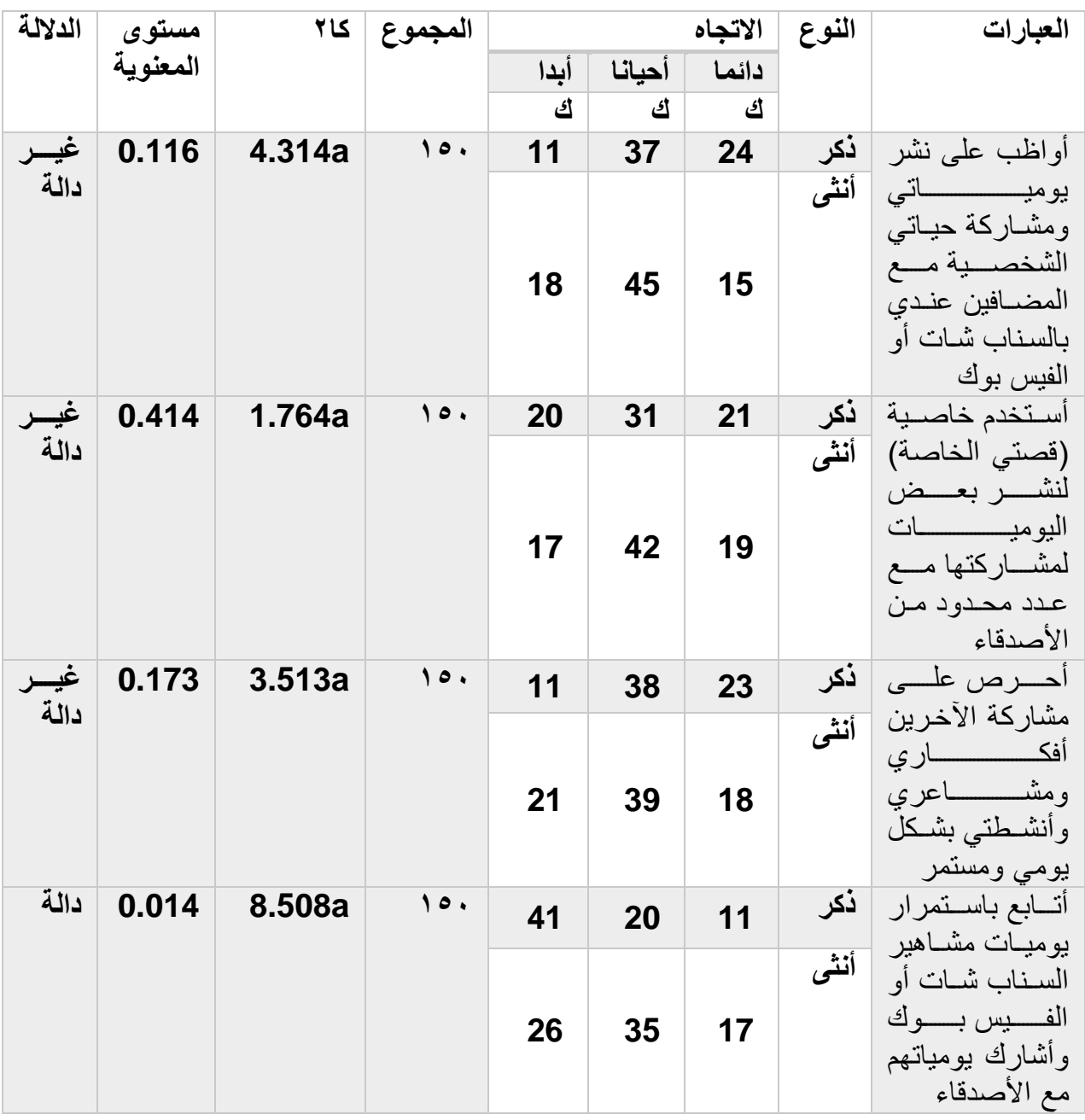




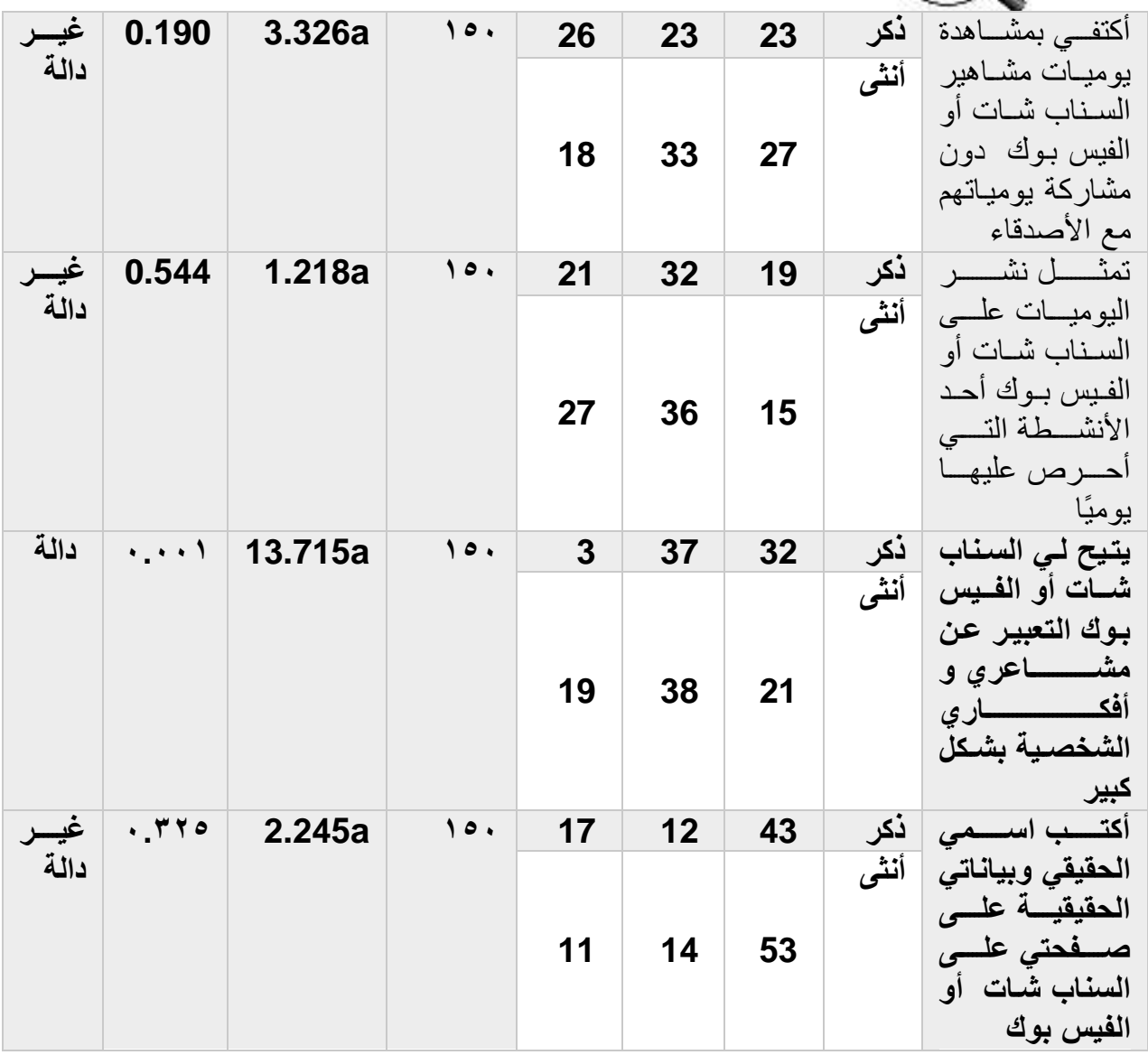

توضح بيانات الجدول السابق ما يلي: -

عدم وجود علاقة دالة إحصائياً بين نوع المبحوثين (ذكر -أنثى) وطبيعة اسـتخدامهم

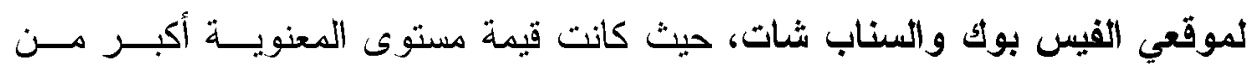
(0. . ) وهي قيمة غير دالة إحصائياً، باستثناء عبارتين وجد علاقة دالــة إحصــائية

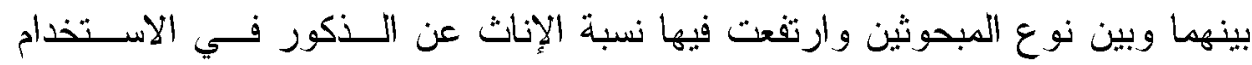

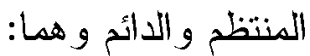


يتيح لي السناب شات أو الفيس بوك التعبير عن مشاعرب و أفكاري الشخصية بشـــكل

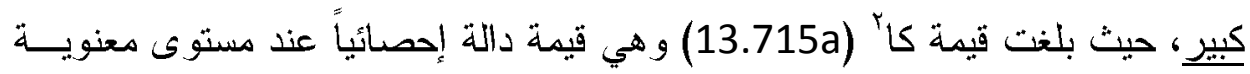

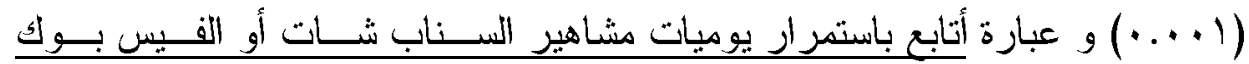

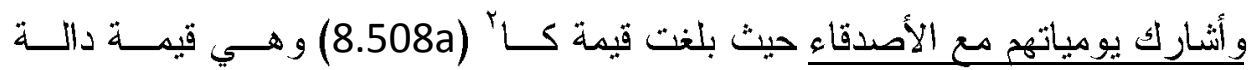

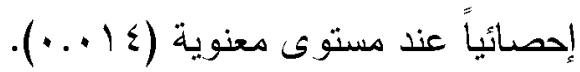

10 الفيس بوكك: وهو ما يوضحه الجدول الآتي: جدول رثم (1 أ)

اتجاهات الجمهور نحو أسباب انتهاك الخصوصية عبر موقعي السناب شات / الفيس بوك

\begin{tabular}{|c|c|c|}
\hline$\%$ & ك & أسباب انتهاك الخصوصية \\
\hline 9.3 & 14 & 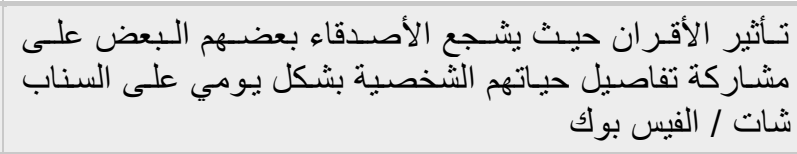 \\
\hline 12.7 & 19 & 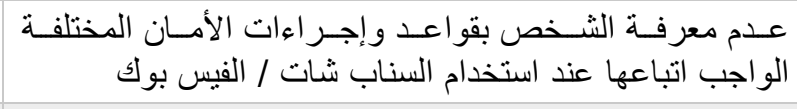 \\
\hline 2.7 & 4 & 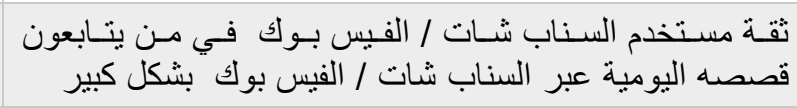 \\
\hline 8.7 & 13 & 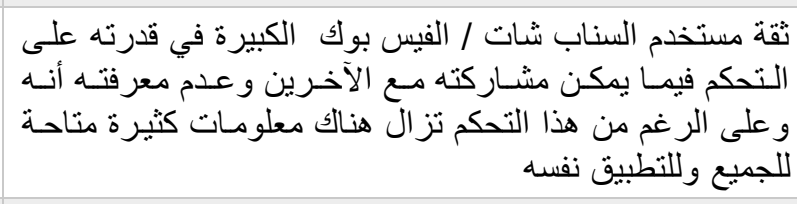 \\
\hline 3.3 & 5 & عدم حرص المستخدم على البيانات الثخصبة له أو لغيره \\
\hline - & $\cdot$ & بوك دور اف في انتهاك الخصوص المنشيةر عبر السناب شـات / الفيس \\
\hline 63.3 & 95 & كل ما سبق \\
\hline 0 & 0 & أخرى تذكر \\
\hline $1 \ldots$ & 10. & الإجمالي \\
\hline
\end{tabular}




\section{توضح بيانات الجدول السابث:}

ارتفاع إدر اك الجمهور بأسباب انتهاك الخصوصية عبر مــوقعي الفـيس بـــك و السناب شات حيث بلغت نسبة المبحوثين اللذين اختارو ا فئة (كل ماسبق) و التـي

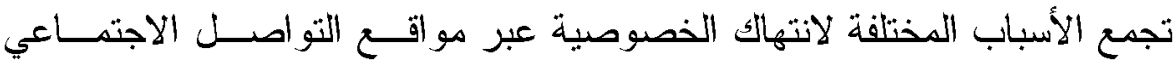

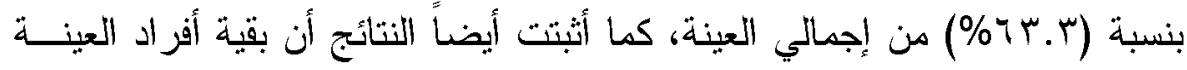

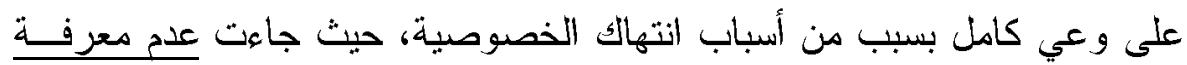

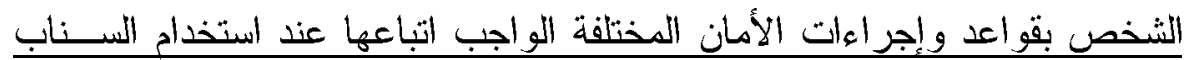
شات / الفيس بوك في المركز الثاني كسبب من أسباب انتهاك الخصوصية عبــر

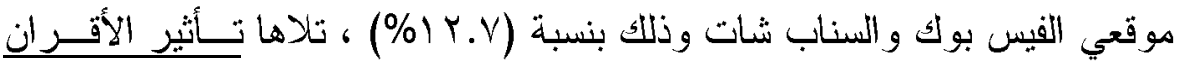
حيث يشجع الأصدقاء بعضه البعض على مشاركة تفاصبل حيـاتهم الشخصـية بشكل يومي على السناب شات / الفيس بوك وذلك بنسبة (ب.9\%) مـن إجمـالي

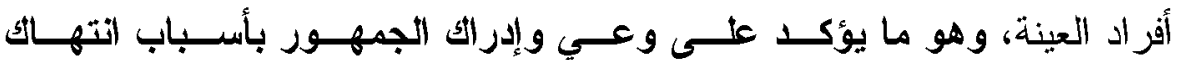
الخصوصية عبر مواقع التواصل الاجتماعي. 
17 - العلاقة بين الجنسية و اتجاهات الجمهور نحو أسباب اتتهـاكك الخصوصــية عبر موقعي السناب شات / الفيس بوك : وهو ما يوضحه الجدول الآتي :

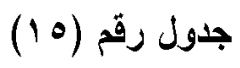

العلاقة بين الجنسية واتجاهات الجمهور نحو أسباب انتهاك الخصوصية عبر موقعي السناب شنات / الفيس بوك

\begin{tabular}{|c|c|c|c|}
\hline \multirow[t]{2}{*}{ 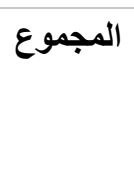 } & \multicolumn{2}{|c|}{ 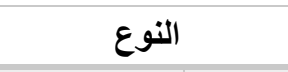 } & \multirow[t]{3}{*}{ أسباب النتهاك الخصوصية } \\
\hline & غير مصري & 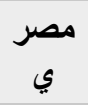 & \\
\hline ك & ك & ك & \\
\hline $1 \leq$ & 1. & $\varepsilon$ & 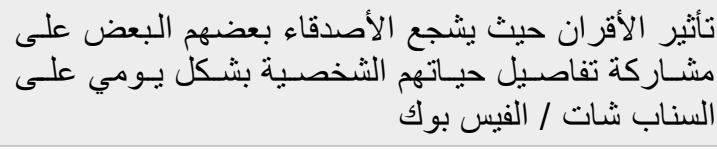 \\
\hline 19 & 1. & 9 & 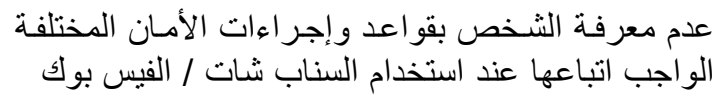 \\
\hline$\varepsilon$ & 1 & $r$ & 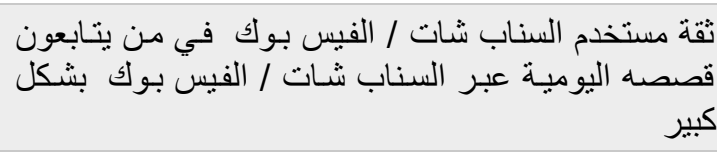 \\
\hline Ir & $\varepsilon$ & 9 & 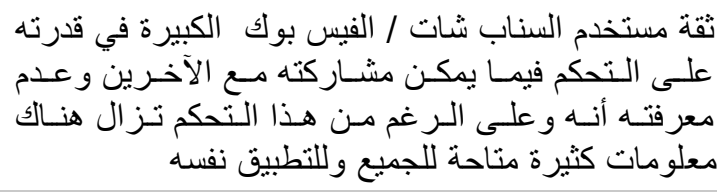 \\
\hline 0 & . & $\bullet$ & لغيرهم حـرص المســخدم على البيانـات الشخصـية لـه أو \\
\hline · & · & · & 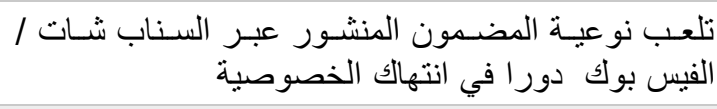 \\
\hline 90 & $\varepsilon 0$ & o. & كل ما سبق \\
\hline$\cdot$ & $\cdot$ & $\cdot$ & أخرى تذكر \\
\hline 10 & v. & $\Lambda$. & الإجمالي \\
\hline
\end{tabular}

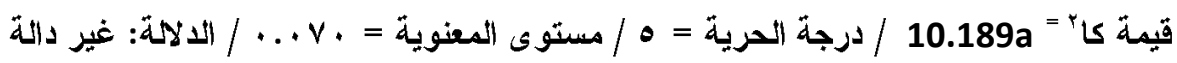




\section{توضح بيانات الجدول السابق ما يلي: -}

عدم وجود علاقة دالة إحصائياً بــين جنسـية المبحــوثين (مصــري-غيرمصــرب) و اتجاهاتهم نحو أسباب انتهاك الخصوصية عبر موقعي الفيس بوك و الســناب شــات،

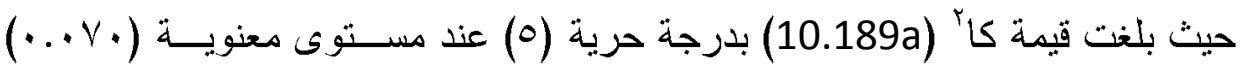
و هي قيمة أكبر من (0. . .) وهي قيمة غير دالة إحصائياً وهو ما يدل على عدم تأثير

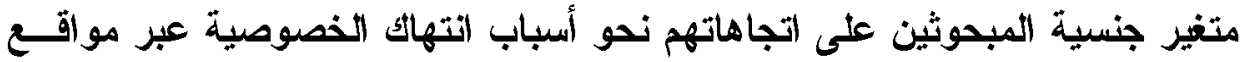

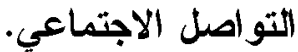
IV - اتجاهات الجمهور نحو المخاطر التي قد يتسبب فيها انتهاك الخصوصية عبـر موقعي السناب الثنات / الفيس بوكك: وهو ما يوضحه الجدول الآتي: جلول رثم (14)

اتجاهات الجمهور نحو المخاطر التي قد يتسبب فيها انتهاتك الخصوصية عبر موقعي السناب الثات / الفيس بوك

\begin{tabular}{|c|c|c|c|c|c|c|}
\hline \multicolumn{6}{|c|}{ الاتجاه } & \multirow[t]{3}{*}{ العبارة } \\
\hline \multicolumn{2}{|c|}{ معارض } & \multicolumn{2}{|c|}{ محايد } & \multicolumn{2}{|c|}{ مؤيد } & \\
\hline$\%$ & ك & $\%$ & ك & $\%$ & ك & \\
\hline 6.0 & 9 & 14.7 & 22 & 79.3 & 119 & 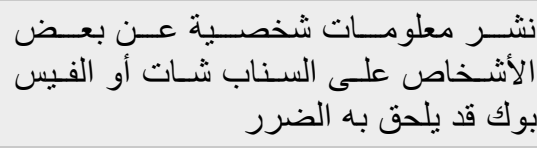 \\
\hline 8.7 & 13 & 8.7 & 13 & 82.7 & 124 & 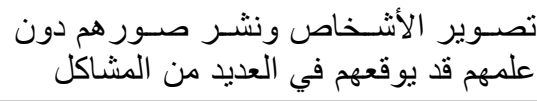 \\
\hline 2.7 & 4 & 17.3 & 26 & 80.0 & 120 & 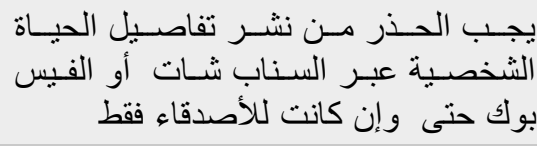 \\
\hline 10.7 & 16 & 23.3 & 35 & 66.0 & 99 & 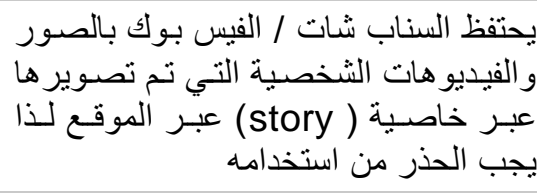 \\
\hline
\end{tabular}




\begin{tabular}{|c|c|c|c|c|c|c|}
\hline 7.3 & 11 & 19.3 & 29 & 73.3 & 110 & 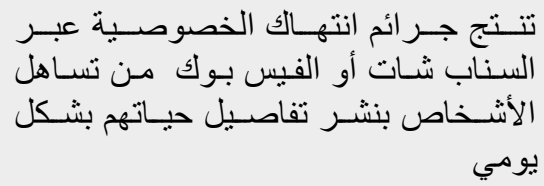 \\
\hline 5.3 & 8 & 26.0 & 39 & 68.7 & 103 & 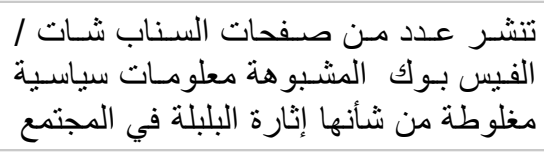 \\
\hline 6.7 & 10 & 18.7 & 28 & 74.7 & 112 & 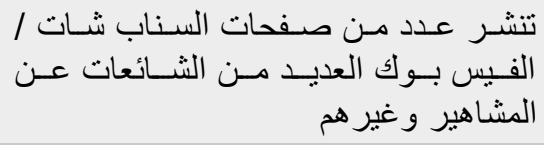 \\
\hline 9.3 & 14 & 26.0 & 39 & 64.7 & 97 & 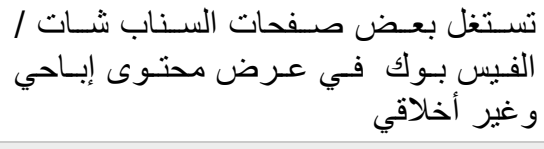 \\
\hline & & & & & 10. & الإجمالي \\
\hline
\end{tabular}

توضع بيانات الجدول السابق ما يلي: -

أكلات نتائج الدراسة على ارتفاع نسبة تأييد الجمهور للتبــارات التــي تعبـر عـن المخاطر التي يتسبب فيها انتهاك الخصوصية عبر موقعي القيس بوك والسناب شات واتجاهاتهم نحوها، حبث جاءت نسبة تأيبد الجمهور لعبارة تصوير الأشخاص ونشـر صور هم دون علمهم قد يوقعهم في العديد من المشاكل في مقدمة العبار ات التي تمثـل

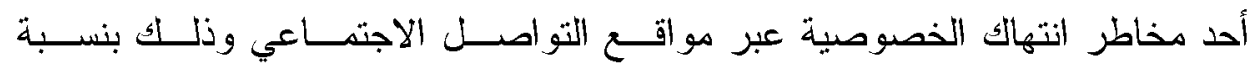
(\% \%.V.V)

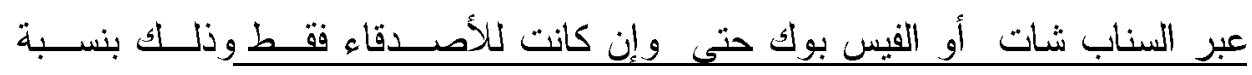

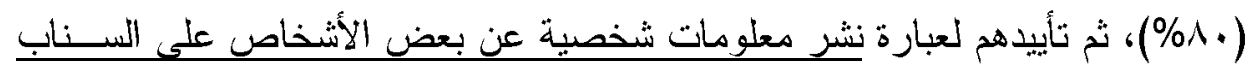

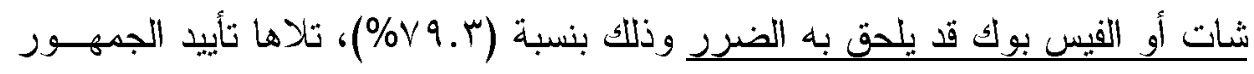
لعبارة تنشر عدد من صفحات السناب شات / الفيس بوك العديد من الثــائعات عـن

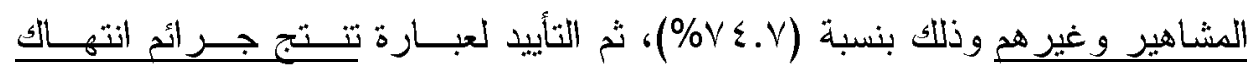
الخصوصية عبر السناب شـات أو الفيس بوك من تساهل الأشخاص بنشــر تفاصــيل 
حياتهم بشكل يومي وذلك بنسبة (r.r\%)، بينما جاءت عبارة تستغل بعض صفحات

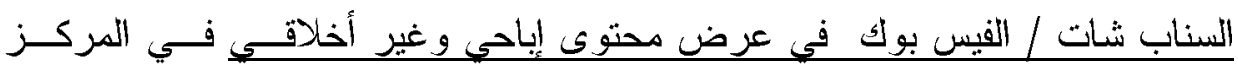
الأخير من بين العبازات التي يؤيدها أفراد العينة ويعتبر ها أحد المخاطر التي تتســبب

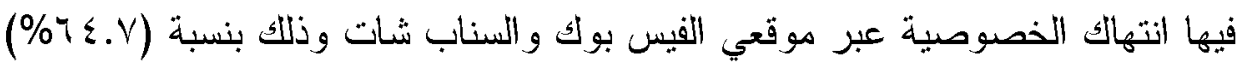

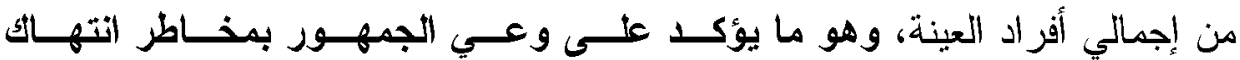
الخصوصية عبر مواقع التواصل الاجتماعي. لرن

11 - اتجاهات الجمهور نحو موقعي السناب الثثات / الفيس بوك : وهو ما يوضحه

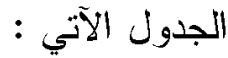

$$
\text { جذول رثم (iv) }
$$

اتجاهات الجمهور نحو موقعي السناب الشات / الفيس بوك رك

\begin{tabular}{|c|c|c|c|c|c|c|c|c|c|c|}
\hline \multicolumn{10}{|c|}{ الاتجاه } & العبارة \\
\hline \multicolumn{2}{|c|}{ بشدة } & \multicolumn{2}{|c|}{ معارض } & \multicolumn{2}{|c|}{ محايد } & \multicolumn{2}{|c|}{ مو افق } & \multicolumn{2}{|c|}{ مو افق بشدة } & \\
\hline$\%$ & ك & $\%$ & ك & $\%$ & ك & $\%$ & ك5 & $\%$ & ك5 & \\
\hline 2.7 & 4 & 12.7 & 19 & 32.7 & 49 & 26.7 & 40 & 25.3 & 38 & 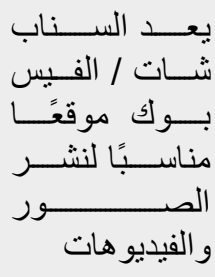 \\
\hline 2.0 & 3 & 12.7 & 19 & 23.3 & 35 & 40.0 & 60 & 22.0 & 33 & 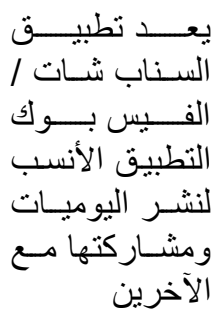 \\
\hline 6.7 & 10 & 16.7 & 25 & 38.0 & 57 & 24.0 & 36 & 14.7 & 22 & لا أجـــ خطـورة \\
\hline
\end{tabular}




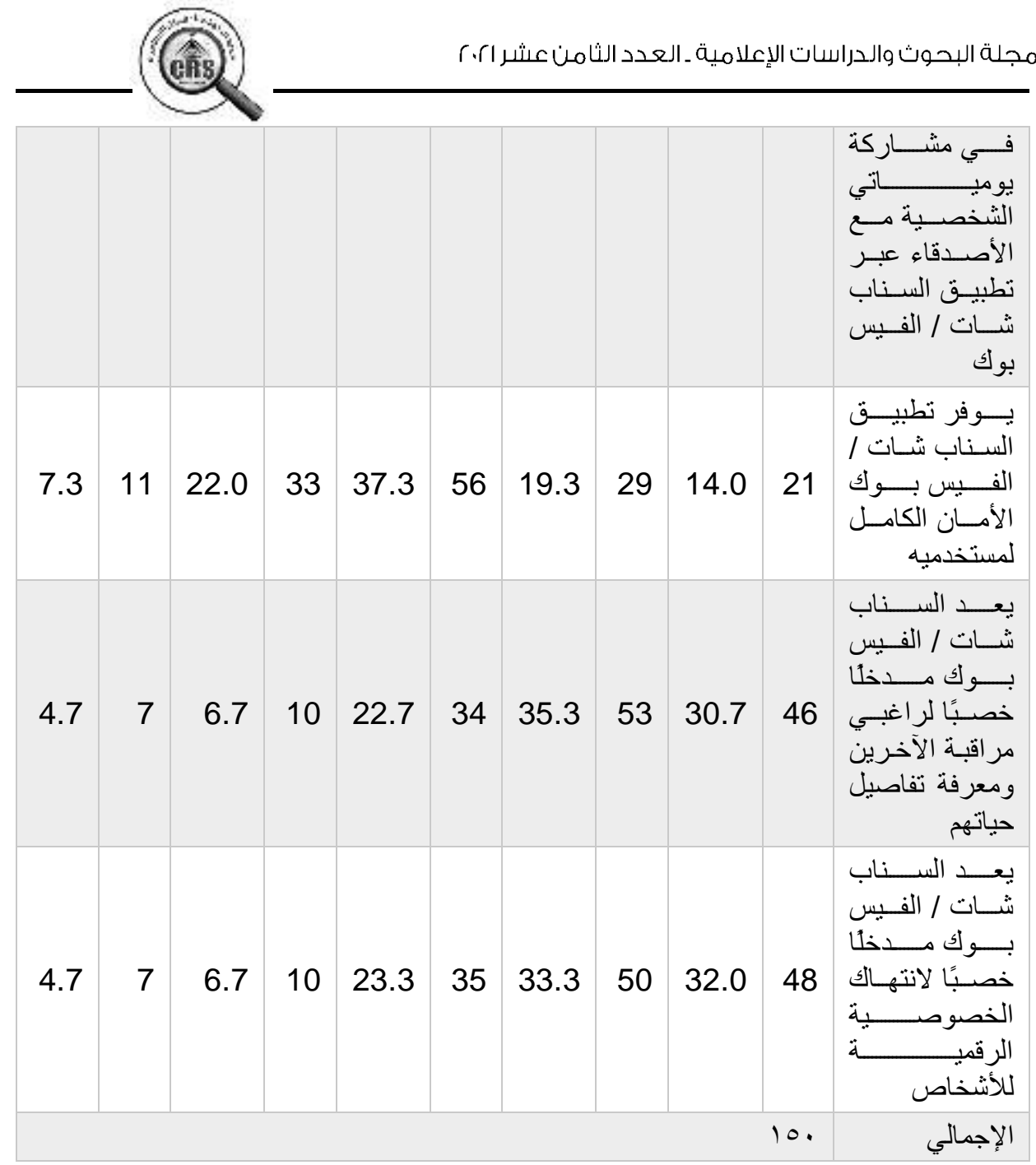

توضح بيانات الجدول السابق ما يلي: أكلات نتائج الدراسة على تفوق الاتجاهات الإيجابية للجمهور نحو مــوقعي العــناب شات والفيس بوك وذلك على النحو الآتي:

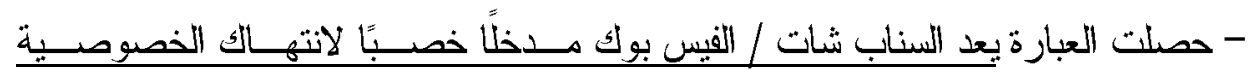

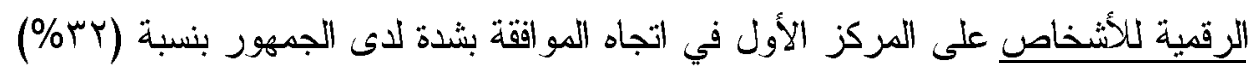

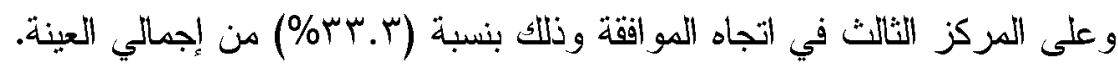
or 


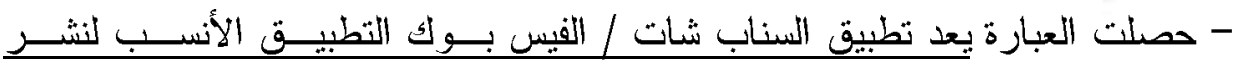

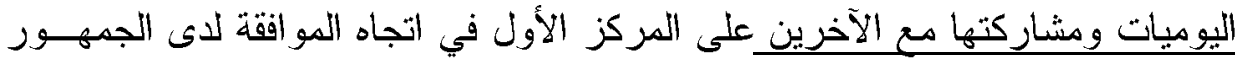

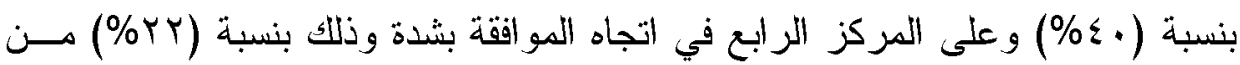

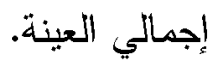

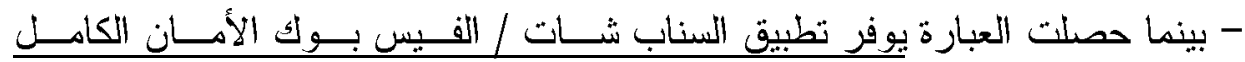

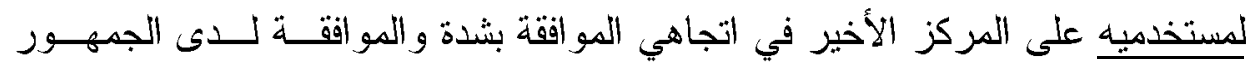

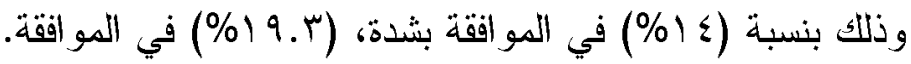

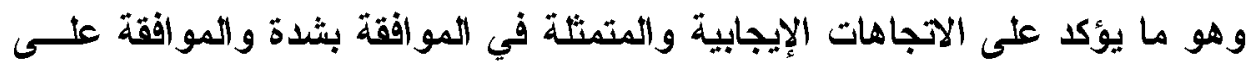

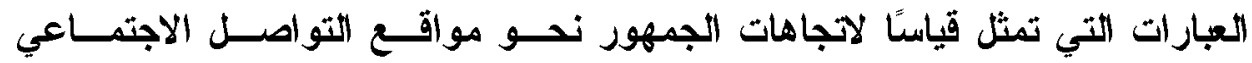
والمتمثلة في السناب شات و الفيس بوثك.

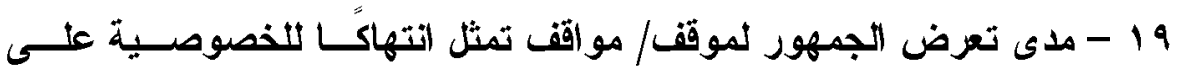
السناب شات / الفيس بوك: و هو ما يوضحه الثنكل الآتي:

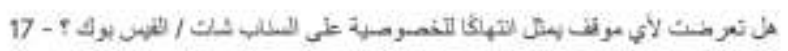
150 responses

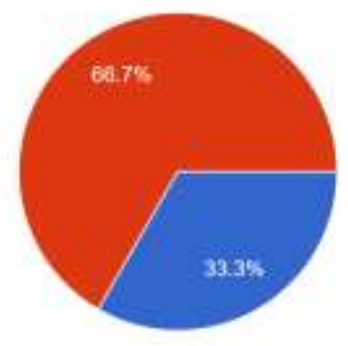

(9) - (9كل رقم

مدى تعرض المبحرثين لموقف يمثل انتهاك للخصوصية عبر هوقعي السناب شات/ الفيس بوك 


\section{توضح بيانات الثكل السابق: - ت}

تعرض نسبة قليلة من أفراد العينة لموقف من مواقف انتهاكات الخصوصية على موقعي السناب شات و الفيس بوك وذلك بنسبة (r.rr\%) من إجمالي العينة. • r - الموقف/المواقف التي تعرض فيها الجمهور لاتتهاك الخصوصية عير مــوقعي السناب شات / الفيس بوكك: وهو ما يوضحه الجدول الآتي:

$$
\text { جدول رقم (11) - (11) }
$$

الموقف/المواقف التي تعرض فيها الجمهور لاتتهائ الخصوصية عبر موقعي السناب شات / الفيس بورك الانت

\begin{tabular}{|c|c|c|}
\hline$\%$ & ك & 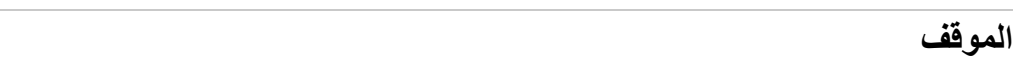 \\
\hline$\varepsilon$ & r & 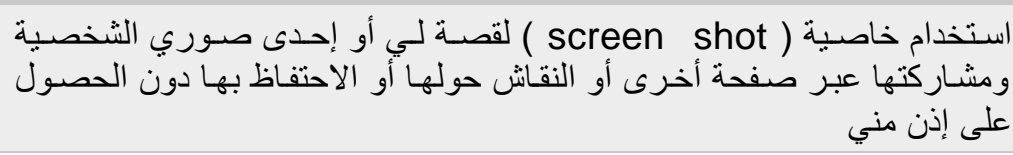 \\
\hline 17 & $\wedge$ & إضافة إلى مجمو عات خاصة على السناب / الفيس بوك دون أخذ الإذن مني \\
\hline 1. & $\bullet$ & التو اصل من قبل أشخاص غير مرحب بهم عبر خاصة الدردشة ( chat ) \\
\hline rr & 11 & 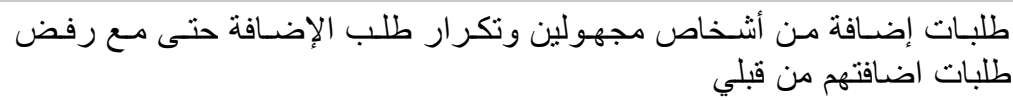 \\
\hline$\varepsilon$ & r & محاولة سرقة حسابي م \\
\hline 1. & $\bullet$ & تلقي طلبات إضافة من أشخاص وهميين \\
\hline Ar & $\varepsilon 1$ & كل ما سبق \\
\hline 7 & r & أخرى تذكر \\
\hline $1 \ldots$ & ๑. & الإجمالي \\
\hline
\end{tabular}

* الإجمالي هنا من عدد اللذنين أجابو ابــ (نعم) نتعرضهم لموقف انتهاك خصوصبة 


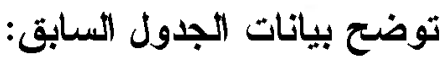

أن أكثر أفراد العينة ممن أجابو ابنعم لتعرضهم لمو اقف انتهاكات الخصوصـية عبــر

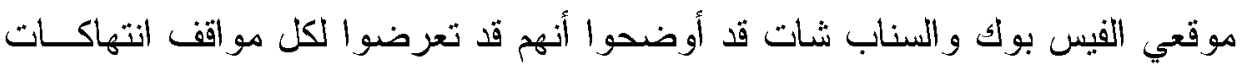

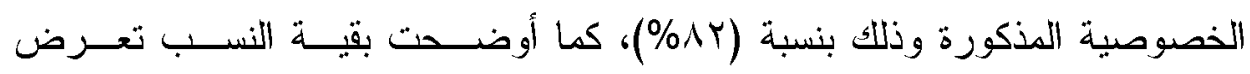
المبحوثين لموقف من مواقف انتهاك الخصوصبة، بينما عبر (T\%) من إجمالي العينة

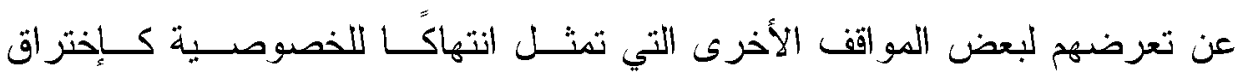

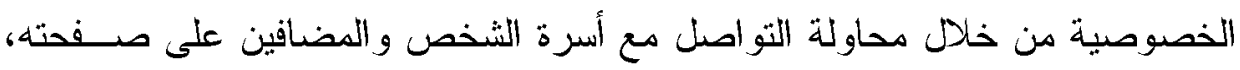

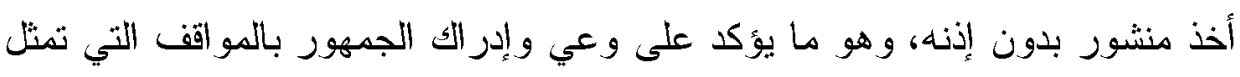

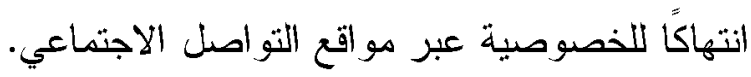
|ب - رد فعل الجمهور تجاه مواقف انتهائ الخصوصية عبر موقعي السناب شات / الفيس بوك: وهو ما يوضحه الجدول الآتي:

$$
\text { جدول رقم (19) }
$$

رد فعل الجمهور تجاه مواقت انتهاك الخصوصية عبر موقعي السناب شات / الفيس بوك

\begin{tabular}{|c|c|c|}
\hline$\%$ & ك & رد الفعل \\
\hline 10.7 & 16 & رفض طلبات الصداقة الغير مرغوب فيها \\
\hline 7.3 & 11 & إلغاء صداقة وحظر الأصدقاء الوهييين من حسابي بشكل نهائي \\
\hline 4.7 & 7 & 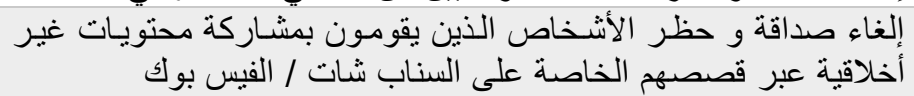 \\
\hline 4.7 & 7 & إلظــاء منابعة الصفحات التي تقدم موضو عات غير مناسبة من وجهـة \\
\hline 1.3 & 2 & 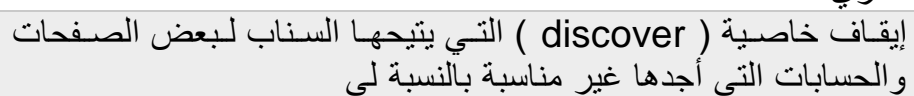 \\
\hline 2.0 & 3 & تحذير أصدقائي من الأشخاص و الصفحات التّي تنتهك الخصوصية \\
\hline 68.7 & 103 & 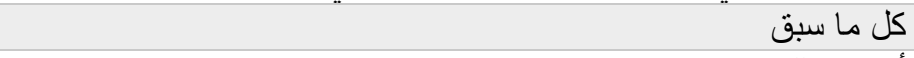 \\
\hline .7 & 1 & أخرى تذكر \\
\hline 1.. & 10 . & الإجمالي \\
\hline
\end{tabular}




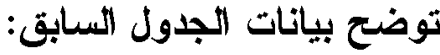

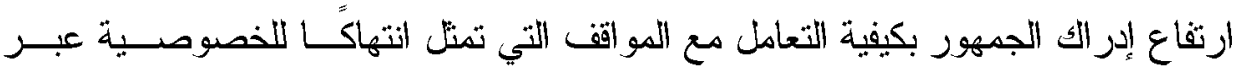

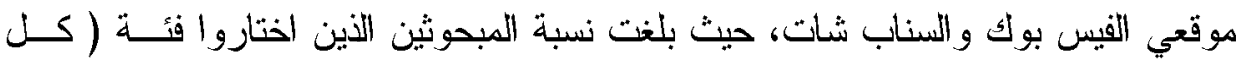

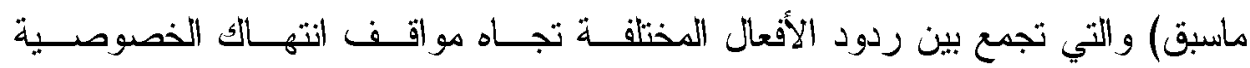
(\%个A.V)

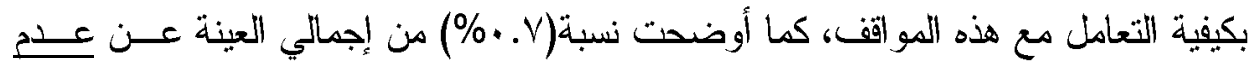

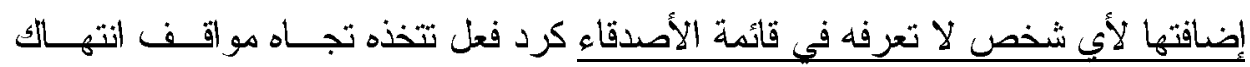

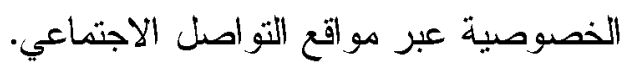

Y Y - اتجاهات الجمهور نحو أسباب استمرار انتهـاكت الخصوصـية عبـر مــوقعي السناب شات / الفيس بوك: وهو ما يوضحه الجدول الآتي :

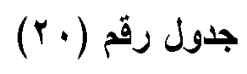

اتجاهات الجمهور نحو أسباب استمرار انتهاكك الخصوصية عبر موقعي السناب شات / الفيس بوك الفي

\begin{tabular}{|c|c|c|}
\hline$\%$ & ك & الأسباب \\
\hline 5.3 & 8 & 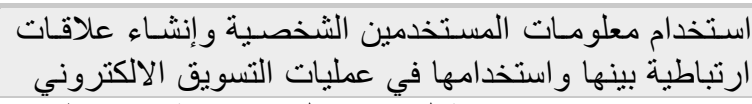 \\
\hline 14.0 & 21 & السناب شود قو / الفيس رادعة لمنتهكي الخصوصية عبر تطبيق \\
\hline 4.7 & 7 & 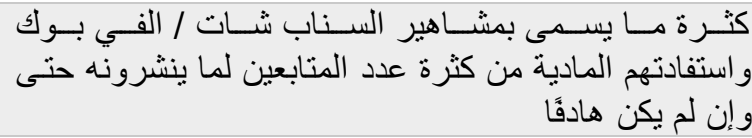 \\
\hline 6.7 & 10 & 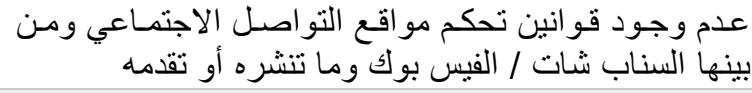 \\
\hline 4.0 & 6 & 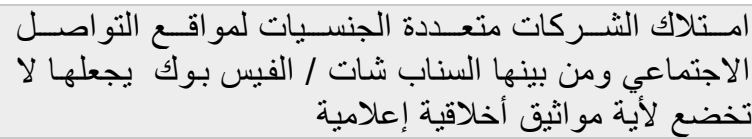 \\
\hline 65.3 & 98 & كل ما سبق \\
\hline $1 \ldots$ & 10. & الإجمالي \\
\hline
\end{tabular}




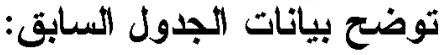

بينت نتائج الدراسة وعي الجمهور بأسباب استمر ار انتهاك الخصوصية عبر موقعي الفيس

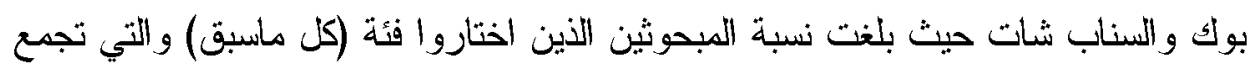

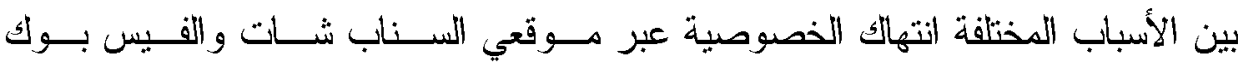

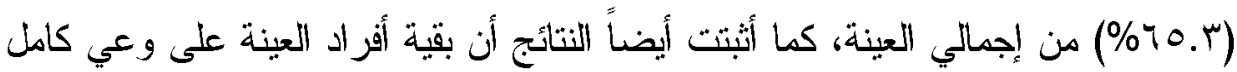
بسبب من أسباب استمرار انتهاك الخصوصبة عبر مواقع التواصل الاجتماعي.

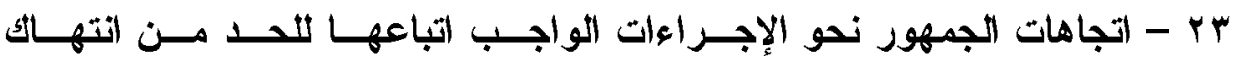
الخصوصية عبر موقعي السناب شات / الفيس بوك : و هو ما يوضحه الجدول الآتي: جدول رقم (r)

اتجاهات الجمهور نحو الإجراءات الواجب اتباعها للحد من انتهاك الخصوصية عبر موقعي

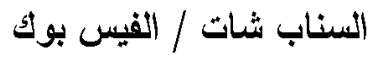

\begin{tabular}{|c|c|c|}
\hline$\%$ & ك5 & الإجراءات \\
\hline 8.7 & 13 & 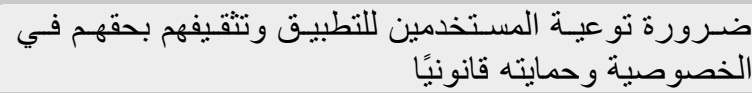 \\
\hline 7.3 & 11 & 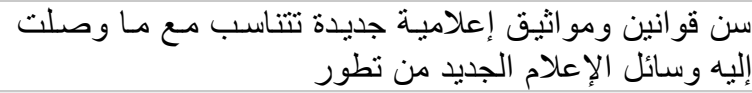 \\
\hline 3.3 & 5 & 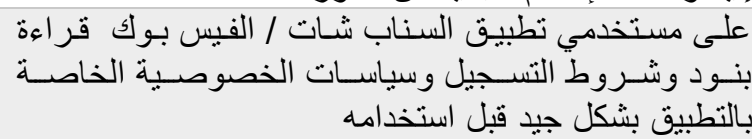 \\
\hline 2.0 & 3 & 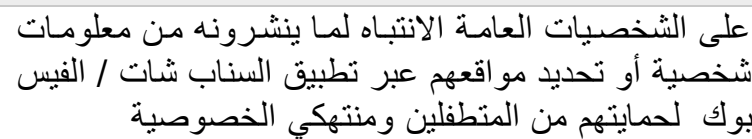 \\
\hline 3.3 & 5 & 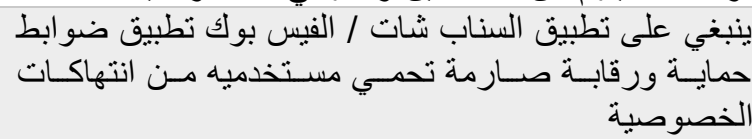 \\
\hline 4.7 & 7 & 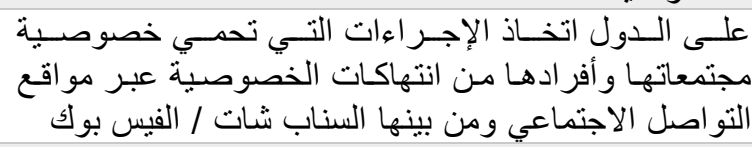 \\
\hline 70.7 & 106 & كل ما سبق " \\
\hline $1 \ldots$ & 10. & الإجمالي \\
\hline
\end{tabular}


توضع بيانات الجدول السابق:

بينت نتائج الدر اسة وعي الجمهور بالإجر اءات الواجب اتباعهــا للحــــــن انتهــالك الخصوصية عبر موقعي الفيس بوك و السناب شات حيث بلغت نسبة المبحوثين الــذين

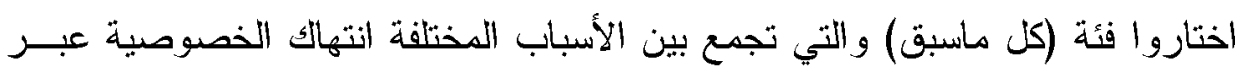

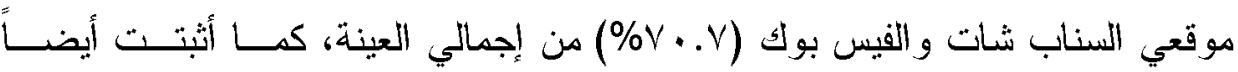

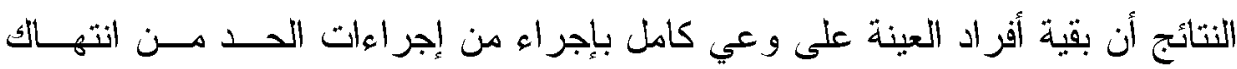
الخصوصية عبر مواقع التواصل الاجتماعي. ؟ Y - لمعرفة الفروق بين الجنسيات المختلفة للمبحوثين واتجاهاتهم نحسـو انتهــاك One Way الخصوصية عبر تطبيقي السناب شات / الفيس بؤك تم إجراء اختبـار Anova

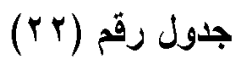

\section{One Way Anova اختبار}

لمعنوية الفروق بين الجنسيات المختلفة للبحوثين واتجاهاتهم نحو انتهائ الخصوصية عبر

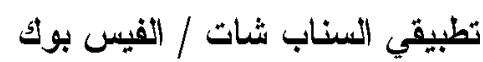

\begin{tabular}{|c|c|c|c|c|c|c|c|c|}
\hline \multirow{2}{*}{ المعنويةتِ } & \multirow{2}{*}{ 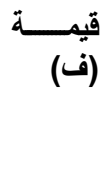 } & \multicolumn{2}{|c|}{ درجات الحرية } & \multirow{2}{*}{ الالمعيـــــراف } & \multirow{2}{*}{ المستوسبـ } & \multirow[t]{2}{*}{ العدد } & \multirow[t]{2}{*}{ الجنسية } & \multirow[t]{2}{*}{ المتغير } \\
\hline & & 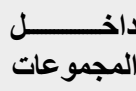 & المجموعات & & & & & \\
\hline \multirow[t]{2}{*}{.971} & \multirow[t]{2}{*}{.111} & \multirow[t]{2}{*}{$1 \leqslant 1$} & \multirow[t]{2}{*}{1} & $r . r \cdot V \cdot I$ & ๑.V... & $\Lambda$. & مصري & \multirow[b]{2}{*}{ 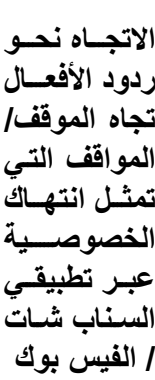 } \\
\hline & & & & r.rirv. & $0.0 \leqslant r q$ & 70 & غضيريـر & \\
\hline
\end{tabular}




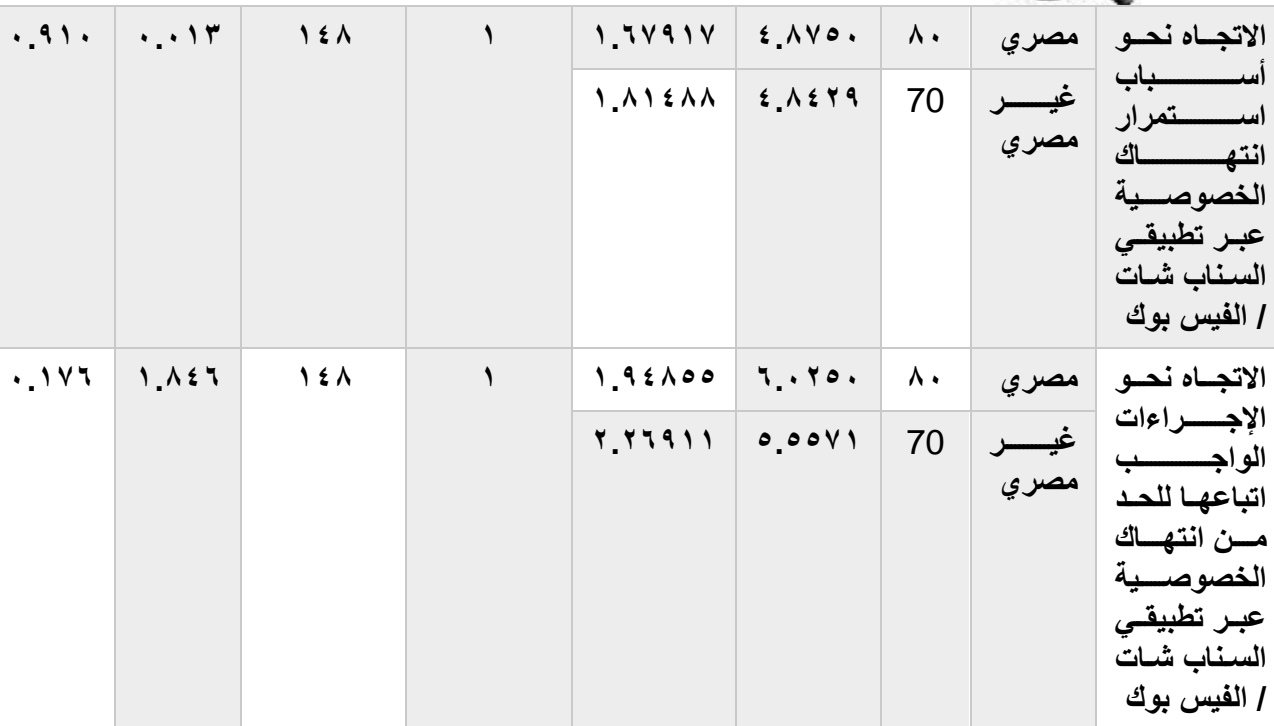

يتضح من بيانات الجدول السابق:

الاتجاه نحو ردود الأفعال تجاه الموقف/ المواقف التي تمثل انتهاك الخصوصبة عبـر

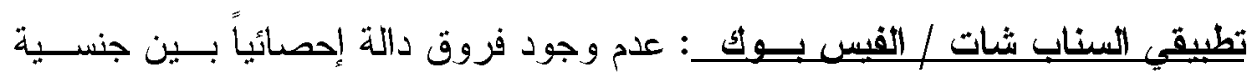

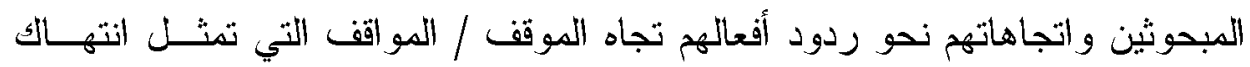

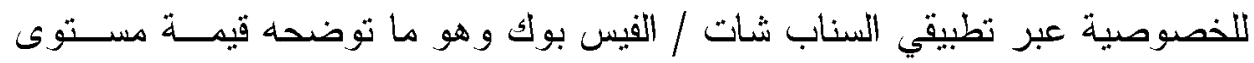

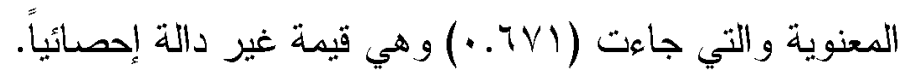

الاتجاه نحو أسباب استمر ار انتهايك الخصوصبة عبر تطبيقي السناب شات / الفـيس

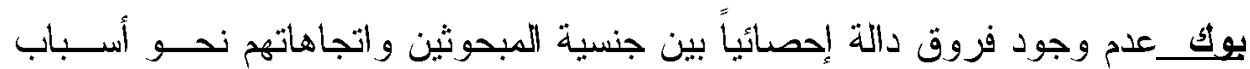

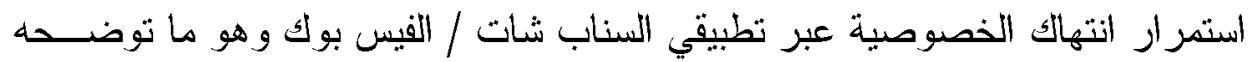
قيمة مستوى المعنوية والتي جاءت ( •9 . . ) وهي قيمة غير دالة إحصائيًا. الاتجاه نحو الإجر اءعات الواجب اتباعها للحد من انتهاتك الخصوصبة عبـر تطبية

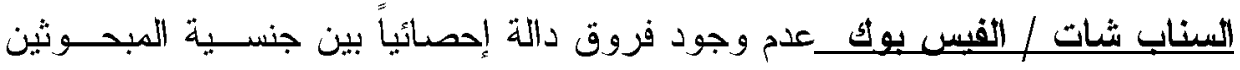


و اتجاهاتهم نحو الإجر اءات الو اجب اتباعها للحد من انتهاك الخصوصية عبر تطبيةـي

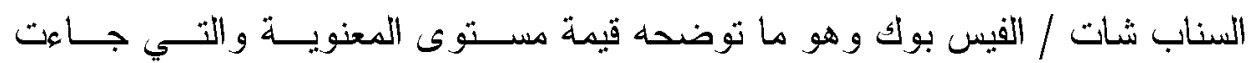

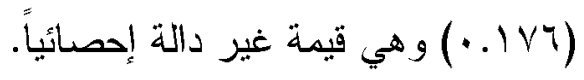

\section{ملخص النتائج:}

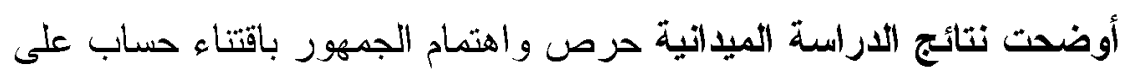

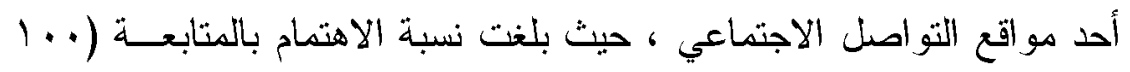

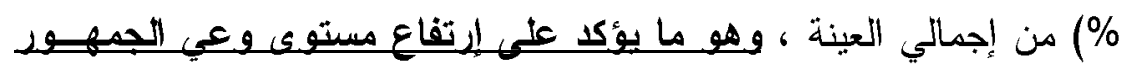

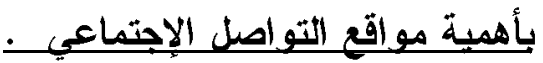

أوضحت نتائج الاراسة عدم وجود علاقــة دالــة إحصـائياً بـين جنسـية

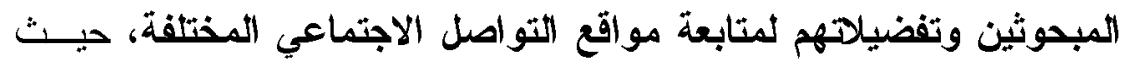

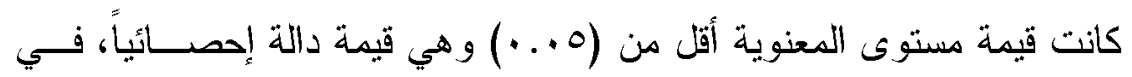

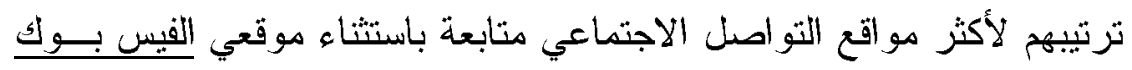

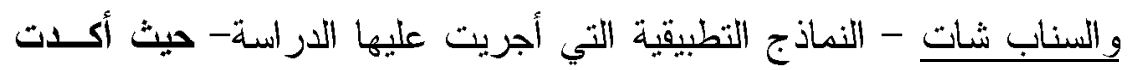

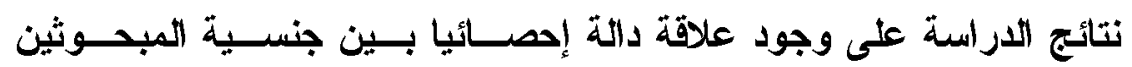

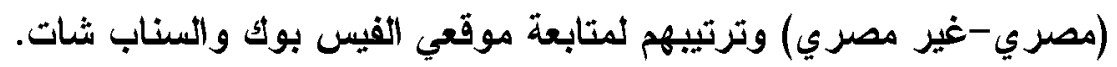
فبالنسبة لعينة المصريسن : جاء موقع الفيس بوك في الترتيبي الأول و الثاني ، فــي

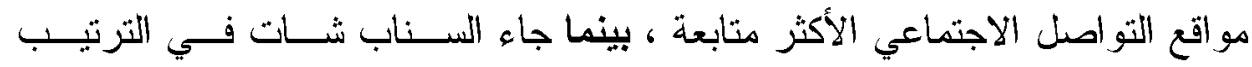
السادس لاى أفر اد عينة المصريين في المتابعة.

أميا عن عينة غير المصرين: فقد جاء موقع السناب شات في الترتيبي الأول والثاني،

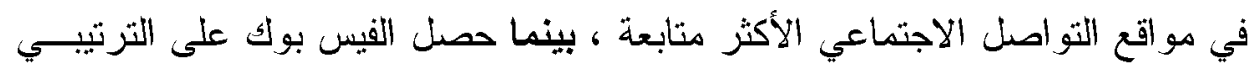
الأول و السادس لدى أفر اد عينة غير المصريين في المتابعة. 
وهو ما يتفق مع نتائج الارسات سابقة حيث أكلت دراسية (عبد النبي الطيب، فاطمة

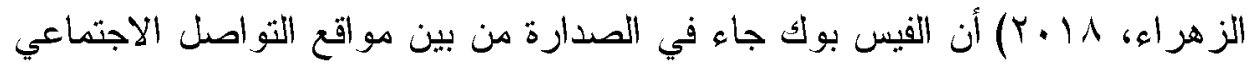
الأكثر استخداما بين أفر اد العينة، وذلك بنسبة (0ب\%) من أفراد العينة. كما أكلت دراسة (مركز القرار للار اسات الإعلامية، . r. . أنه وفق شركة الأبحاث

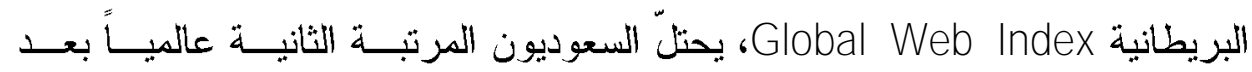

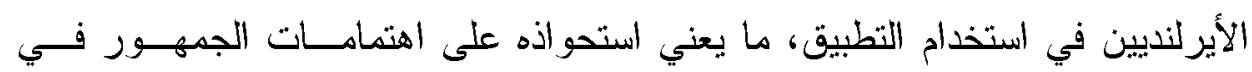

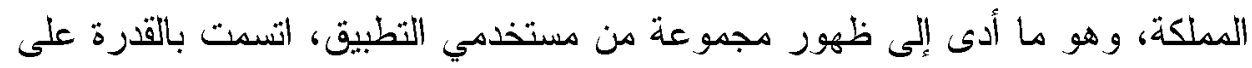

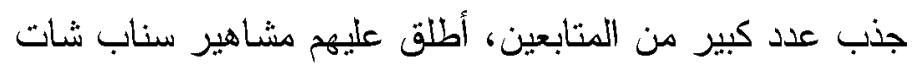

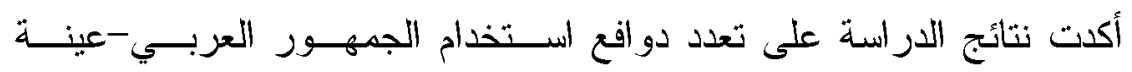

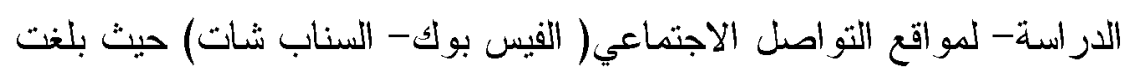

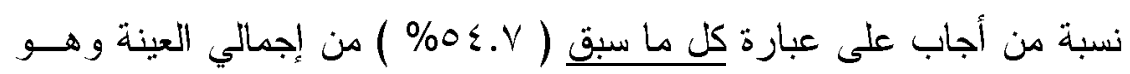

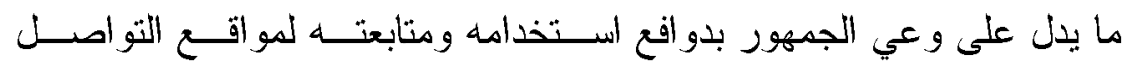

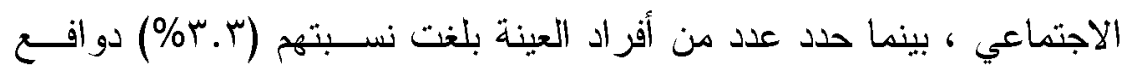

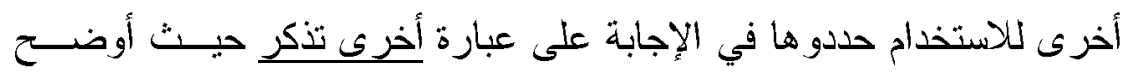

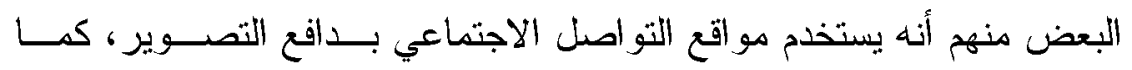

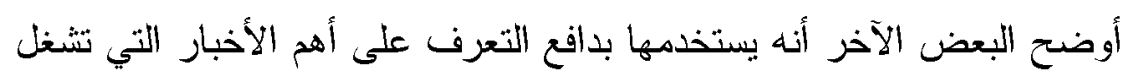
الناس، والبعض الآخر يستخدمها بدافع البحث عن فرص شر برائية معينة. عدم وجود علاقة دالة إحصائياً بين نوع المبحــوثين ودوافـــع اســتخدامهم

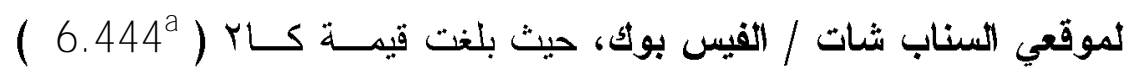

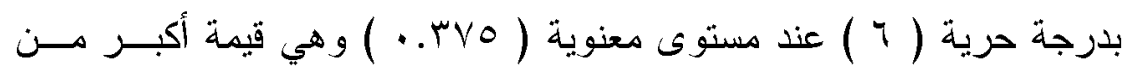

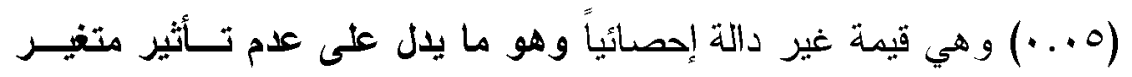
النوع على دوافع الاستخدام لمواقع التواصل الاجتماعي لادى أقراد العينة. 
حرص الجمهور على متابعة موقعي الفيس بوك و السناب شات بشكل يـومي حيث بلغت نسبة أفراد العينة الحريصين على متابعة مستجدات كورونا بشكل

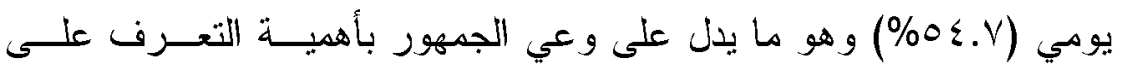

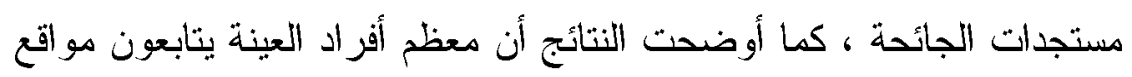
التواصل الاجتماعي أقل من ساعة وذلك بنسبة ( r.V.V \% ) مـن إجهـالي العينة، وهو ما يتو افق مع استمرارية المتابعة اليومية . أوضحت نتائج الدراسة أن أعلى نسبة كانت إضافة (أكثر من . .. صــديق)

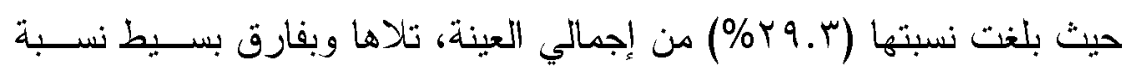

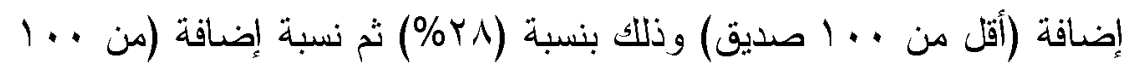

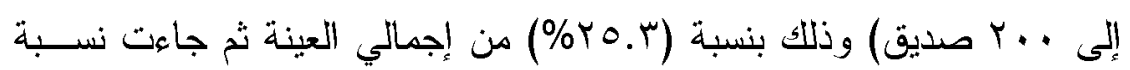

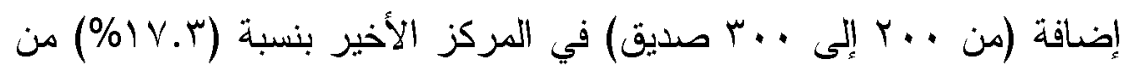

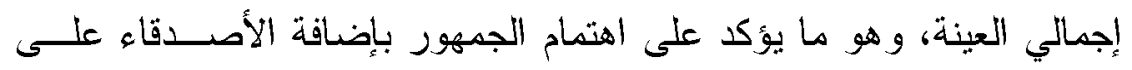
حساباتهج.

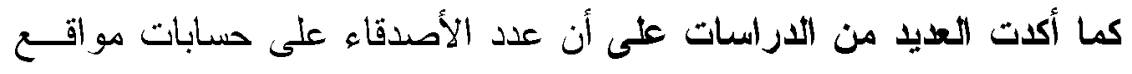
التو اصل الاجتماعي يعد مؤشرًا على كثافة الاستخدام لهذه المو اقع من ناحية،

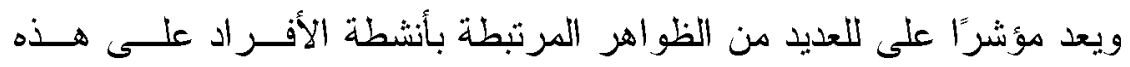

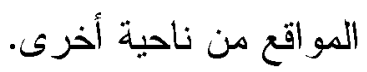
بينت نتائج الدراسة أن أكثر الأنشطة التي يقوم بها أفراد العينة على الســاب شات و الفيس بوك هي نشر العديد من القصص و المعلومات المتخصصة فـي مجال معين حيث بلغت نسبتها (

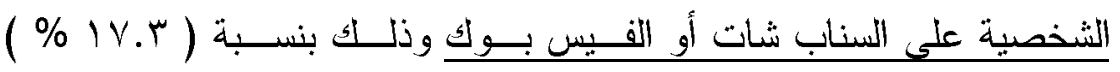

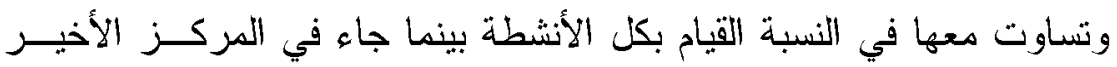


القيام بمجموعة أنشطة أخرى كالتصوير، الحصول على بعـض المعلومـات

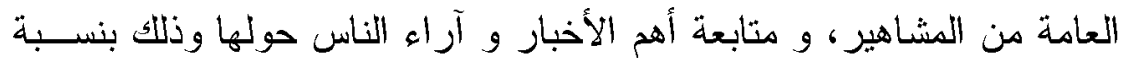
(r\%) من إجمالي أفراد العينة، وهو ما يدل على وعي الجمهور بما يقوم بـ البه من أنشطة أنثاء استخدامه لموقعي الفيس بوك الك و السناب شات.

وجود علاقة دالة إحصائياً بين نوع المبحوثين والأثشطة التي يقومسـوا بهـــا على موقعي السناب شات / الفيس بوكك، حيث بلغت قيمة كاب ( 14.571a

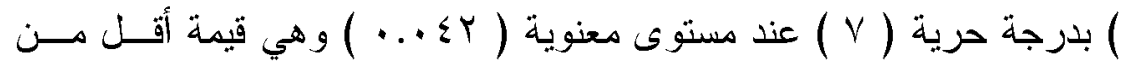

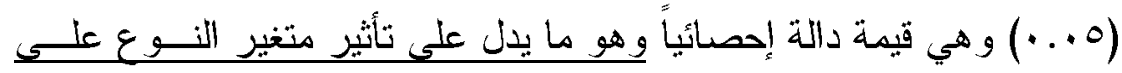
نوعية الأنشطة التي يقوم بها أفراد العينة أثناء استخدامهر لموقهي الفيس بوك و السناب شات.

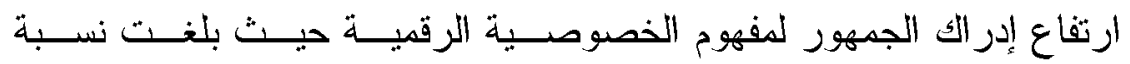
المبحوثين اللذين اختاروا فئة (كل ما سبق) والتي تجمع بين المفاهيم المختلفة للخصوصية الرقمية (.or.or\%) من إجمالي العينة بينما بلغت نسـبة أفــراد العينة الذين أجابو ا بعدم معرفتهم بدفهوم الخصوصية الرقمية نسـبة ضــئيلة

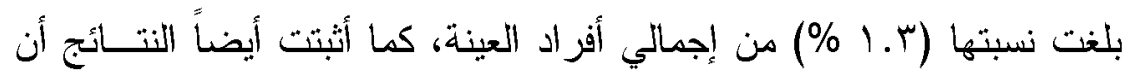

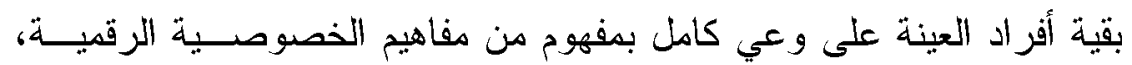
و هو ما يؤكد على وعي وإدر الك الجمهور لمفهوم الخصوصية الرقمية. ارتفاع إدر الك الجمهور لصور انتهالك الخصوصية الرقمية حبث بلغت نسـبة

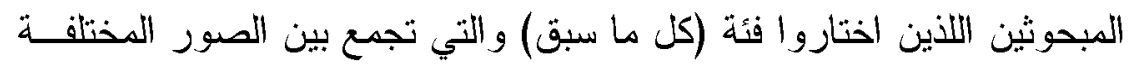

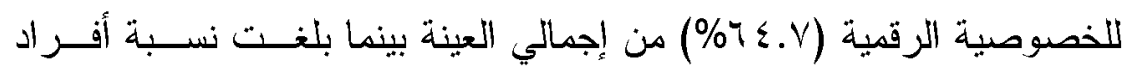

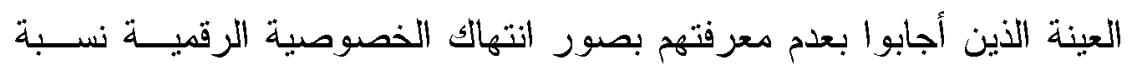

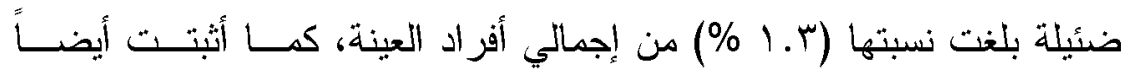


النتائج أن بقية أفراد العينة على وعي كامل بصــورة مــن صــور انتهـاك

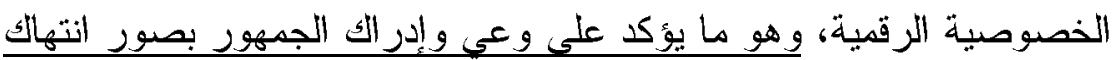
الخصوصية الرقمية.

تفوق الاتجاهات الإيجابية للجمهور في التعامل مع إعدادات الأمان الخاصــة بموقعي الفيس بوك والسناب شات، حيث حصلت عبارة أحرص على التحكر بشكل جيد في إعدادات الأمان الخاصة بي على السناب شات أو الفيس بــــك

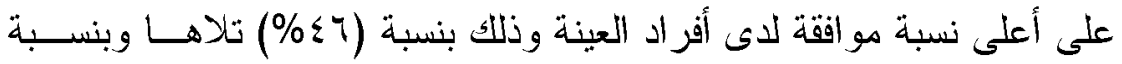

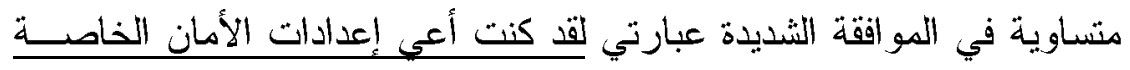

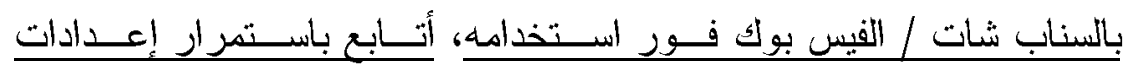

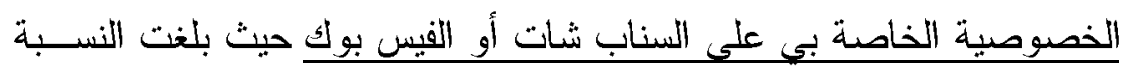

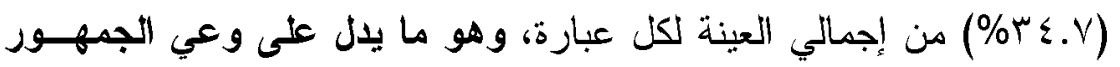

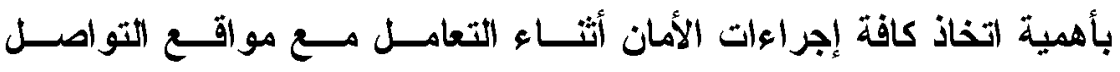
الاجتماعي. أكدت نتائج الدراسة على أن النسبة الأعلى لمــدى تعـرض أفــراد العينــة

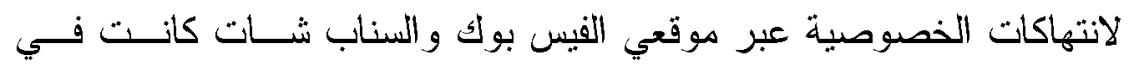

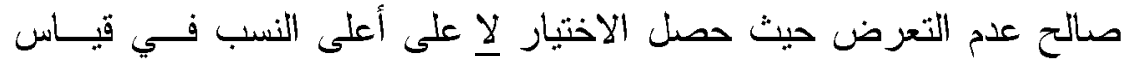

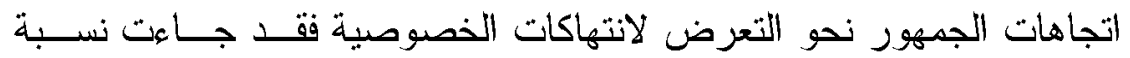
الإجابة بلا عن العبازة لقد تم تصويري / تصوير أحد أصدقائي أثناء تواجدنا

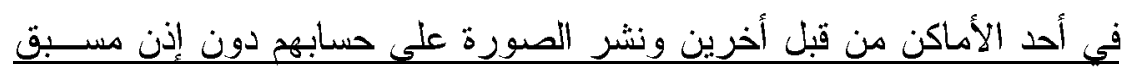

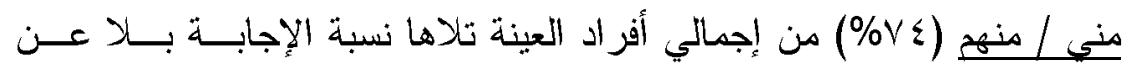

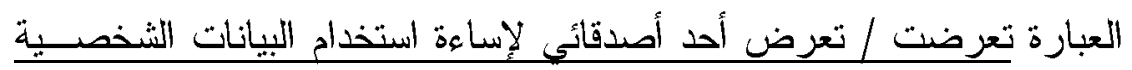

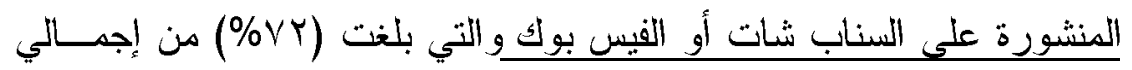

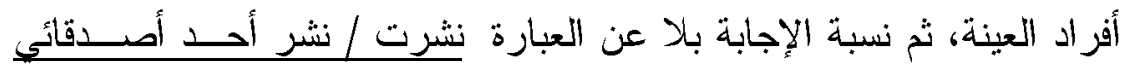


صور أو فيديو هات تسبيت لأذى أو حرج لنـا أو للآخـرين و التــي بلغــت

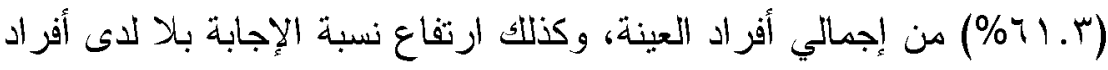

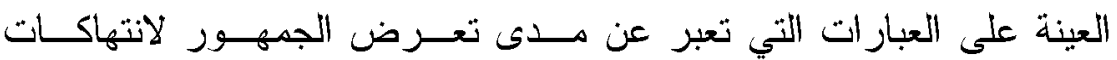

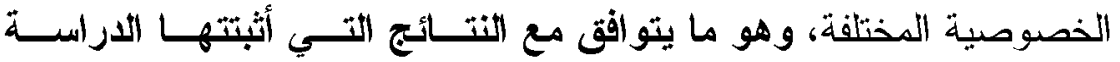
الراهنة حيث أكلات على وعي الجمهور بأهمية اتخاذ كافة إجراءات الأمسان أثناء التعامل مع مواقع التواصل الاجتماعي. أكدت نتائج الدراسة على حرص أفراد العينة على كتابة أســمائهج الحقيقيــة

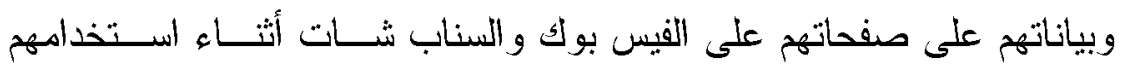

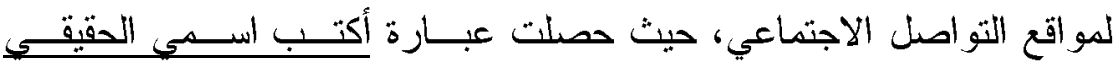

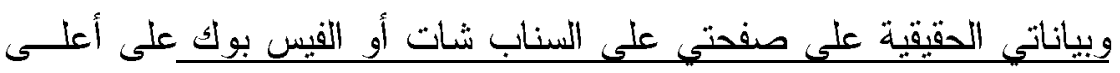
نسبة في المو افقة الثنديدة والتي بلغت (ع ب\%) من إجمالي العينة.

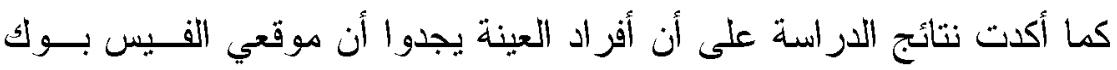

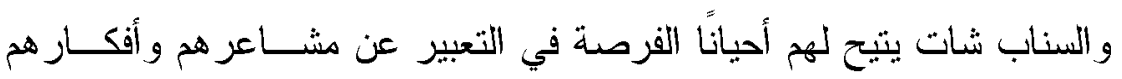

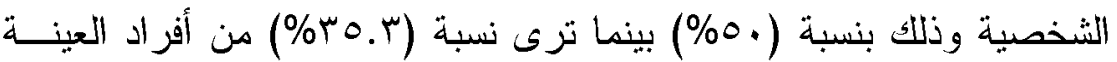
أنها تتيحها لهم بشكل دائم وذلك في الإجابة على عبازة يتيح لي السناب شات لئل أو الفيس بوك التعبير عن مشاعري و أفكارب الثخصية بشكل كبير أوضحت نتائج الدراسة أيضًا مواظبة نسبة من أفــر اد العينــة فــي بعـض الأحيان على نشر يومياتهر ومشاركة حياتهز الثخصية مع المضافين عنــدهر

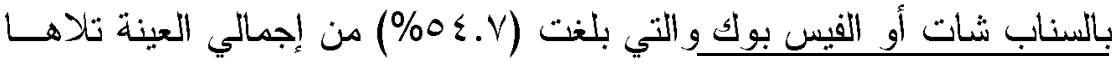

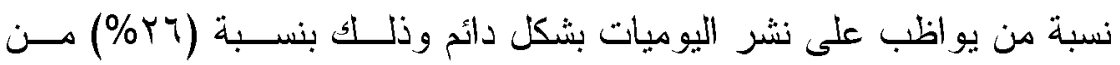
إجمالي العينة. 
أكدت نتائج الدر اسة أيضًا على عدم المتابعة المســتمرة ليوميـات مثـــاهير

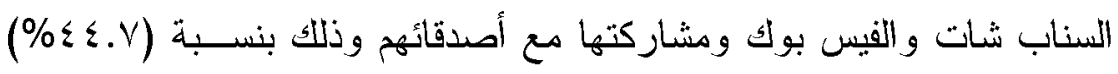

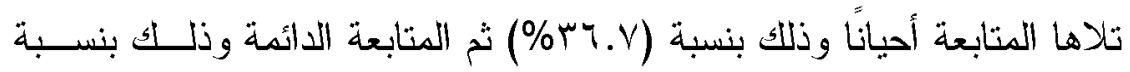

$$
\text { (\%) من إجمالي أفراد العينة. (A.V) }
$$

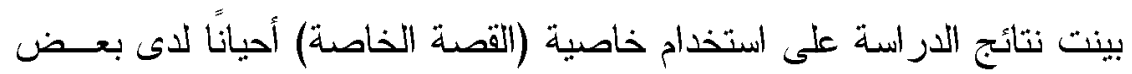

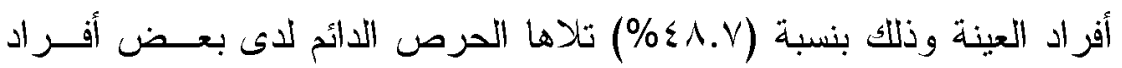

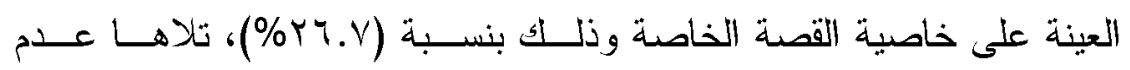
استخدام الخاصية لدى نسبة (Y.Y.Y. ) من إجمالي أفراد العينة.

عدم وجود علاقة دالة إحصائياً بين نوع المبحوثين (ذكر -أنتـى) وطبيعـة

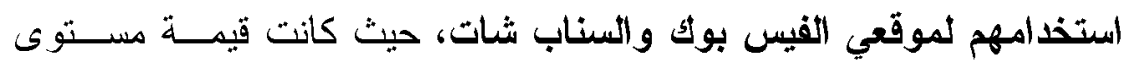

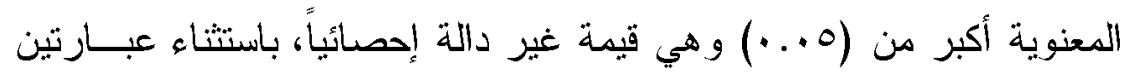

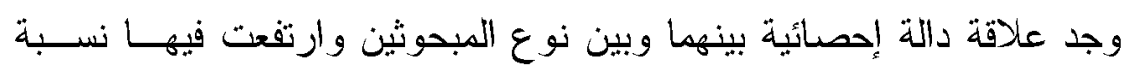
الإناث عن الأكور في الاستخدام المنتظم و الأئم وهما:

يتيح لي السناب شات أو الفيس بوك التعبير عن مشاعرب و أفكاري الثخصية بشــل

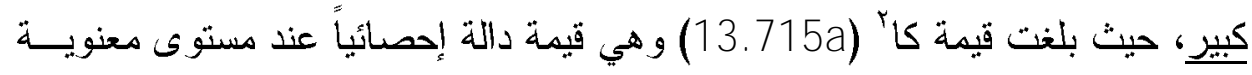

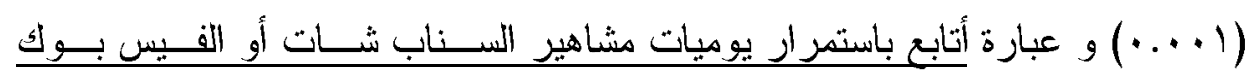

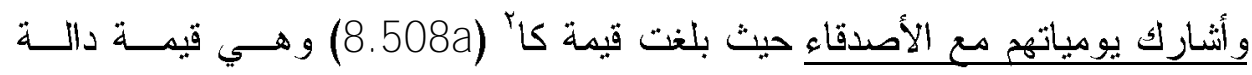
إحصائياً عند مستوى معنوية (ع ( ...).

ارتفاع إدر الك الجمهور بأسباب انتهاك الخصوصية عبر موقعي الفيس بــوك

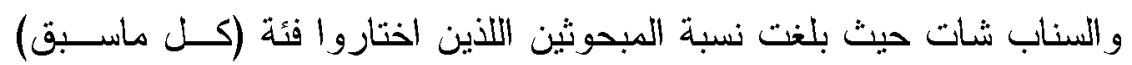

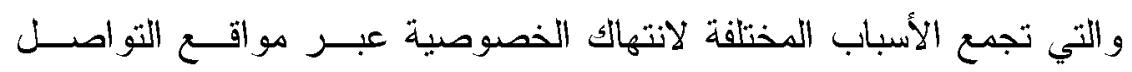

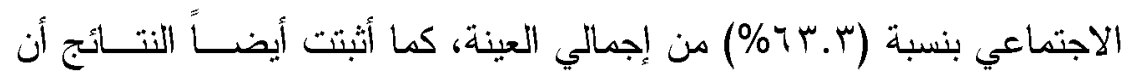


بقية أفر اد العينة على وعي كامل بسبب من أسباب انتهاك الخصوصية، حيث جاءت عدم معرفة الثخص بقو اعد وإجر اءات الأمان المختلفة الو اجب اتباعها عند استخدام السناب شات / الفيس بوك في المركز الثاني كسبب من أســباب

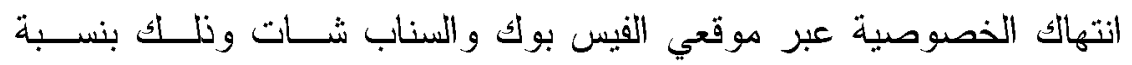
(\%) Y.V) مشاركة تفاصيل حياته الشخصية بشكل يومي على السناب شـات / الفـيس

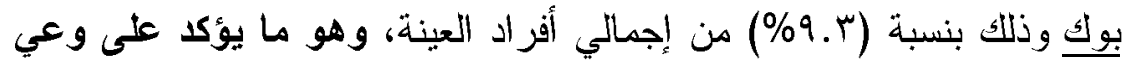

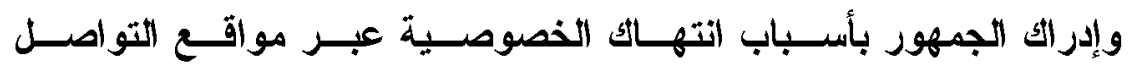

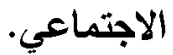

عدم وجود علاقة دالة إحصائًاً بين جنسية المبحوثين (مصري-غير مصري)

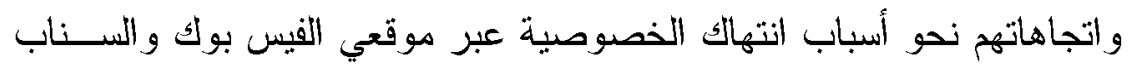

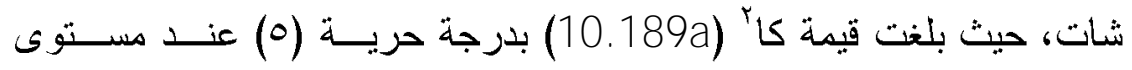

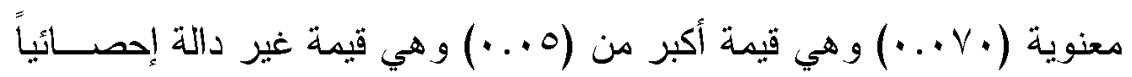
وهو ما يدل على عدم تأثير متغير جنسية المبحوثين على اتجاهـاتهم نحسو أسباب انتهاك الخصوصية عبر مواقع التواصل الاجتماعي. أكلت نتائج الاراسة على ارتفاع نسبة تأييد الجمهور للعبارات التــي تعبـر عن المخاطر التي يتسبب فيها انتهاك الخصوصية عبر موقعي الفيس بــوك والسناب شنات واتجاهاتهم نحوها، حيث جاءت نسبة تأييد الجمهــور لعبــارة

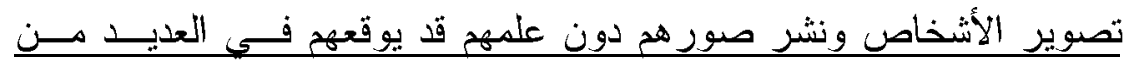

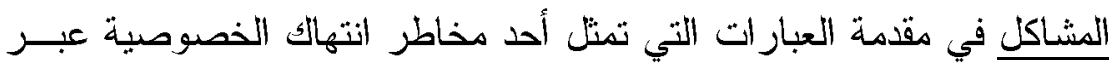

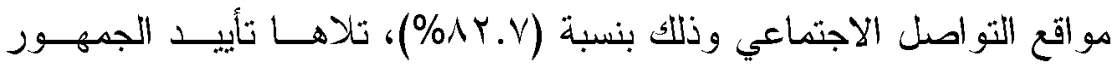

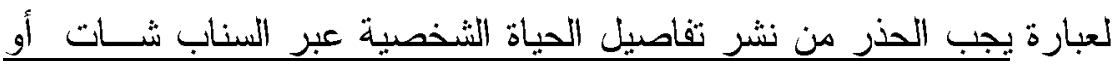

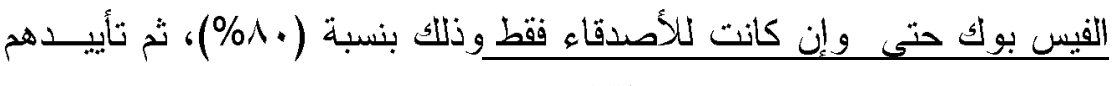


لعبارة نشر معلومات شخصية عن بعض الأشخاص على الســناب شـات أو

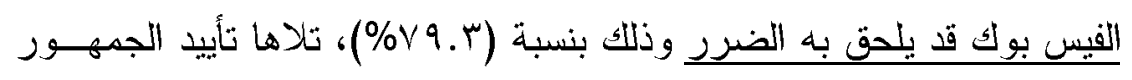
لعبارة تنشر عدد من صفحات السناب شات / الفيس بوك العديد من الشائعات

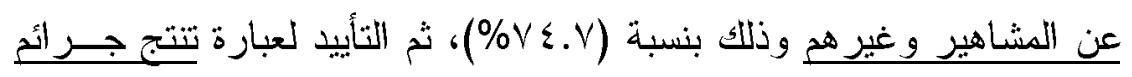

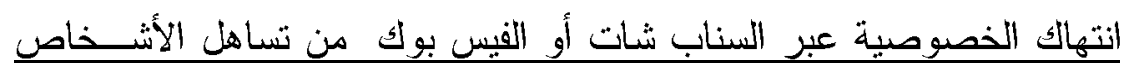

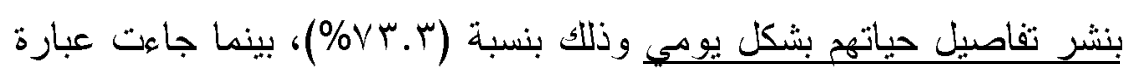

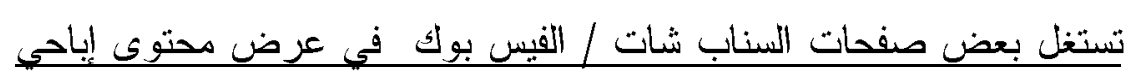

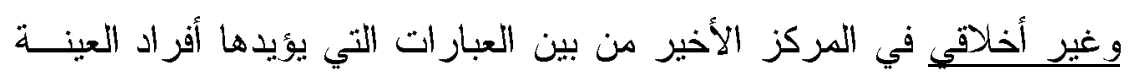

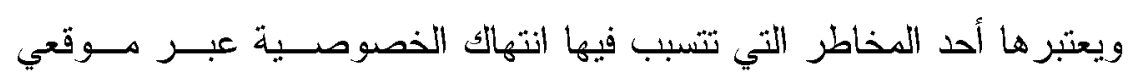

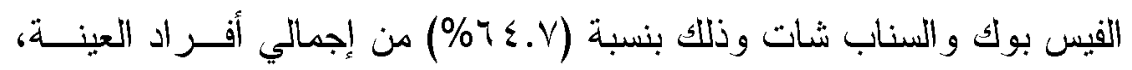

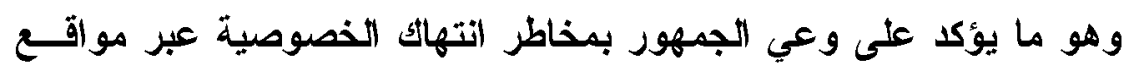
التواصل الاجتماعي.

أكلات نتائج الدراسة على تفوق الاتجاهات الإيجابية للجمهور نحسـو مــوقعي السناب شات والفيس بوك وذلك على النحو الآتي: - حصلت العبارة يعد السناب شات / الفيس بوك مدخلًا خصبًا لانتهـاك الخصوصــية

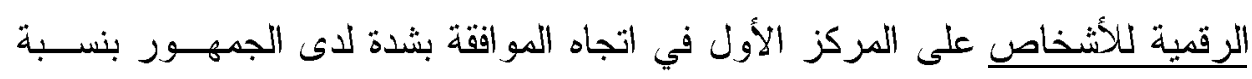

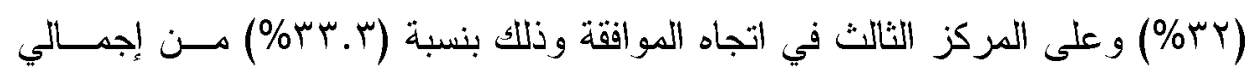
العبنة. - حصلت العبارة يعد تطبيق السناب شات / الفيس بــوك التطبيـق الأنســب لنشــر

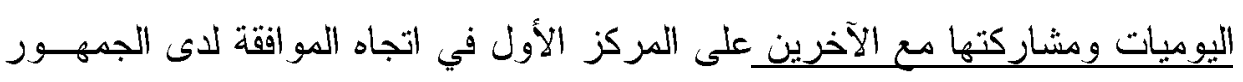

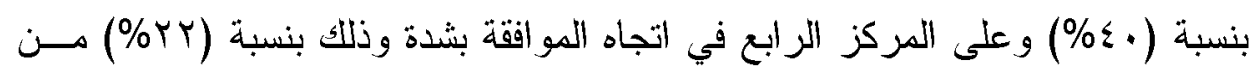
إجمالي العينة. 
- بينما حصلت العبارة يوفر تطبيق السناب شــات / الفـيس بـــوك الأمـــان الكامـل

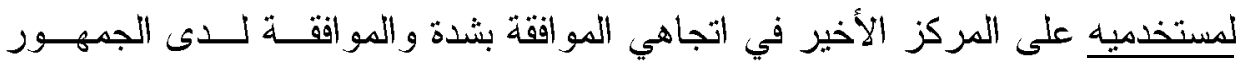

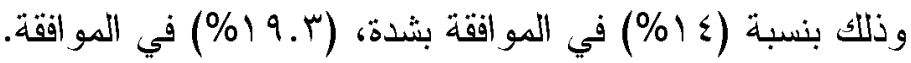

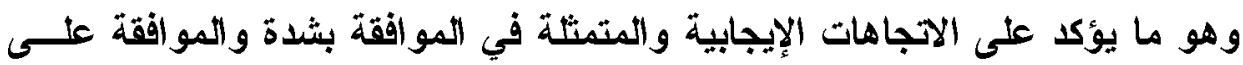

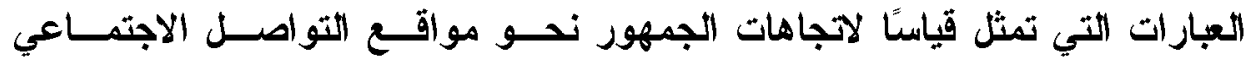
و المتمثلة في السناب شات والفيس بوكث.

تعرض نسبة قليلة من أفز اد العينة لموقف من مو اقف انتهاكات الخصوصـية على موقعي السناب شات و القيس بوك وذلك بنسبة (ب.بr\%\%) هـن إجمــالي العينة.

أن أكثر أفراد العينة ممن أجابوا بنعم لتعرضهم لمواقف انتهاكات الخصوصية

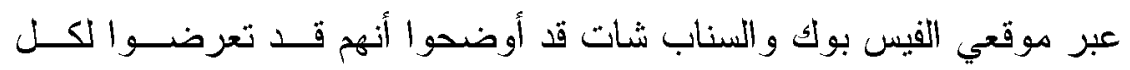

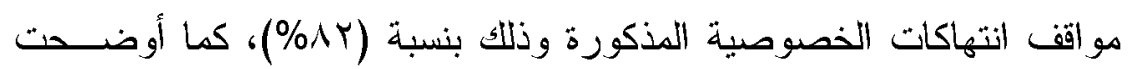
بقية النسب تعرض المبحوثين لموقق من مواقف انتهاك الخصوصبة، بينــا

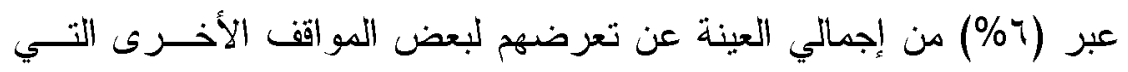

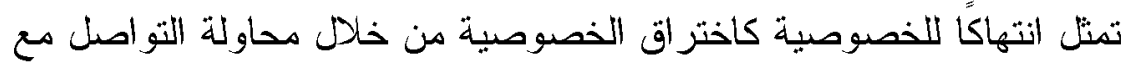
أسرة الثخص و المضاقين على صفحته، أخذ منشور بدون إذنها، وهو ما يؤكد

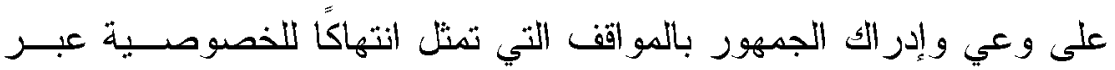

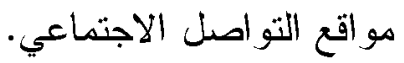

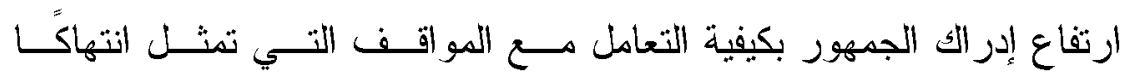

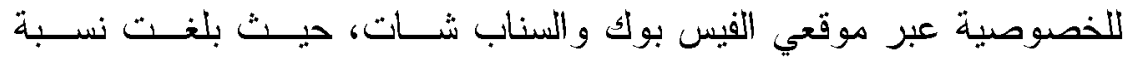
الدبحوثين الذين اختاروا فئة (كل ماسبق) والتي تجمع بـين ردود الأفحسال

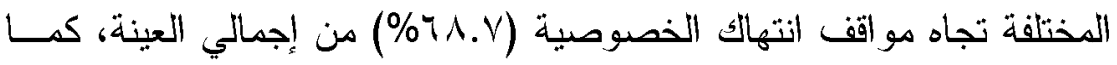




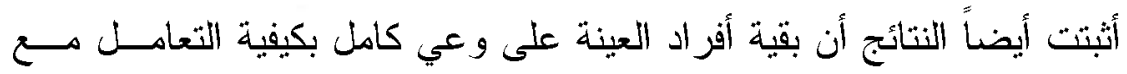
هذه المو اقف، كما أوضحت نسبة(V. . \% من إجمالي العينة عن عدم إضافتها

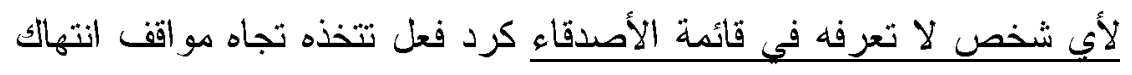

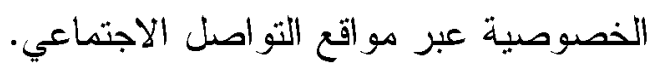

بينت نتائج الار اسة وعي الجمهور بأسباب استمر ار انتهاك الخصوصية عبـر موقعي الفيس بوك و السناب شات حيث بلغت نسبة المبحوثين الذين اختـاروا

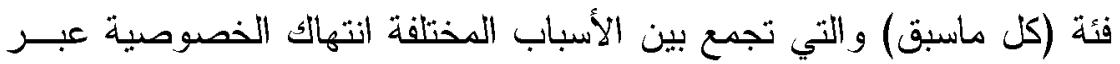

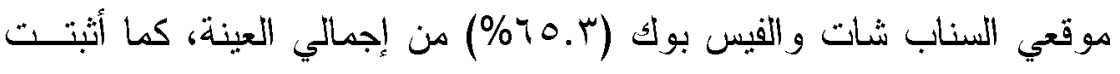
أيضاً النتائج أن بقية أفراد العينة على وعي كامل بسبب من أسباب اســتمرار انتهالك الخصوصبة عبر مواقع التواصل الاجتماعي.

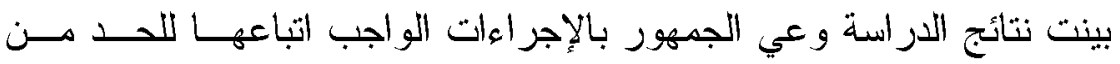
انتهاك الخصوصية عبر موقعي الفيس بوك و السناب شات حيث بلغت نســبة

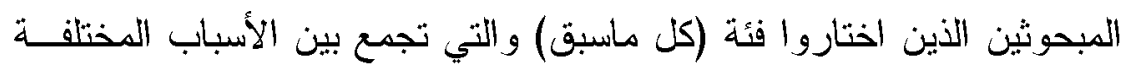

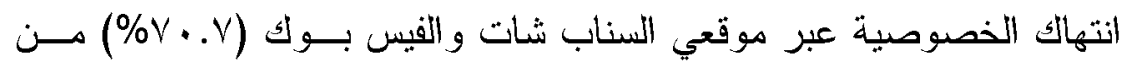

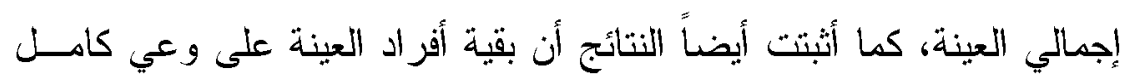
بإجز اء من إجراءات الحد من انتهاك الخصوصية عبـر مواقــع التواصــل الاجتماعي.

لمعرفة الفروق بين الجنسيات المختلفة للمبحوثين و اتجاهــاتهم نحــو انتهــاك One الخصوصية عبر تطبيقي السناب شات / الفيس بوك تم إجر اء اختبـار Way Anova الاتجاه نحو ردود الأفعال تجاه الموقف/ المواقف التي تمثل انتهاك الخصوصية عبـر تطبيقي السناب شنات / الفيس بــوثى : عدم وجود فروق دالة إحصائياً بــين جنسـية 
المبحوثين و اتجاهاتهم نحو ردود أفعالهم تجاه الموقف / المو اقف التي تمثـلـ انتهــاك للخصوصية عبر تطبيقي السناب شات / الفيس بوك وهو ما توضحه قيمسـة مســتوى المعنوية و التي جاءت (VVIT. . ) و هي قيمة غير دالة إعصائياً.

الاتجاه نحو أسباب استمرار انتهايك الخصوصية عبر تطبيقي السناب شات / الفيس

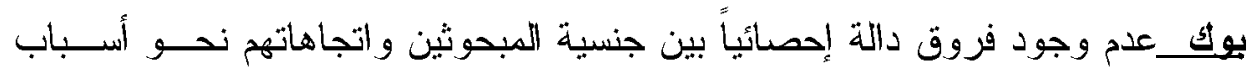

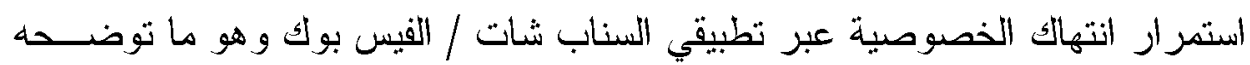
قيمة مستوى المعنوية والتي جاءت ( • (9 . ·) وهي قيمة غير دالة إحصائياً. الاتجاه نحو الإجر اءات الواجب اتباعها للح من انتهاك الخصوصبة عبـر تطبيقـي

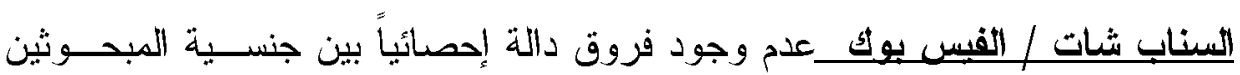
و اتجاهاتهم نحو الإجر اءات الواجب اتباعها للحد من انتهاك الخصوصية عبر تطبيةـي

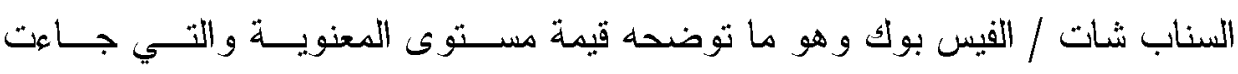

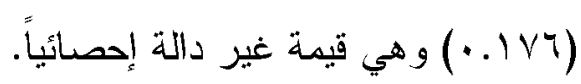

\section{توصيات الدراسة:}

ومن خلال ما سبق توصي الدر اسة بالآتي: 1 - سن قو انين ومو اثيق إعلامية جديدة تتناسب مع ما وصلت إليه وســائل الإعــلام الجديد من تطور.

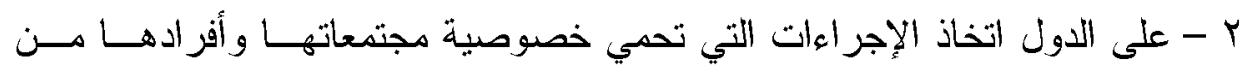

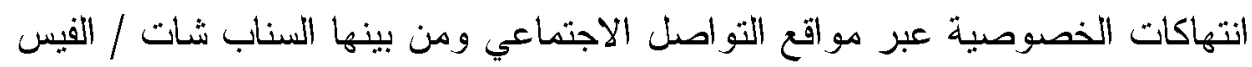
بوك. 
ب - العمل على تكثيف الحملات الإعلامية التي تهدف إلى التعريــف بالخصوصــية الرقمية وسبل مواجهة استمرار انتهاكات الخصوصية عبر مواقع التو اصل الاجتماعي ومن بينها الفيس بوك و السناب شات.

\section{قائمة المراجع :}

\section{أولاًا : المراجع العريبة}

1. أحمد بن مرسلي: " هناهج البحث العلمي في علوم الإعــلام و الاتصــال "، ديــوان

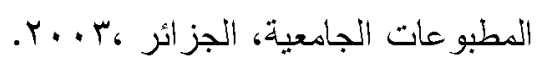

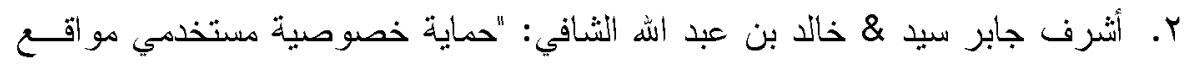

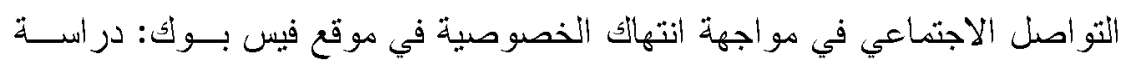

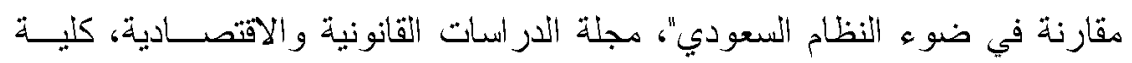

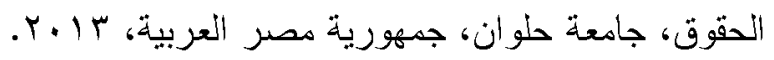
r. أمجد عمر عصفوري: " الثباب الأردني و انتهالك خصوصية الآخـرين باســتخدام شبكات التتو اصل الاجتماعي و التطبيقات الرقبية" مجلة أنساق، دار نشر جامعة قطر ،

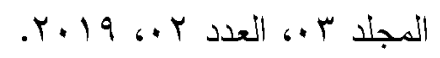

؛. إيان كريب: ترجمة محمد حسين غلوم، مر اجعة محمد عصفور : النظرية الاجتماعية

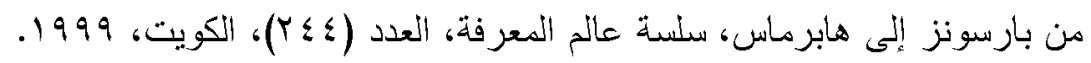

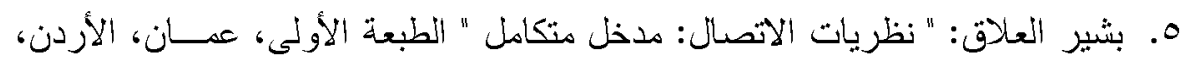

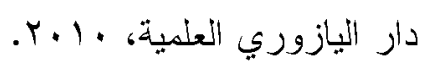

צ. خلفان الناصري: " هدى تأثثير شبكات التو اصل الاجتماعي في الحقوق الرقمية لدى

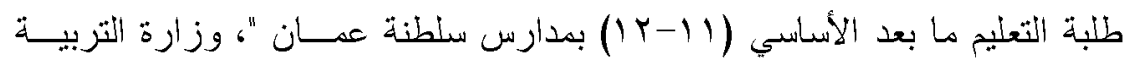

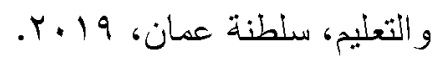


V. ر رائد محمد النمر : " حماية خصوصية مستخدمي مواقع التو اصل الاجتماعي علىى

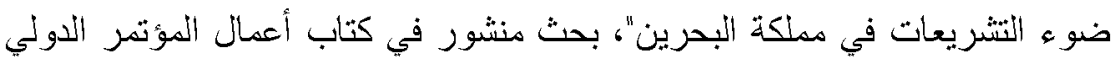

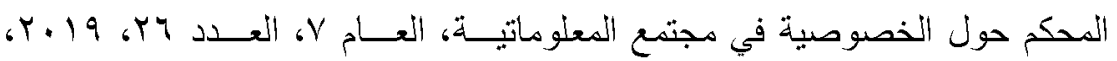
طر ابلس، لبنان. A. سالي سعد جودة إبر اهيم: دور المعلوماتية في التسويق السياحي لمصر الفيس بـوك

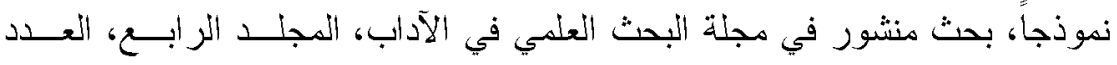

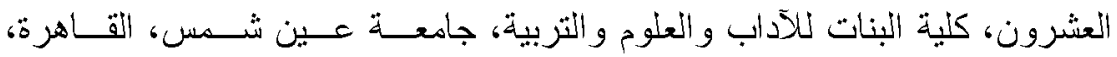

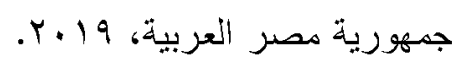

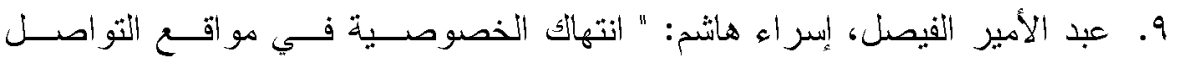

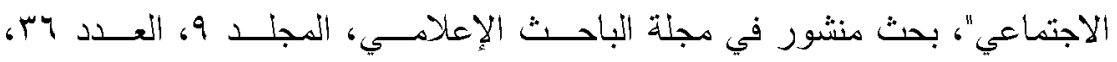
.$Y \cdot Y$ • (. عبد الباسط عبد المعطي: في النظرية المعاصرة لعلم الاجتماع، ب.د.ن، القـاهرة، $. r . .1$

ا1 (ـبد الحليم موسى، مصطفى عوض: " دور مواقع التو اصل الاجتماعي في انتهـاك

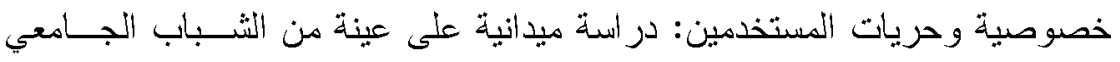

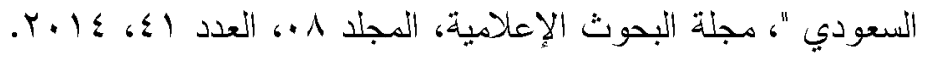

r ا. عبد النبي الطيب، فاطمة الزهراء: اتجاهات الثباب العوداني نحو استغلال وســائل

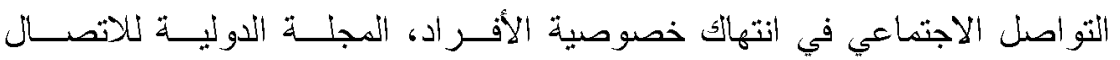

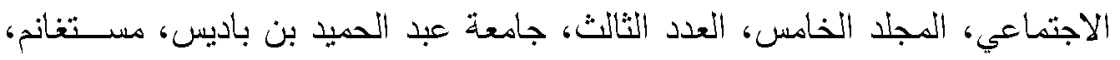

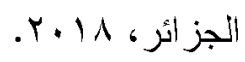

با ا.عبير محمد، سماح عيد: " إدمان الطلاب على استخدام مواقع التواصل الاجتمـاعي

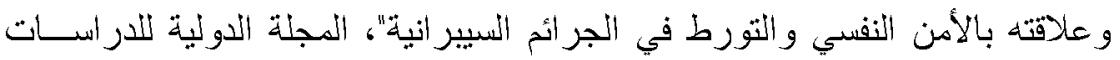

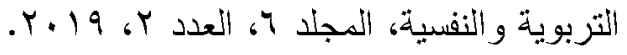




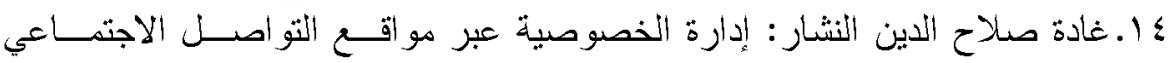

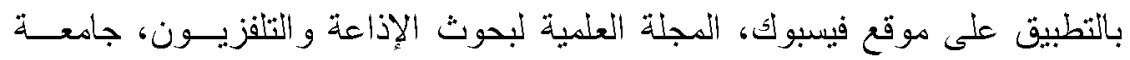

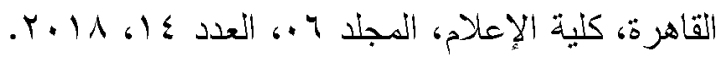

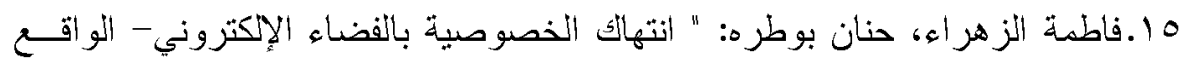

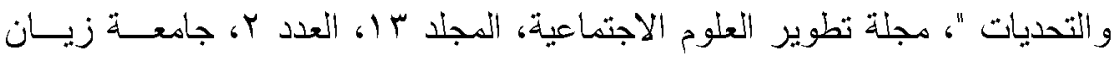

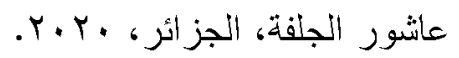

17 ا.مـارك بالنافاز ، وآخرون، ترجمة: عاطف حطيبة، مر اجعة: منال أبـو الحسـن: "

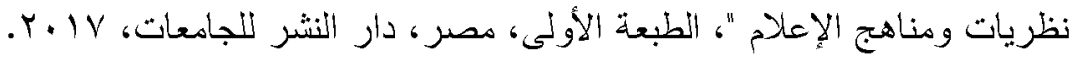
IV ا. محمد سامي: " اعتماد المر اهقين على الصحف الإلكترونيــة وشـبكات التو اصـل الاجتماعي ودورها في توعيتهم بمخاطر انتهاتك الخصوصية على شبكة الإنترنت "،

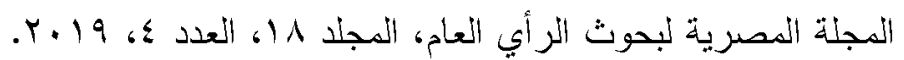

11 ا.محمد عبد الحمبد: " الاتصـال و الإعلام على شبكات الإنترنــت " الطبعـة الثالتهـة،

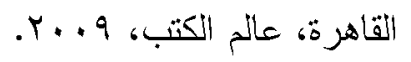

9 ا ـمحمود اسماعبل: " مبادئ علم الاتصال ونظريات التأثثر"، الطبعة الأولى، التاهرة،

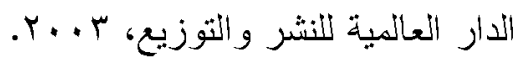

•Y.مصطفى علي سيد : " الاتجاهات الحديثة لنظرية الاستخدامات و الاشباعات"، المجلة

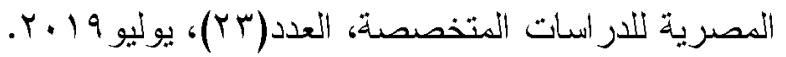

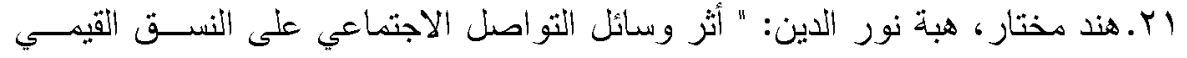

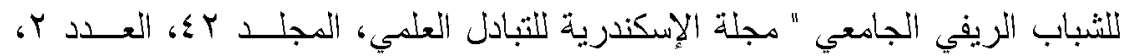

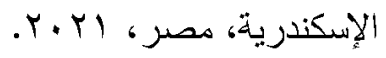


ثانباً: : المراجع الأجنبية

1. Grishma R.Pardeshi. "A Critical Review of Detection of Privacy Violation in Online Social Network". International Research Journal of Engineeringand Technology (IRJET), 2016, Vol.03, Issue.12.

2. Hiremath Veerabasayya Rudrayya: Uses and Gratification of Internet among College Students: A Study in Karnataka State, Doctor of Philosophy in Communication and Journalism, University of Mysore, Karnataka, India, March 2013.

3. Hongliang Chen, Christopher E. Beaudoin, and Traci Hong ، Protecting Oneself Online: The Effects of Negative Privacy Experiences, on Privacy Protective Behaviors, Journalism \& Mass Communication Quarterly, 2016, Vol. 93(2).

4. Katharine Sarikakis \& Lisa Winter. "Social Media Users' Legal Consciousness about Privacy". Social Media \& Society, 2017.

5. Madan Lal Bhasin., " Challenge of guarding online privacy: role of privacy seals, government regulations and technological solutions", Socìal'no-ekonomičnì Problemì ì Deržava, 15 (02), 2016.

\section{تُالثًا: مراجيع الاتترنت}

أر رائد محمد فليح النمر (: " حماية خصوصية مستخدمي مواقع التواصل الاجتماعي

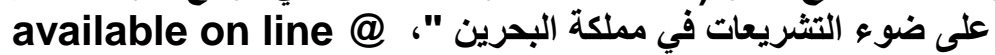
https://cutt.us/NW8z9 , access on 20-07-2021

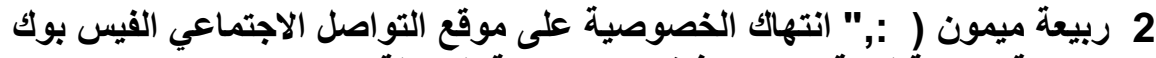

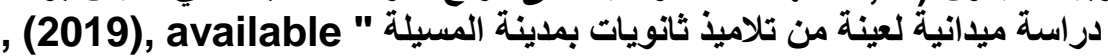
on line @ http://dspace.univmsila.dz:8080//xmlui/handle/123456789/17130, access on 29-06-2021. 
3 مركز القرار للاراسات الإعلامية ( : " مشاهير ““سناب شات" في السعودية

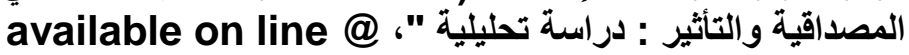

-5-2021. rqhttps://alqarar.sa/1410 , access on

4 محمد عيد عبد الهادي القحطاني ( :," حماية الخصوصية الثخصية لمستخدمي

مواقع التواصل الاجتماعي " @ (2015), available on line ) ,

https://repository.nauss.edu.sa/handle/123456789/62524 -06-2021. $r q$, access on

5 مهند حميد (" مظاهر إدمان الشباب على استخدامات وسائل الإعلام الجديد"، , , (12) , Journal of Al-Frahedis Arts, Vol (12), Issue (42), Part I, 2020, pp (463-488), available on line @

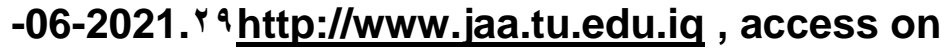

6 ) kaspersky report , "The true value of digital privacy: are consumers selling themselves short?", available on line @ https://www.kaspersky.com/blog/privacyreport-2019/, access on 15-07-2021. 7 ) The Kaspersky Lab Global Privacy Report(2019)." The true value of digital privacy: are consumers selling themselves short?", available on line@ https://www.kaspersky.com/blog/privacy-report-2019/ , access on 29-5-2021. 